Portland State University

PDXScholar

6-23-1997

\title{
An Ethnography of Classroom Interaction in Hoshuko: A Case Study of the Japanese Supplementary School Classroom
}

Nobuko Higashi

Portland State University

Follow this and additional works at: https://pdxscholar.library.pdx.edu/open_access_etds

Part of the Speech and Rhetorical Studies Commons

Let us know how access to this document benefits you.

Recommended Citation

Higashi, Nobuko, "An Ethnography of Classroom Interaction in Hoshuko: A Case Study of the Japanese Supplementary School Classroom" (1997). Dissertations and Theses. Paper 5346.

https://doi.org/10.15760/etd.7219

This Thesis is brought to you for free and open access. It has been accepted for inclusion in Dissertations and Theses by an authorized administrator of PDXScholar. Please contact us if we can make this document more accessible: pdxscholar@pdx.edu. 
The abstract and thesis of Nobuko Higashi for the Master of Arts in Speech

Communication were presented June 23, 1997, and accepted by the thesis committee and the department.

COMMITTEE APPROVALS:

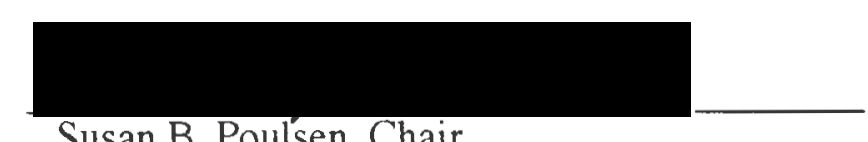

Susan B. Poulsen, Chair
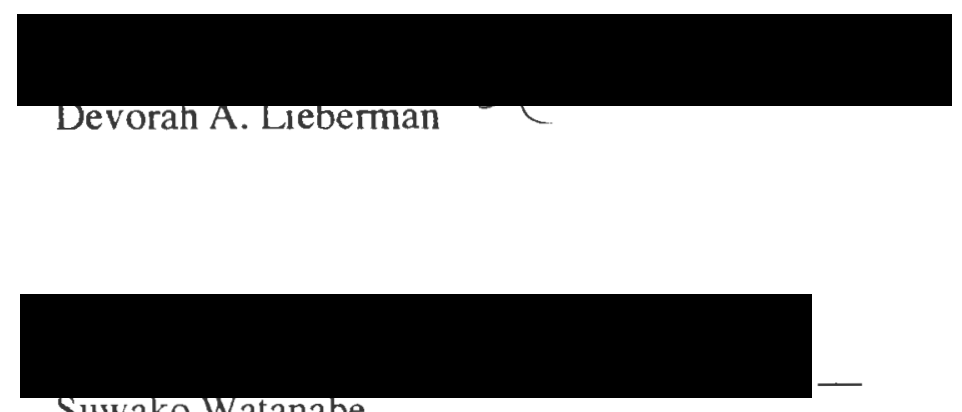

Suwako Watanabe

Representative of the Office of Graduate Studies

DEPARTMENT APPROVAL:

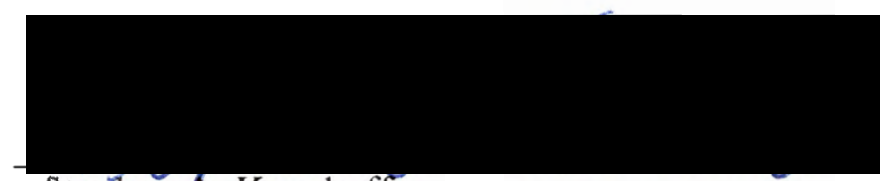

Stephen A. Kosokoff

Department of Speech Communication

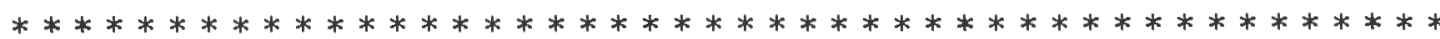

\section{ACCEPTED FOR PORTLAND STATE UNIVERSITY BY THE LIBRARY}

by

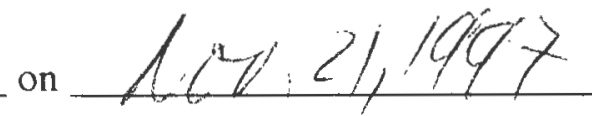




\begin{abstract}
An abstract of the thesis of Nobuko Higashi for the Master of Arts in Speech Communication presented June 23, 1997.
\end{abstract}

Title: An Ethnography of Classroom Interaction in Hoshuko: A Case Study of the Japanese Supplementary School Classroom

Based on the Ethnography of Communication perspective, this study explores the patterns and norms for interaction in a hoshuko classroom setting, as well as the participants' socially-constructed reality of hoshuko schooling. The focus of this study is the classroom communication patterns of the participants of a first grade hoshuko classroom in the U.S.

Hoshuko, Japanese supplementary school, is one type of school for overseas Japanese children which they attend on weekends or after regular, weekday school hours at local schools in their host country. The school is "supplementary" in the sense that the students learn subjects they would have learned if they were attending school in Japan. Thus, hoshuko students move between two educational systems -the host country (in this case, the U. S.) and Japanese -- that are likely to have different sets of cultural norms and values that they must learn.

Data were collected through observations of a first-grade hoshuko classroom, from cultural artifacts, and through interviews with the classroom teacher, some of the students, and their parents during a two-year field study.

Three key speech events were analyzed: kiritsu-rei, (Students) speak about their week, and practice Kanji. Results revealed that each activity in this hoshuko classroom had a certain set of norms that were set by the teacher, such as the 
"Japanese only" norm. Students were observed enacting norms with growing competency and were able, in the interviews, to articulate key norms. Also, the participants in this classroom setting interacted with each other according to the primary "hidden curriculum" (Jackson, 1968) of the class activities, which was "to enact the activities as close in form as possible to the ones that are enacted in schools in Japan." By having such "hidden curriculum," classroom activities served as ways for the teacher to transmit some of what she thought was important in Japanese norms and values. Children in this classroom were cooperative and active participants in receiving the transmitted values and fostering them through their participation in classroom interaction. Implications for Japanese teachers of returning hoshuko students were also discussed. 


\title{
AN ETHNOGRAPHY OF CLASSROOM INTERACTION IN HOSHUKO: \\ A CASE STUDY OF THE \\ JAPANESE SUPPLEMENTARY SCHOOL CLASSROOM
}

by

NOBUKO HIGASHI

A thesis submitted in partial fulfillment of the

requirements for the degree of

\author{
MASTERS OF ARTS \\ in \\ SPEECH COMMUNICATION
}

Portland State University

1997 
To all the overseas Japanese children and every other child in the world who always have something to give us adults

I also dedicate this thesis personally to my Grandma Sakae Higashi, who passed away during my stay in the U.S. , but somehow helped me in spirit to fulfill my dream. 


\section{ACKNOWLEDGMENTS}

I would like to take this opportunity to express my appreciation and gratitude to those who offered me support and encouragement in completing this thesis. I especially want to give my deepest appreciation to Dr. Susan Poulsen, the academic adviser and chairperson for my thesis. She spent many hours teaching, encouraging, supporting, and comforting me. I am grateful to Dr. Devorah Lieberman for her enthusiasm, cultural sensitivity in teaching, and for her valuable advice which helped shape the course of my study from the beginning. I am thankful to Dr. Suwako Watanabe for her kind words and encouragement. Her guidance has been instrumental in completing in the field study of the Japanese community. Dr. Watanabe also spent countless hours assisting me to work with my ideas in Japanese and in English. I am also grateful to all the students, the faculty, and the staff of the Speech Communication Department "community" for providing me with a great academic and personal experience. I would also like to give a special thanks to Ms. Linda Dunn for allowing me to observe her class and interview her. My field study in her room gave me insights to a traditional U. S. classroom.

In Japan, I would like to thank Dr. Teruyuki Kume, Dr. Gunei Sato, and people of Kaigai Shijo Kyoiku Shinko Zaidan[Japanese Overseas Educational Services] (both in Tokyo and Osaka) for providing valuable information about overseas Japanese children.

The completion of this thesis could not have been accomplished without the involvement of the hoshuko community. The hoshuko community kindly opened their arms to me and my fieldwork.

Finally, I would like to express my deepest gratitude to my family who have provided me assistance, encouragement, and love throughout my academic years in 
the U. S., to Adams family (my "family" in the U. S.), for coming to emotional supports when I needed them most, and to Shuichi Morikawa, for letting me be myself, spread my wings, and pursue my dream. 
TABLE OF CONTENTS

PAGE

ACKNOWLEDGMENTS $\quad \ldots \ldots \ldots \ldots \ldots \ldots \ldots \ldots \ldots \ldots \ldots \ldots$

LIST OF FIGURES $\quad \ldots \ldots \ldots \ldots \ldots \ldots \ldots \ldots \ldots \ldots \ldots \ldots$ vi

CHAPTER

I INTRODUCTION $\ldots \ldots \ldots \ldots \ldots \ldots \ldots \ldots \ldots \ldots$. 1

Research Purpose $\quad \ldots \ldots \ldots \ldots \ldots \ldots \ldots \ldots . \ldots \ldots$

Definition of Key Concepts $\ldots \ldots \ldots \ldots \ldots \ldots \ldots$

Significance of The Study $\quad \ldots \ldots \ldots \ldots \ldots \ldots \ldots, 4$

The Research Questions $\quad \ldots \ldots \ldots \ldots \ldots \ldots \ldots .6$

Overview of the Study $\quad \ldots \ldots \ldots \ldots \ldots \ldots \ldots 6$

II REVIEW OF THE LITERATURE $\ldots \ldots \ldots \ldots \ldots \ldots, 7$

Classroom Interaction: Ethnography of

Communication Approach $\quad \ldots \ldots \ldots \ldots \ldots, 7$

Application of The Ethnography of Communication:

Classroom Interaction Research $\ldots \ldots \ldots \ldots \ldots 10$

Historic and Cultural Background of The Research Field. . 14

Research Focusing on The Research Field $\ldots \ldots \ldots, 16$

Summary $\quad \ldots \ldots \ldots \ldots \ldots \ldots \ldots \ldots \ldots \ldots \ldots$

III METHODOLOGY $\ldots \ldots \ldots \ldots \ldots \ldots \ldots \ldots \ldots, 22$

Qualitative Research Methods $\quad \ldots \ldots \ldots \ldots \ldots .22$

The Ethnography of Communication $\quad \ldots \ldots \ldots \ldots 24$

Research Process $\quad \ldots \ldots \ldots \ldots \ldots \ldots \ldots \ldots . \ldots 27$

Reliability and Validity $\quad \ldots \ldots \ldots \ldots \ldots \ldots .34$

Transcription and Translation $\quad \ldots \ldots \ldots \ldots \ldots . .39$ 
Pilot Study $\quad \ldots \ldots \ldots \ldots \ldots \ldots \ldots \ldots \ldots \ldots \ldots \ldots \ldots \ldots$

Data Analysis $\quad \ldots \ldots \ldots \ldots \ldots \ldots \ldots \ldots, 43$

IV ANALYSIS OF DATA $\quad \ldots \ldots \ldots \ldots \ldots \ldots \ldots, 45$

Description of The Research Field $\ldots \ldots \ldots \ldots \ldots, 45$

Analysis of JSS Hoshuko $\quad \ldots \ldots \ldots \ldots \ldots \ldots . . \ldots 7$

Speech Community $\ldots \ldots \ldots \ldots \ldots \ldots .48$

Speech Situation / Structure of JSS Day $\quad \ldots . \quad 51$

Structure of JSS Day/ The Students' View $\ldots . \quad 59$

Analysis of Selected Speech Events $\ldots \ldots \ldots \ldots \ldots \ldots 61$

1) kiritsu-rei [stand-up-and-bow] ........ 61

2) "(Students) speak about their week" ...... 65

3) practice $K a n j i \quad \ldots \ldots \ldots \ldots \ldots \ldots, 68$

Summary $\quad \ldots \ldots \ldots \ldots \ldots \ldots \ldots \ldots \ldots \ldots \ldots \ldots \ldots$

V DISCUSSION AND CONCLUSION $\ldots \ldots \ldots \ldots \ldots, 73$

Research Findings $\quad \ldots \ldots \ldots \ldots \ldots \ldots \ldots \ldots, 73$

The Three Speech Events: Norms and Functions .. 73

At the Classroom Level: Norms and Functions . . 81

"Hidden Curriculum"

and "Cultural Transmission" $\ldots \ldots \ldots .84$

Children's Ways of Speaking $\quad \ldots \ldots \ldots .87$

Perceived Purposes of the JSS $\quad \ldots \ldots \ldots .91$

Summary of Findings $\ldots \ldots \ldots \ldots \ldots \ldots \ldots \ldots, 93$

Study Limitations and Contributions $\quad \ldots \ldots \ldots .94$

Implications for Future Research $\quad \ldots \ldots \ldots \ldots \ldots .96$

Conclusion $\quad \ldots \ldots \ldots \ldots \ldots \ldots \ldots \ldots \ldots . \ldots 9$

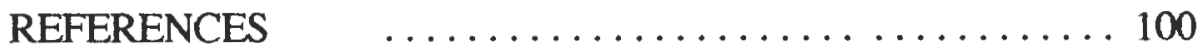




\section{APPENDICES}

A. Correspondence with the Research Site

Regarding Field Entry $\quad \ldots \ldots \ldots \ldots$. . . 109

B Informed Consent $\quad \ldots \ldots \ldots \ldots \ldots \ldots \ldots$

C. Correspondence with the Family of the Students

Regarding the Interview $\quad \ldots \ldots \ldots \ldots \ldots 125$

D Interview Guides $\quad \ldots \ldots \ldots \ldots \ldots \ldots \ldots$

E Diagram of School Setting $\ldots \ldots \ldots \ldots \ldots$ 


\section{LIST OF FIGURES}

FIGURE

PAGE

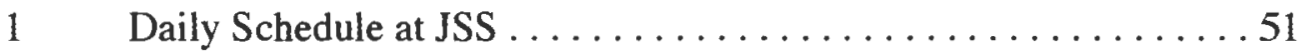

$2 \quad$ Speech Event Matrix $\ldots \ldots \ldots \ldots \ldots \ldots \ldots \ldots \ldots \ldots \ldots \ldots \ldots$ 


\section{CHAPTER I}

\section{INTRODUCTION}

Culture has a great impact on the way educational institutions operate as well as how people interact in those institutions. For example, what is considered appropriate behavior in U.S. classrooms may not be appropriate behavior in Japanese classrooms. This may be because the participants in each setting may have their own, culturally-based assumptions and expectations about classroom behavior. In fact, Anderson and Powell (1991) claim that "the entire educational system, together with the rules and procedures for effective classroom interaction reflects a cultural dictate" (p. 209).

Hoshuko, supplementary schools for overseas Japanese children, were established to provide "the education equal to that of the compulsory education system in Japan" (White, 1989, p. 53). They provide a unique educational, cultural context for their students. Most students attending hoshuko go to local schools or "international schools" in their host country on weekdays, and go to hoshuko on Saturdays or sometimes after school. Japanese teachers teach subjects in Japanese, using the same textbooks used in schools in Japan.

In an attempt to understand how the students of hoshuko interact with each other and with teachers in this culturally unique educational setting, this study examined their particular ways of communicating with each other from the ethnography of communication perspective. The focus in this study was a first grade hoshuko classroom in the Western U.S. 


\section{RESEARCH PURPOSE}

Due to Japan's economic and industrial advancement after World War II, the number of Japanese businesses that expanded their businesses overseas and sent their personnel abroad to staff international operations, has dramatically increased, especially since the 1960s. In 1994 there were 432,703 Japanese people living abroad, and this increase in number is attributed to the increase in the number of Japanese business personnel and their families (Sato, 1991b). Many of these families have underage children, and as the number of Japanese personnel increases, so does the number of overseas Japanese children who accompany their parents. Of the 432,703 Japanese living outside Japan, almost 50,000 of them were children. More than 19,000 overseas Japanese children live in North America ${ }^{1}$ alone (Ministry of Education, 1994). Hoshuko exists, for many of these Japanese children, as a place where they learn the school subjects in Japanese with their peers, many of whom will go back to Japan.

I am interested in researching communication patterns in the hoshuko classrooms in the U.S. because I believe that the participants of this particular setting, both teachers and students, are constantly influenced by two different cultures. On one hand, participants are influenced by Japanese culture through the interaction with each other as Japanese in the classroom and through the Japanese language they use during such interactions. On the other hand, they are influenced by the U. S. culture through the interaction with the U.S. people in and outside of the classroom setting and through the everyday life in the U.S. social system. I believe that the students' experience of attending U.S. local schools five days a week has a great influence on

\footnotetext{
1 Official statistical data of overseas Japanese children usually comes from the Ministry of Education, where they group the United States and Canada, and make one category. Thus some data for the U. S. alone was not available to the researcher.
} 
how those students make sense of "going to school" and "studying in the classroom." Several questions arise. What kind of communication patterns are exhibited in the hoshuko? What are the norms and functions behind such communication patterns? What do these communication patterns and their functions mean to the participants of the hoshuko classroom, especially the children?

The purpose of this study was to discover, describe, and analyze the characteristics of communication patterns that occur in the hoshuko classroom, as well as to understand the meaning that overseas Japanese children make out of these classroom experiences. This study explored the patterns of and norms for interaction in this particular setting as well as the participants' socially constructed reality of hoshuko schooling.

\section{DEFINITION OF KEY CONCEPTS}

The following terms are used in this study:

Overseas Japanese children (OJC).

Although the general and literal definition of overseas Japanese children (hereafter referred to as OJC) is "the children of Japanese families who are living outside of Japan," the term connotes that they are "expected to go back to Japan." In this study, I used the term to refer to Japanese children whose parent's work requires them to be reared in a foreign country, but who are expected to go back to Japan some time in the future. This definition thus excludes those children, both from international marriages or from traditional Japanese marriages, who have immigrated to the host country or who were born in the host country, and have no plans for living in Japan in the future. 


\section{$\underline{\text { Hoshuko }}$}

Hoshuko is an educational institution for OJC where academic subjects are taught in Japanese on Saturdays or after regular, weekday school hours (Ministry of Education, 1994); however, many hoshuko meet once a week on Saturdays. Many hoshuko have a total of forty to fifty school days during a school year, and teach two academic subjects each school day.

In the academic field in Japan, the term hoshuko is often used to differentiate from nihonjin-gakko [Japanese full-time school], another possible form of schooling for overseas Japanese children. Compared to nihonjin-gakko which usually provide all-day schooling throughout the week, hoshuko often becomes the place where students, who often attend separate local schools, have their rare opportunity to meet with their Japanese friends and study side by side the school subjects in Japanese.

Most of the Japanese teachers in hoshuko have lived in the host country for some time, but many hoshuko have at least one person -- usually the principal -- who is selected and sent from Japan to stay in the hoshuko for three years until the next principal arrives. Some hoshuko recognize the fact that they provide one of very few opportunities for many OJC to meet together in one place, and try to teach Japanese customs or "ways of living as a Japanese" (Ministry of Education, 1994, p. 14) along with academic subjects.

\section{SIGNIFICANCE OF THE STUDY}

This study helps to fill a research gap both in communication research and the studies of the specific cultural group under study -- overseas Japanese children (OJC). There are very few studies on OJC that focus on communication (Kume, 1991), and few look at the communication patterns among the children in a natural setting called 
the hoshuko classroom. Moreover, few researchers have conducted studies of hoshuko (Center for Education of Children Overseas, 1984), and thus little is known about hoshuko as an educational setting where cultural information is transmitted (Sato, 1991a). By taking an ethnographic approach, I investigated how OJC communicate, both verbally and nonverbally, in this specific classroom setting.

It is also timely to conduct a study of communication patterns in use among this particular cultural group. First, although "the issues of returning Japanese children (kikokushijo-mondai in Japanese)" have been discussed among educators and others in Japanese society for over two decades, there still seems to be a considerable gap between Japanese people's image of OJC and OJC's understanding of themselves (Sato, 1995). Second, it is also reported that "educational friction" (Sato, 1991b, p. 15) between the child(ren) and the teacher exists in U.S. classrooms where OJC attend on weekdays. This research will help the parents, educators, and other professionals, both in Japan and in the U. S, who want to have a deeper understanding of the features and functions of communication among OJC, and those who want to facilitate their learning.

Also, a review of some of the OJC-related literature suggested that previous studies had excluded children of international marriages, who also go to hoshuko. This may be one of very few studies that looks at this particular educational setting that was originally established exclusively for overseas Japanese children, but which, in the case of this study, includes children of international marriages. 


\section{RESEARCH QUESTIONS}

This study addresses the following research questions:

(1) What are the prominent recurring communication patterns in the hoshuko classroom?

(2) What are the norms and functions of those communication patterns?

(3) How do the students make sense of their schooling experience in hoshuko?

\section{OVERVIEW OF THE STUDY}

Chapter I has introduced the purpose of the study and its significance. Chapter II reviews the relevant literature on symbolic interactionism, the ethnography of communication as the theoretical framework and its application to classroom interaction research, historical and cultural information about overseas Japanese children and hoshuko and previous studies regarding overseas Japanese children and hoshuko. Methods are delineated in Chapter III including the framework of the study, research procedures, and issues that are closely related to the methodology of this study, such as validity and reliability, transcription and translation, as well as the pilot study. Chapter VI analyzes classroom interaction in Mrs. I's classroom, where the majority of fieldwork for this study took place. Finally, Chapter V discusses the research findings, study limitations and contributions, implications for future research, and the research conclusions. 


\section{CHAPTER II}

\section{REVIEW OF THE LITERATURE}

This chapter first discusses symbolic interactionism and the ethnography of communication as the theoretical framework of this study. Studies which have applied the ethnography of communication to classroom interaction research are also included. Secondly, the historical and cultural background of overseas Japanese children (OJC) and hoshuko are introduced. Finally, the relevant literature on communication studies on OJC, as well as on hoshuko are reviewed.

\section{CLASSROOM INTERACTION: ETHNOGRAPHY OF COMMUNICATION}

\section{APPROACH}

\section{Symbolic Interactionism}

This study is guided by the theoretical perspective of symbolic interactionism. George Herbert Mead is usually viewed as "the major source of the interactionist movement" (Littlejohn, 1992, p171); however the actual term "symbolic interactionism" was invented by Herbert Blumer and never used by Mead (Littlejohn, 1992, p171). Blumer (1969) argues that: (1) human beings act toward things on the basis of the meanings that the things have for them; (2) the meaning of such things is derived from, or arises out of, the social interaction that one has with one's fellows; and (3) these meanings are handled in, and modified through, an interpretative process used by the person in dealing with the things he or she encounters. From this perspective, social interaction, including classroom interaction, is a process of a construction of a reality in the particular situation, and in this case, teachers and their 
students construct meanings of their own actions. It becomes very important then, from this theoretical perspective, that the researcher appreciates and tries to "capture the meanings that permeate the culture as understood by the participant" (Woods, 1992, p. 354) by learning the symbols shared among the participants and situating the interaction in the context.

\section{The Ethnography of Communication: Theoretical Background}

This study is also guided by the descriptive-theoretical framework of the Ethnography of Communication. The ethnography of communication is a form of naturalistic inquiry whose purpose is to discover, describe, and analyze the interaction between language and culture. Compared to the terms "ethnography" and "ethnographic research" which generically refer to a form of social research that "[attempts] to describe the life of a group in its totality" (Sarret, 1984, p. 207), the ethnography of communication refers to the descriptive-theoretical framework that focuses on ways of communicating "in the conduct of social life" among a specific speech community (Bauman and Sherzer, 1975).

Originally introduced by Hymes as the ethnography of speaking in 1962, the ethnography of communication arose out of "the traditional anthropological concern with the interrelationships among language, culture, and society" (Bauman and Sherzer, 1975). While grammars deal with the structure of languages and ethnographies with the patterns and structure of culture or aspect(s) of culture, the ethnography of communication deals with "patterns and functions of speaking, patterns and functions that organize the use of language in the conduct of social life" (Bauman and Sherzer, 1975, p. 98). The fundamental premises of this mode of inquiry are that speaking is a cultural system, just like other systems of behaviors 
such as economics or politics, and that such systems are culturally relative (Hymes, 1972; Bauman and Sherzer, 1975; Bauman and Sherzer, 1974).

The goal of the ethnography of communication is "to discover, describe, and interpret patterns of speaking in particular speech communities" (Braithwaite, 1991, p. 146). Through the use of the SPEAKING mnemonic (Hymes, 1972; see more detailed discussion in pp. 26-27), ethnographers are able to formulate "descriptive theories of speaking as a cultural system or as a part of cultural systems" (Bauman and Sherzer, 1975, p. 98). Such theories, as Hymes (1972) contends, should be able to be compared with each other.

One of the important focuses of the ethnography of communication is the speech community where a certain way of communication is patterned and organized (Saville-Troike, 1989). Identification and delineation of the speech community provides a context in which distinctive ways of speaking are located (Braithwaite, 1991). Generally, the characteristics of the speech community may include: a high frequency of interaction by a group of people (Gumperz, 1962), shared rules of speaking and interpretation of speech performance (Hymes, 1972), shared attitudes and values regarding language forms and use (Labov, 1972), and shared sociocultural understanding and presuppositions with regard to speech (Sherzer, 1975). Bauman and Sherzer (1975) contend that "[speech] communities are defined in terms of overlapping and mutually complementary resources and rules for the production and interpretation of socially appropriate speech" (p. 113).

Among the members of a particular speech community, those who have the knowledge of such resources and rules are considered to possess "communicative competence" (Saville-Troike, 1989; Bauman and Sherzer, 1975). Communicative competence "involves knowing not only the language code, but also what to say to whom, and how to say it appropriately in any given situation" and "deals with the 
social and cultural knowledge speakers are presumed to have to enable them to use and interpret linguistic forms" (Saville-Troike, 1989, p. 21). Saville-Troike (1989) proceeds to claim that the communicative competence includes "everything involving the use of language and other communicative dimensions in particular social settings" (Saville-Troike, 1989, p.21).

Although many studies utilizing the ethnography of communication focus on ways of "talking," the ethnography of communication approach allows researchers to examine performance of communication, which may not necessarily center on language (Bauman and Sherzer, 1974). This characteristic was particularly important in my study since Japanese culture place stronger emphasis on non-verbal communication and less emphasis on verbal communication (Barnlund, 1989; Nishida, 1996; Javidi and Javidi, 1994).

\section{APPLICATION OF THE ETHNOGRAPHY OF COMMUNICATION: CLASSROOM INTERACTION RESEARCH}

While there is a considerable amount of research on classroom interaction taking an ethnographic approach (LeCompte and Preissle, 1993), the following two studies are particularly informative to this study as the researchers utilize the ethnography of communication framework to uncover varied and complex uses of communication in each of their classroom settings.

One is Heath's (1983) study on the communities and classrooms of people with distinctively different social backgrounds in the southern U. S. in the 1970 s. Historically, schools were experiencing "rapid multi-directional change" after school desegregation in the southern United States became a legislative mandate and "a fact of daily life" (Heath, 1983, p. 1). There were three culturally different groups of 
people in the region where she conducted her study: people of "Roadville," a Caucasian working-class community of families steeped for four generations in the life of the textile mills; people of "Trackton," an African-American working-class community whose older generation grew up farming the land, but whose current members worked in the mills; and "townspeople," mainstream African-Americans and Caucasians of the region who were school-oriented, and identified "with networks of voluntary associations and institutions whose activities [linked] their common interests across the region" (p. 1). African-American and Caucasian teachers, parents, and mill personnel were all concerned about "why students and teachers often could not understand each other, why questions were sometimes not answered, and why habitual ways of talking and listening did not always seem to work" (p. 2).

Heath (1983) tried to analyze the effect of preschool, home, and community environments on the learning of those language structures and uses which were needed in classroom and job settings. Based on the fieldwork in the three communities as well as in the classrooms, she concluded that: 1) the pattern of language use of the children of Roadville and Trackton before they went to school stood in sharp contrast to each other and to those of the children from townspeople families; 2) in schools, commercial establishments, and mills, mainstream language values and skills were the expected norm, and townspeople and their youngsters had the most familiarity with the communicative habits and preferences of these public institutions; and 3) individuals from communities such as Roadville and Trackton brought language values and skills different from the expected norm-based values and skills into such public institutions, and consequently had less access to work opportunities and education. Heath (1983) argued that "in Roadville and Trackton the different ways children learned to use language were dependent on the ways in which 
each community structured their families, defined the roles that community members could assume, and played out their concepts of childhood that guided socialization" (p. 11), and that the place of language in the cultural life of each social group was interdependent with the habits and values of behavior shared among members of that group. Heath (1983) contended that culture is "learned behavior," and that language habits are a part of that shared learning. Heath (1983) cautioned that any reader who tries to explain the community contrasts in the study on the basis of race will miss the central point, as they ignore "realities of the communication pattern of the region" ( $\mathrm{p}$. 3).

The other significant study of classroom interaction utilizing the ethnography of communication framework is Philips' (1983) study on the way Native American children in a reservation use English in the classroom. Philips (1983) conducted both a four-way comparative study of Caucasian and Native American first- and sixthgrade classrooms, and a community-focused study on the reservation where Native American children, observed in school, lived. This study was done in order "to explore in an open-ended fashion the way in which Warm Springs Native American's use of language was culturally distinctive" (Philips, 1983, p. 13). Through her fiveyear fieldwork she found that Native American students behaved differently from the Caucasian students in the classroom when they were listening, trying to get the floor, or taking turns, which often led the Caucasian teacher to believe that the Native American students were not comprehending. Philips (1983) argues that those differences are due primarily, although not entirely, to an incompatibility between Native American and Caucasian ways of organizing talk. For example, the Native American organization of interaction can be characterized "as maximizing the control that individual has over his or her own turn at talk, and as minimizing the control that a given individual has over the turns of others" (Philips, 1983, p. 115). This belief 
underlying turn-taking runs counter to the Caucasian organization of interaction which can be characterized as "involving greater exercise on the part of speakers and hearers of control over the turns of others" (Philips, 1983, p. 115). Philips (1983) found that "the expected talk" in the classroom is the Caucasian organization of interaction, and while Warm Springs Native American children "learn socially appropriate ways of conveying attention and regulating turns at talk in their homes and their community before they come to school" (Philips, 1983, P. 126), Native American children experience a culturally alien environment when they enter the school, and thus are defined as inadequate in their efforts to pay attention and to get the floor in the classroom.

Although these two studies deal with different ethnic groups, there are common themes that are shared between the two studies, which can also inform my study. One very important theme is that there are specific ways of speaking in the classroom setting, just like there are in larger cultures, at home, or at the workplace. The norms and values behind such ways of speaking are often a reflection of a section of the larger culture, but if a student belongs to a speech community which is not within the privileged section of the larger culture, that student's ways of communicating may be misinterpreted. It may also be too early to identify the speech community strictly along ethnic or racial lines since, as Heath (1983) pointed out, there may be an emergent speech community that goes across the different cultural backgrounds/contexts. 


\section{HISTORICAL AND CULTURAL BACKGROUND OF THE RESEARCH FIELD}

The historical change of overseas Japanese children as a group as well as the cultural and historical background of hoshuko needs to be explained in order to provide background information and to make the research purpose clear.

\section{Overseas Japanese Children: Past and Present}

After World War II, Japan started to rebuild its war-torn economy. Starting in the 1950s, Japan began to experience economic and industrial advancement, and by the 1960s Japan entered a "high economic growth" era (Sato, 1991b). Since then, for three decades, with a few ups and downs in its economy, Japan has established its place in the world economy.

The growth in number of overseas Japanese children (OJC) has been closely related to the economy and changes in the Japanese business world, for almost all OJC came to live outside Japan because of their parent's job. In 1971, there were about 8600 OJC; by the next year, the number exceeded 10,000. In 1978, over 20,000 OJC lived outside Japan and by 1981, the number exceeded 30,000.

In the late 1980 's, a strong yen created a favorable exchange rate that furthered Japanese businesses' expansion overseas. Consequently, the number of OJC continued to grow as well, and the number exceeded 40,000 by 1987 , and came close to 50,000 by 1990 (Sato, 1991b) Today, the number of OJC remains close to 50,000 , despite the fact that Japan has been experiencing a recession for a couple of years. 2

2 As of 1994, the number of overseas Japanese children declined for the tirst time since 1971, but still remained close to $50,000(49,397)$ (Japanese Ministry of Education, 1994). 


\section{Hoshuko: Past and Present}

The educational institutions established specifically for OJC, including hoshuko, were established by the effort of the Japanese business community, in order to "give education to the children of the Japanese people overseas" (Sato, 1991b). Nihonjin-gakko [Japanese full-time school] and hoshuko are the two main forms of such educational institutions. Sato (1991b) characterizes nihonjin-gakko as schools where "the students are given the education that is equivalent to the education that is stipulated by education-related law in Japan" (p. 19) and hoshuko as supplementary schools that are established in order "for OJC to maintain the academic ability in Japanese or other school subjects" (p. 19). Choices of schooling in such educational institutions for Japanese families are often very dependent on where they live, for very few locations have both hoshuko and nihonjin-gakko.

According to The History of Education for Children Overseas, the first hoshuko started in late 1950s. More and more hoshuko were built in the 1960s, mainly in North America, Europe, and Australia, whereas many nihonjin-gakko were built in Asia and Africa. This contrast was the direct reflection of the way in which the parents of OJC perceived the quality of local education. The United States, for example, was perceived as providing high-quality education, and more parents saw the need of having hoshuko where they emphasize learning Japanese as the main focus, rather than having a Japanese full-time school in their area.

In the 1970s, many more hoshuko were built as the number of students sharply increased. Also in the 1970s, nihonjin-gakko started to be built in areas such as North America and Europe as well, reflecting wishes of some parents in such areas to educate their children in nihonjin-gakko. Still, more hoshuko, compared to nihonjingakko, were built in the United States in this period. The increase in the number of OIC in the United States has constantly been more significant than in any other part 
of the world and is closely related to the sharp increase in the number of hoshuko in the U.S. Today, 40 percent of all OJC live in North America and $3 / 4$ of them go to hoshuko. Consequently, 75 percent of the students attending hoshuko worldwide are those living in the United States.

Throughout the development and increase of hoshuko, the Japanese government had financially supported it as well as nihonjin-gakko. In 1959, the government also started the program to send teachers in Japan to these schools (Sato, 1991c). Moreover, the government established an academic institute that specializes in the study of OJC, and other policies that would benefit OJC.

At the same time, the Japanese government has kept a certain distance from actually administrating these educational institutions outside Japan over the years. The reasoning behind this stance is that although those children and their families are Japanese citizens, they are staying in another country where the Japanese government cannot impose its education policy or education system. All OJC, by definition, live outside Japan and hoshuko and nihonjin-gakko are built in another country. Thus, the Japanese government does not have sovereignty. So the children's right to receive an education, and the parents' and government's responsibilities to help provide an education, as stated in the Japanese constitution, is not guaranteed. However, the government itself still recognizes its responsibility to its citizens and feels it should help the overseas school facilities and give assistance to the families who use them from the sideline.

\section{RESEARCH FOCUSING ON THE RESEARCH FIELD}

Compared to the studies on "returning children [kikokushijo]" -- Japanese children who have returned from overseas and now are living in Japan -- there is 
considerably less research being conducted among OJC while they are living overseas. There are even fewer studies of OJC that focus on communication. There is also a research gap in the area of hoshuko study. Here I will review the relevant literature on communication studies on OJC, as well as on hoshuko.

\section{Communication Studies on Overseas Japanese Children}

Kume (1991) identifies three reasons for the scarcity of communication studies, both on Japanese children living overseas and returning children. The first is that communication has not been well conceptualized in Japan. The researchers tend to focus on more tangible problems that need to be dealt with urgently. Readaptation of returning children, for example, seems more visible and urgent, and discussion of communication tends to be included as only a small aspect. The second reason is that studies on communication in Japan tend to focus on mass media studies, such as television and radio. As a result, the research on communication in Japan at the interpersonal level is very scarce. The third reason is that communication has not been discussed in Japan in relation to education. Hoshino (1989) contends that previous discussions on education included the concept of education as the means of transferring knowledge and skills but the concept did not necessarily translate into the idea of education as a process of interpersonal communication.

However, this attitude among the researchers toward the concept of communication is changing. Sakata (1989) introduced the idea that communication and education go hand in hand and thus, one cannot be discussed without the other, that education is "intentional" communication, and that education functions as the transmission of culture from one generation to the next.

Current studies of communication include Minoura (1984) and Yokogawa (1989). Minoura (1984), based on her observations and extensive interviewing, 
argues that differences in attitude toward "living 'overseas' (outside of Japan)" between children and their parents contributes to the gap in the communication style between them. Although she does not utilize the ethnography of communication in her main study, Yokogawa's (1989) ethnographic account of "learning patterns" in a U. S. school where OJC attended seems to delineate how the appropriate style of participating in the learning process, as well as what is being studied in the classroom, subtly encouraged the students "if they want to become 'good' students in the class" (p. 112). Yokogawa (1989) contends that such reinforcement affects the way Japanese children behave -- as children behave in ways that are encouraged in the classroom -- and becomes "problematic" when they return to Japan and go into the Japanese classroom where a totally different set of rules are expected to be followed.

\section{$\underline{\text { Studies on Hoshuko }}$}

While there are a number of studies focusing on various issues of Japanese full-time schools in the U. S. and other host countries where classes are held on weekdays, studies on hoshuko are almost non-existent (Center for Education of Children Overseas, 1984). Sato (1991a) contends that studying hoshuko is very difficult because "not even the actual situation of hoshuko is fully understood" (p. 449).

There are some studies that focus on hoshuko students, or on populations who have or have had regular contact in an educational setting with hoshuko students, such as local school teachers where OJC attend. In her ethnographic study, Yokogawa (1989) followed hoshuko students in a local school setting. Yanagi (1983) compared teachers at local schools in the U. S. and those at schools in Japan to find whether there were differences in the communication patterns between teacher and students, using questionnaires with the teachers in both settings. Nakanishi (1985) also used 
questionnaires, in his case addressed to hoshuko students and their parents, in order to investigate how they perceived educational differences between Japan and the U.S. Nakagawa (1989) used questionnaires with the parents of hoshuko students, focusing on how the parents prepared their children for schooling in Japan. Ohno (1983) discussed how U.S. local school teachers who have taught OJC perceived OJC in their classrooms, and how they interacted with OJC differently. He based his findings on the result of his questionnaire and his pre- and post-interviews with some of the respondents of the questionnaire.

Moreover, studies by Minoura (1984), Yano (1990) and Farkus (1983) include the analyses of school life, both of hoshuko and local schools. However, there are not many studies that directly focus on communication patterns in hoshuko as a social setting and attempts to explain them from the participants' point of view. Thus, this study attempts to shed some light on the school lives of hoshuko students from a new perspective.

\section{SUMMARY}

In this chapter, I have discussed the relevant literature on symbolic interactionism, the ethnography of communication as a theoretical framework, its application to classroom interaction research, historical and cultural information about overseas Japanese children and hoshuko, and previous studies regarding overseas Japanese children and hoshuko.

From the ethnography of communication perspective, classroom communication is considered to consist of ways of speaking, just like other social settings that are culturally patterned in a speech community. Members of a speech community who possess "communicative competence" (Saville-Troike, 1989; 
Bauman and Sherzer, 1975) know "not only the language code, but also what to say to whom, and how to say it appropriately in any given situation. Review of relevant school ethnographies which utilized the ethnography of communication revealed that the norms and values behind ways of speaking observed in classroom settings are often a reflection of a limited portion of the larger culture. Accordingly, if a student belongs to speech community which is not within the privileged section of the larger culture, that student's ways of communication may be misinterpreted.

The growth in number of overseas Japanese children (OJC) has been attributed to Japan's economic growth and change in the Japanese business world, for almost all OJC came to live "overseas" because of their parent's job. Today, there are close to 50,000 OJC. Hoshuko was originally established in order "for overseas Japanese children to maintain the academic ability in Japanese or other school subjects" (Sato, 1991b, p. 19). Hoshuko tended to be built in regions where the Japanese parents perceived the quality of local education as high-quality and beneficial to their children. Thus they wished to send their children to the local schools to be educated, but they also sent them to hoshuko, where the focus was on Japanese language and culture. The increase in the number of OJC in the United States has constantly been more significant than in any other part of the world. Today, 75 percent of the students attending hoshuko worldwide are those living in the United States.

A review of the relevant communication studies literature within an educational framework revealed that few communication studies were done in Japan, let alone communication studies that focused on OJC, because of a different view Japanese people have on the concept of communication and its relationship to education. The view is changing and more researchers in Japan see education as a process of interpersonal communication as well as an "intentional" communication 
(Sakata 1989). Many view that education functions as the transmission of culture from one generation to the next. Communication studies on OJC revealed that differences in attitude toward "living 'overseas' (outside of Japan)" between children and their parents contributes to the gap in the communication style between them, and that OJC tend to learn how to 'appropriately' behave in the classroom in local schools in their host culture. This "learned" behavior, which is appropriate in local schools, becomes "problematic" when they return to Japan and go into the Japanese classroom where a totally different set of rules is expected to be followed.

Studies on hoshuko are scarce, and very few studies focus on communication patterns in hoshuko as a social setting and try to explain them from the participants' point of view. Thus, this study attempts to shed some light on the lives of hoshuko schooling from a new perspective.

In the next chapter, I will discuss the research method used in this study. 


\section{CHAPTER III}

\section{METHODS}

This chapter presents justification for the qualitative research method, the ethnography of communication as a framework for this study, the research process, issues of validity and reliability, issues of translation and transcription, pilot studies, and data analysis.

\section{QUALITATIVE RESEARCH METHOD}

\section{Qualitative Approach}

Ting-Toomey (1984) defines qualitative research as "a mode of investigation that shares the metatheoretical assumptions of the interpretive paradigm" (p. 169). Ting-Toomey (1984) identifies three objectives of intercultural qualitative inquiry: (1) to discover the meanings and significance the social actors give to the different forms of symbolic discourse that infuse a particular cultural community; (2) to explain how social actors in that particular speech community use both interpretive principles and contextual principles "to 'make sense' of their consensually shared meanings" (TingToomey, 1984, p. 172); and (3) to understand the differences and similarities of how different actors in different speech communities, using culturally grounded interpretive and contextual principles, "arrive at an 'interpretive understanding' of one another's meanings (Ting-Toomey, 1984, p.172). These characteristics of the qualitative approach are congruent with symbolic interactionism, the theoretical perspective for this research. A qualitative approach is also congruent with my research questions in the sense that: (1) a qualitative approach allows researchers to 
value the perspective of the participants in their own terms; (2) a qualitative approach is primarily concerned with describing and understanding the phenomena in natural settings, rather than attempting to control and to predict the causal relationships of variables; and (3) a qualitative approach allows researchers to look at changing phenomena, rather than a static state of human communication. A qualitative approach to this study enabled me to study constantly changing phenomena occurring in the classroom, and to explain these phenomena by describing how they occur and are interpreted from the participants' points of view.

\section{Qualitative Case Study}

Philipsen (1982) defines the qualitative case study as:

A prose description, of an instance of a specified class of phenomena, which is written so as to permit cumulative analyses and interpretations of multiple instances of the class. (p. 4)

Philipsen (1982) claims that the qualitative case study can be "characterized in terms of in situ, non-manipulative, openly coded, participatory description" (p. 1). Those qualities of the qualitative case study allow the researcher to utilize the method for naturalistic inquiry. First, in the qualitative case study, observations take place in situ, "in the settings and at the times which are the usual contexts for the subject's actions" (Philipsen, 1982, pp. 5 - 6). The paucity of existing data in the particular context of hoshuko justified in situ observation for this study. I conducted the research on Saturdays, the usual classroom days at hoshuko.

Second, in the qualitative case study, the antecedent conditions of the phenomena are not manipulated by the researcher (Philipsen, 1982, pp. 6, 7). That is, researchers observe the phenomena in natural settings and do not control the effect of various factors, but let the phenomena emerge. The foregoing was true in my case. 
When I went into the field, I did not attempt to manipulate the environment or interactions between the participants.

Third, the qualitative case study involves the use of open coding of the data. Instead of using a priori categories, researchers look for emerging categories identifiable from the data and develop them. Use of open-coding enabled me to explore "indigenous typologies" (Patton, 1990, p. 306) and the categories that I had not anticipated, instead of imposing "analyst-constructed categories" (Patton, 1990, p. 306) and/or "ready-made theoretical categories" (Bulmer, 1979, p. 664).

Fourth, the qualitative case study is "participatory research" as the investigator "deliberately uses his or her own responses to the phenomena under investigation as one source of data" (Philipsen, 1982, p. 11). This quality of the qualitative case study allows me to use myself as an "instrument" (McCracken, 1988, p. 19) and to use the "subjective voice" as one of the sources of insight (Philipsen, p. 1982, p.11).

Such characteristics of the qualitative case study enabled me to conduct the research in a way that would best answer the research questions of this study. I utilized the ethnography of communication (Hymes, 1972) which guided me in the initial data collection and data analysis.

\section{THE ETHNOGRAPHY OF COMMUNICATION}

Ethnography of communication is a descriptive-theoretical framework originally developed by Hymes (1972). Hymes (1972) states that "ethnography of speaking [communication] is concerned with the situations and uses, the patterns and functions, of speaking as an activity in its own right" (p. 16). Bauman and Sherzer (1975) expand this definition and state that:

The fundamental premise of the ethnography of speaking ... is an 
essentially relativistic one, the understanding that speaking, like other systems of cultural behavior -- kinship, politics, economics, religion, or any other -- is patterned within each society in culture-specific, crossculturally variable ways. (p. 98)

Braithwaite (1991) posits that the goal of the ethnography of communication is "to discover, describe, and interpret patterns of speaking in particular speech communities" (pp. 145-146). The choice of this framework is appropriate for this study, since ethnography of communication "gives the researcher detailed knowledge of communication processes in context" (Poole \& McPhee, 1985, p. 127).

Identification of the speech community is one of the first steps that ethnographers must seek. A speech community is "a community sharing rules for the conduct and interpretation of speech and rules for the interpretation of at least one linguistic variety" (Hymes, 1972, p. 54), and is the focus of the ethnography of communication. Braithwaite (1991) claims that "the ethnographer must make an initial gross generalization as to the location of a speech community" (p. 157). Yet, Braithwaite (1991) also cautions that the ethnographer must "recognize that this generalization will need to be modified as more data concerning the presence of the speech community are collected" (p. 157).

It is also important for ethnographers to identify and delineate "speech situation" and "speech event" (Hymes, 1972; Saville-Troike, 1989), other social units of analysis that are essential to the ethnography of communication. Speech situation is defined as "context within which communication occurs" (Saville-Troike, 1989, p. 26), and a single speech situation "maintains a consistent general configuration of activities, the same overall ecology within which communication takes place" (Saville-Troike, 1989, p. 27). Speech events are the "activities, or aspects of activities, that are directly governed by rules or norms for the use of speech" (Hymes, 
1972, p. 56), and the basic unit for descriptive purposes utilizing the ethnography of communication (Saville-Troike, 1989, P. 27).

Hymes (1972) presented the SPEAKING mnemonic, the systematically interrelated components of a speech event, as a framework that helps ethnographers to investigate the interrelationship among the components of a particular speech event. The components represented by the SPEAKING mnemonic include: Setting and scene (actual setting and psychological scene); Participants; Ends (both goals / purposes and outcomes); Act sequence (both the form and the content of what is said); Key (tone, manner, or spirit in which an act is done); Instrumentalities (channel and code); Norms of interaction and interpretation; and Genres (categories or types of speech acts and speech events). Philipsen (1976) characterizes this framework as a device for "discovering native interpretations about speaking" (p. 15). This formula allows for episodes of interaction to be placed within a natural contextual framework, and as a result, allows ethnographers to identify the recurring communication patterns emerging from the data.

These components guide ethnographers to describe aspects of occurring communicative events that are likely to be salient. It is important to remember, however, that those components should not be used as a priori categories because research design for the ethnography of communication "must allow an openness to categories and modes of thoughts which may not have been anticipated by the investigator" (Saville-Troike, 1989, p. 4). Not all the components listed above are necessarily relevant to examining communication patterns seen in a particular speech community. It is not known until the data are gathered and analyzed which components are in fact relevant. While it is important for an ethnographer to use the SPEAKING mnemonic as a guide so that he or she can sensitively identify the communication components which may not be readily apparent, it is also important as 
an ethnographer not to impose the mnemonic as rigid categories. Once the description of the speech evens is done, the focus for ethnographers then becomes investigating the interrelationships of the components which create a speech event.

\section{RESEARCH PROCESS}

\section{Determining Research Site}

Researchers must choose a research site that will yield the data that can best answer their research questions. The research questions being asked in this study sought to discover the norms, functions, and meanings of the communication patterns in hoshuko. Therefore, finding the target hoshuko and a particular classroom in hoshuko was the first step of my research process. A Northwest regionally based hoshuko, "Japanese Saturday School" (hereafter referred to as JSS) ${ }^{3}$, was located and I was given access to it (see Appendix A). I began my fieldwork at JSS in July, 1994, and I continued it at the school until the end of June 1996.

This hoshuko was appropriate for several reasons. First, the school was within commuting distance for me, enabling me to conduct classroom observation each week. Second, I had a great "connection" (Lofland and Lofland, 1995) and knew an individual who was able to introduce me to the principal of JSS. Third, JSS was a "typical" hoshuko in terms of the number of school days and the number and kind of school subjects they taught. Fourth, JSS was also accepting children of international marriages, and conducting the study in this hoshuko allowed me to maximize the heterogeneity of the sample. Fifth, JSS had a larger enrollment than many other

\footnotetext{
3 JSS is a pseudonym for the hoshuko where I did the fieldwork. Names of people who are in this thesis are also pseudonyms. In both cases, this was done in order to protect confidentiality.
} 
hoshuko in the United States, and thus was able to provide the large pool of potential classroom sites and interviewees.

Among the classrooms in JSS, Mrs. I's first grade classroom became my core sample for this study, because of the accessibility and the strong rapport that I was able to build between the participants in the classroom -- both Mrs. I and her students -- and myself. Mrs. I was the first, and eventually the only class that I had constant access to. I was an "observer-as-participant" (LeCompte and Preissle, 1993) in Mrs. I's classroom from July of 1994 to June of 1996. The population of Mrs. I's classroom appropriately reflected the heterogeneity of the population in JSS.

Over the course of two years I was in the field, Mrs. I taught three different groups of first graders. The first group entered ISS in April 1994 (hereafter referred to as '94 First Graders), the second in 1995 ('95 First Graders), the third in 1996 ('96 First Graders). Although data were collected throughout the two years, the majority of the student data presented in this study, especially the interview data, is from the '95 First Graders. Among them, there were 23 students: 12 males and 11 females. They were either 6 or 7 years old, some were in first grade in local schools, while others were still in kindergarten. Most of the '95 First Graders entered JSS in April of 1995 and had no schooling experience in Japan, while several of them entered elementary schools in Japan in the spring, and then moved to the United States with their families. Seven of Mrs. I's students were the children of international marriages.

It is also important to note that, by focusing on a first-grade classroom in this study, I was able to explore how the students came to learn the way of being in the hoshuko in their early years in school. 
"Getting In" and "Getting Along" in the Field

The first stage of the fieldwork, once the research site is determined, is accessing and entering the field. The processes that Lofland and Lofland (1984) termed as "getting in -- gaining the acceptance of the people being studied" (p. 20) -and "getting along" -- maintaining the trusting relationship with the studied -- are crucial steps for researchers to go through in order to open the door to the field as well as "to keep the flow of information coming" (Lofland and Lofland, 1984, p. 37).

Having a successful entry to JSS and building rapport with the people in JSS was very important for me, because I was aware that JSS would be the starting point for selecting the informants for interviews as well as the primary research site for this study -- especially the participant observation portion of the study. Fortunately, I was able to have a smooth initial negotiation into the entry thanks to my "connections" (Lofland and Lofland, 1995). Dr. R., who is a Japanese language professor at a regional university and a well known and well respected member of the Japanese community, participated in my first meeting with Mr. K, the principal of JSS and one of the "formal gatekeepers" (Seidman, 1991, p. 34) for JSS. Dr. R's recommendation was a great help in quickly establishing my credibility as a researcher.

In July 1994, I visited JSS for the first time. On this first day before school hours, Mr. K took me to one of the first grade classrooms, and introduced me to Mrs. I. Then I started volunteering as a "teacher's aide" for Mrs. I. Despite the fact that they had never had volunteers in the JSS classrooms before, Mr. K, as well as Mrs. I, gave me a tremendous amount of support from the very beginning. As time went on, Mrs. I and her students seemed to become more and more comfortable with me being in the classroom, sometimes walking around, and sometimes sitting and taking notes. The other JSS teachers also became aware of my presence in the field both as a volunteer teacher's aide and a student researcher, and they became more comfortable 
with the situation. Not all the students knew that I had been volunteering in the first grade classroom when I started the fieldwork, but they also seemed to have gotten used to seeing me around and seemed to feel comfortable with my presence.

Although I started visiting Mrs. I's class with Mr. K's permission, I needed to obtain official permission from the board of education, which was comprised of representatives from local Japanese companies. Official permission was obtained from the board of education through correspondence in February, 1996. (See letter in Appendix A.)

I also realized that I still had not visited the JSS office and officially talked with Mrs. H, who was in charge of the office as well as of administration of JSS. I made an appointment with Mrs. $\mathrm{H}$ and met her at the office in April, 1996. Permission was obtained to stay in Mrs. I's classroom for the duration of the study. Also, agreement was made between myself and the newly arrived principal (who was also at the meeting) that I would make an executive summery of my research in Japanese for the school.

\section{Collecting Data}

Different field research methods are used to obtain specific kinds of data. For this study I used three data collecting techniques: a) participant observation, b) interviewing, and c) collecting cultural artifacts. In this section, I will discuss these three data collecting techniques respectively.

\section{a. Participant observation}

Participant observation is used to collect the data on various kinds of classroom interactions -- both verbal and nonverbal -- as well as contextual information, such as the description of the setting. Philips (1983) claims that 
participant observation "is best suited for studying face-to-face interaction" (p. 15) because other data gathering methods, such as mailed questionnaires and interviewing, are limiting when it comes to capturing the full context in which such interaction occurs. Participant observation allows researchers to study cultural and social behaviors occurring at the unconscious level (Sarret, 1984) that may not be identifiable through other methods.

In this study I conducted participant observation from July, 1994 to June 1996. With Mrs. I's permission, I took fieldnotes -- theoretical, methodological, and observational (Schatzman and Strauss, 1973, pp. 99-100) -- which enabled me to separate different types of information "while insuring that varying types of data are tied into the specific interactive context in which they occurred" (Corsaro, 1981, p. 129). I also kept my diary, or personal notes, along with the fieldnotes, so that I could identify my biases or emotions that could potentially get in the way of obtaining low inference description. This process turned out to be useful in delineating those biases and assumptions that I was not able to identify prior to going into the field.

I used audio tapes, when appropriate, in order to gain "accurate data" that may not be compiled by taking notes only. For both ethical and methodological reasons, I negotiated with the teachers the time and situations to use such mechanical devices so that such devices did not become too intrusive to the participants.

Although this study focused on classroom interaction, I tried to keep records of the places and events that seemed to be related to the JSS community, such as gakugeikai [student theatricals and concerts], by keeping a diary. This was because such data would allow the researcher to discover how JSS classrooms, as a "scene" (Saville-Troike, 1989, p. 138), affected children's behavior, by providing the data on communicative behaviors of the participant outside the classroom, or even, outside 
the school. These data also provided contextual information that helped the researcher understand the reality that the JSS students live in.

\section{b. Interviewing}

Interviewing is often used to collect insiders' accounts of communication patterns: how they make sense of their own communicative behaviors. Interviewing helps the researcher to understand the meaning the JSS classroom participants make of their experiences, which are often not apparent from observation or informal interviews in the field. In fieldwork that involves both observation and interviewing, gaining participants' insights on the communication phenomena helps the researcher become more sensitive to some of the communication patterns she may have overlooked during the observation phase.

In this study, I selected the following people as my interviewees.

Mrs. I: The teacher of the core sample classroom.

Mrs. I was interviewed, since she was the teacher in the classroom where I conducted my field observations. When I interviewed Mrs. I, she was in her 6th year teaching first grade at JSS. I conducted open-ended, in-depth interviews with Mrs. I, after acquiring her written consent (see Appendix B). It was a two-part interview, one of which was conducted in the middle of December, 1996, the other at the end of February, 1997. At her request, both parts of the interview were conducted at Mrs. I's house. (See Appendix D for the interview guide.)

Mrs. I's first grade students: The students in the core sample classroom.

Some of the '95 First Graders were interviewed since they were the other main participants in the classroom I observed. I employed "nonrandom sampling" (Honigmann, 1970) to try and access each family of Mrs. I's students, and request if the children and their parents wanted to participate in my study. 
In June 1996, the letters of request (see Appendix C) and self-addressed stamped envelopes were passed on to the parents through the students, who, by then, became 2 nd graders. ${ }^{4}$ Of 23 , ten families returned the answer sheet I attached to the letter of request. Of the ten families, eight agreed to let their child participate in the interview, while 2 declined to do so. Two families told me orally that they agreed to let their child participate in the interview. The informed consents for all the student participants were acquired before conducting the interviews (see Appendix B). At the students'/families' request, five interviews were conducted at their house, three in a small room at a Japanese book store, and two at a university cafeteria. (See Appendix $D$ for the interview guide.) The parents of the students were not present during the interviews.

\section{Parents of Mrs. I's students.}

Some of the parents of ' 95 First Graders were interviewed in order to obtain contextual data. I employed "nonrandom sampling" (Honigmann, 1970). The letters of request also included the clause for requesting the parents to participate in the interview as well (see Appendix C). All but one out of the ten families who agreed to let their child participate in the interviews agreed to participate themselves. Since all the parents who participated in the interview had their child participate in the interview as well, the parental consent for the student informants also served as their informed consent (see Appendix B). Of the 9 households who agreed to participate in the interviews, 8 were mothers of the children; from 1 household both parents participated in the interview together. Most of the interviews with parents were conducted at the same date and same place as their children's interviews and the informed consents were acquired before conducting the first interviews, usually the

\footnotetext{
4 I distributed the letter of request to the students, with their 2nd-grade teachers' permission, during the beginning of the class period.
} 
ones with children. However, interviews with two parents were conducted, at their request, at different dates and places from the ones with their children. (See Appendix D for the interview guide.)

\section{c. Collecting cultural artifacts}

LeCompte and Preissle (1993) claim that artifacts that people make and use often indicate "people's sensations, experiences, and knowledge and which connote opinions, values, feelings" (p. 216). In this study, some of the cultural artifacts in Mrs. I's classroom were collected as another source of contextual details. Some of the materials, such as copies of the students' homework, copies of handouts, and drawings from the students, were voluntarily given by the participants of the classroom, while other materials, such as shishin [the list of educational goals], school newsletters, and notification of school activities, were given by the participants, mainly to Mrs. I, at my request.

\section{RELIABILITY AND VALIDITY}

According to Kirk and Miller (1986), reliability refers to "the degree to which the finding is independent of accidental circumstances of the research," and validity refers to "the degree to which the finding is interpreted in a correct way"(p. 20). Although different researchers have their own ways of phrasing, it seems safe to state that reliability is mainly concerned with the replicability or repeatability of scientific findings, and that validity is mainly concerned with the "accuracy" of scientific findings, or authentic representation of the reality.

Many researchers believe that issues of reliability and validity in qualitative research need to be addressed in a somewhat different manner from those in 
quantitative research because of some of the distinctive characteristics of qualitative research design (LeCompte and Goetz, 1982; Kirk and Miller, 1986). Some of the issues addressed in experimental research are, for example, inapplicable or irrelevant to qualitative research; others need to be defined in special ways. In this section, I will discuss the issues of reliability and validity that are specifically relevant to my research.

\section{Reliability}

Reliability refers to the degree to which findings would be consistent with those of another researcher studying the same data using the same method (LeCompte and Goetz, 1982). Unlike the quantitative researchers who try to manipulate the situation to create the replicable research environment, qualitative researchers try to provide the complete description of "[research] design, data collection, and data analysis" (LeCompte and Goetz, 1982, p. 36) in order to enhance reliability.

For this study, I kept a "paper trail" 5 of how the research was designed, as well as how the data were collected and analyzed. This provides the basis for the description of "[ research] design, data collection, and data analysis" (LeCompte and Goetz, 1982, p. 36). Qualitative research rich in "primary data" -- data which provide the reader with multiple examples from the fieldnotes -- "generally are considered to be most credible" (LeCompte and Goetz, 1982, p. 42), and the use of the tape recorder, for example, provides the verbatim data that can be used as rich examples.

\footnotetext{
${ }^{5}$ Notes from "Ethnography of Communication" class taught by Dr. Poulsen in Spring, 1995. Also see Lincoln and Guba's (1985) "audit trail" (p. 283).
} 
$\underline{\text { Validity }}$

Validity concerns the accuracy of research findings. Appropriate strategies for data collection and analysis techniques by ethnographers are crucial to increase validity (LeCompte and Goetz, 1982).

One way of enhancing validity in qualitative research is methodological triangulation (Albrecht and Ropp, 1982; Sevigny, 1981; Lincoln and Guba, 1985). I combined three different data collection methods in this study in order to compensate for inherent weaknesses of each method. By strategically combining methods, inherent weaknesses in each method were "neutralized" or compensated for by the strengths in the other two complementary methods.

My initial status as an outsider of the JSS classroom was both an advantage and a disadvantage to me as a researcher. Being unfamiliar to the research site prevented me from becoming "culturally blind"6 because there was little I took for granted. It also made it easier to ask questions because, as an outsider, I was expected to know little about the particular research site for this study. On the other hand, it was a disadvantage to have little access to local understanding and interpretation of the ongoing phenomenon. Spending a considerable amount of time in the field and interacting with the participants in JSS prior to this study enabled me to have some access to the local understanding. I also tried to present myself as nonthreatening and "socially acceptable incompetent" (Lofland and Lofland, 1995, p. 56; also SavilleTroike, 1989), which helped to keep the flow of the information from participants coming and helped me as a researcher to maintain a distance from the phenomenon, both of which were important for the validity of this study.

The effect of my presence on the participants was a threat to the validity of this study because of "observer's paradox" (Saville-Troike, 1989, p. 113). "Observer's

\footnotetext{
6 Notes from "Analyzing Qualitative Data" class taught by Dr. Poulsen in Spring, 1995.
} 
paradox" refers to researchers' inevitable influence on the dynamic of interaction among the participants by just being in the field, and yet it is impossible for a researcher to conduct in situ observation and not be in the field. It is very important to address this issue in my research, specifically because of the fact that it is very unusual for JSS classes to have a volunteer -- an adult other than the teacher. ${ }^{7}$ In fact, while it is common in many primary classrooms in U.S. schools, it is uncommon in both Japanese schools and hoshuko to have a volunteer in the classroom.

In order to minimize the threat to validity that might result from the impact of my presence, I engaged in "prolonged engagement"(Lincoln and Guba, 1985) with the field prior to the main study, so that the participants in the study, both the teacher and her students, became accustomed to me and my presence thus become more "natural." I took the role of "observer-as-participant" (LeCompte and Preissle, 1993) during my fieldwork, and took part in the activities only as requested by the teacher, for too much involvement by the researcher would have changed the dynamics in the classrooms (Philips, 1983).

Validity is highly interrelated with reliability (Jorgensen, 1989), and some of the fieldwork techniques can be used to enhance both the reliability and validity of the study. In order to accomplish this goal, I attempted to : 1) keep a "paper trail" of how the research is designed, how the data are collected, and how the data are analyzed; 2) explicitly identify and thoroughly describe the whole research procedure in the final write-up; and 3) appropriately use mechanical devices such as an audiotape recorder.

Identifying expectations, biases, and prejudices is an important process for researchers to ensure the high reliability of the study (LeCompte and Goetz, 1982). It also makes the researchers aware of their own frame of reference, from which they

\footnotetext{
7 See "Study Limitation and Contributions," p. 95.
} 
make inferences. This awareness then helps prevent the researcher from coming to "spurious conclusions" (LeCompte and Goetz, 1982, p. 49), helps the researcher to acquire "disciplined subjectivity" (Ericson, 1973), and thus enhances the validity.

I expected, based on my review of existing literature on classroom ethnography of communication, that : 1) I was likely to find differences in children's communication patterns in the classroom and outside of the classroom;2) yet there were links between the children's communication patterns at home and their communication patterns in the classroom; and 3) I was likely to find differences in communication patterns and/or participants' own accounts of their communication patterns among children with different ethnic backgrounds.

I subscribe to the symbolic interactionist point of view that contends that "people collectively and actively create and negotiate meaning through their interaction"8. It is my view that human interactions, such as those among a teacher and students, are collaborative and negotiated work between the participants, and that meanings and understandings are shaped through such interactions. These assumptions are also congruent with my belief of the notion of a "social construction of reality" (Berger and Luckmann, 1966). These theoretical assumptions became my theoretical frame of reference.

I had the assumption that the everyday routine and the communication patterns in hoshuko would be different from those in U.S. schools, and also somewhat different from those in schools in Japan. This assumption was based on my personal experience of being an "international student" in a U.S. university myself as well as theoretical assumptions that hold that people in a different culture are likely to behave differently (Porter and Samovar, 1994; Barnlund, 1994; Barna, 1994). Identifying this assumption turned out to be very important since, while I

8 Notes from "Urban Communication" class taught by Dr. Poulsen in Fall, 1993. 
became more sensitive to some of the phenomena that the participants took for granted, I found myself quickly connecting the difference in communication patterns with the difference in cultural environment, when in actuality some of the differences occurred by coincidence, or because of the teacher's personal style. Being aware of my thinking process encouraged me to see if I had come to "spurious conclusions" (LeCompte and Goetz, 1982, p. 49) or if indeed it was emerging pattern, sometimes by asking the teacher or other participants about the noted communication behavior.

The process of delineating the personal expectations and theoretical assumptions is an important building block to "situate the data"9 during the data analysis. Articulating the personal and theoretical baggage the researcher brings in as she goes into the field is very important because such baggage is a big factor in shaping the whole research process. I carefully conducted this study in such a way that my personal expectations and theoretical assumptions would facilitate my research process as my personal filters, not act as blinders that might distract the research process.

\section{TRANSCRIPTION AND TRANSLATION}

\section{Transcribing the Data}

Transcription is an important source of the content and form of participants' talk. From this point of view, I audio tape-recorded communicative activities, both during participant observation and interviewing, whenever the situation allowed and the participants granted my use of an audio tape recorder. I also recorded some of "a sense of the context" (Valentine, 1995) along with each transcription. After every site

9 Notes from "Analyzing Qualitative Data" class taught by Dr. Poulsen in Spring, 1995. 
visit during the JSS school-day and after each interview, I reviewed my tapes and made "running log[s]" (Valentine, 1995) on the same day.

The immediate review of the tapes helps to improve the quality of the data because researchers can often find areas in the interviews that are ambiguous, and can check back with the informant for clarification as soon as possible. Also, researchers can make more accurate notes of observation of interviewing as a speech event (Spradley, 1979), such as how the informants reacted to the interview, or the researcher's own role in the interview, which "would help establish a context for interpreting and making sense out of interviewing" (Patton, 1990, p. 353). At the time of transcription, the names of the interviewees was coded to protect their confidentiality.

For transcriptions excerpts presented in the study, Japanese words are in italicized Roman letters with appropriate English translations in brackets. English words and phrases in parentheses indicate that they are not in original transcription but are supplemented by the researcher based on the context in order to make English translation clearer.

\section{Translating the Data.}

The issue of translation became crucial in my study because the majority of the data collected from the field is in Japanese, while the thesis is written in English. Part of the fieldnotes and interview transcription had to be available in English as well, so that my non-Japanese speaking readers would be able to examine the results of my finding.

There were two forms of translation involved in this study. One was the translation of a research instrument -- more specifically, the translation of the interview guide. This interview guide was constructed in "translatable English" 
(Brislin, 1986, p. 143) first, and then translated into Japanese. In order to minimize the risk of mistakes, I utilized "back translation" (Brislin, 1986, p. 159). A second translator, who was fluent in both Japanese and English, conducted a blind back translation into English. I then checked to see whether the original concepts and ideas "survive the decentering procedure" (Brislin, 1986, p. 160). I was able to do this process with the parents of two overseas Japanese children who helped me with the pilot interviews (see the following section).

The other translation issue was the translation of the obtained data such as fieldnotes of participant observation and interview transcriptions. Since both the participants and the researcher of this study are Japanese, most of the data were in Japanese and had to be translated into English. In such translations, researchers have to make a conscious translation decision in order to achieve "cultural equivalency" (Banks and Banks, 1991, p. 178).

\section{PILOT STUDY}

The teacher and students from one first grade class in a western U. S. elementary school took part in a pilot study for this research. The pilot study was conducted in order to provide the opportunity to clarify and improve the study procedures. It was conducted during a two month period in early 1995 in which I spent approximately 90 hours doing fieldwork in the classroom. The total class size was twenty one: eighteen were Caucasian, two Korean-American, and one JapaneseAmerican.

As the result of the pilot study, a few adjustments were made in my fieldwork techniques. For example, I developed a time log system that allowed me to keep track of the chronological order of events that happened in the classroom more 
systematically. Experiencing firsthand an elementary classroom setting made me realize that use of an audio-tape recorder is necessary in doing fieldwork in the classroom. This experience also taught me that it is important to find a primary physical location where I can take notes while observing the whole class without excessive obtrusiveness. These findings was taken into consideration when conducting the main study.

Another reason for conducting a pilot study in a U. S. classroom setting was to have a point of reference for "the other school" the children of hoshuko usually go to during the week. This was especially important for me, for I, as a Japanese student who grew up and spent most of my school life in Japan, never went to a U. S. elementary school other than as a one-time visitor prior to this pilot study. Consequently, I did not know what kinds of things go on in a first-grade U. S. classroom, and thus I did not have any point of reference to determine what was really "culturally distinctive" to JSS.

As a result of conducting a pilot study in a U. S. elementary school classroom, I was able to gain insight about the culture of a U. S. elementary school classroom, which became very valuable in conducting the analysis of this study. This added benefit from the pilot study will be addressed in chapter V.

I also conducted two pilot interviews with a couple of JSS students. One was a 3rd grade female student, the other a 1st grade female, but not a student of Mrs. I. Those two interviewees were siblings. I was able to modify some of the language in the interview to phrases that were easy for the 7-and 8-year-olds to understand by determining which words or phrases were too confusing, and replacing such words and phrases with those that were more familiar to the student informants. 


\section{DATA ANALYSIS}

Besides utilizing the framework of SPEAKING as the initial guide of the data analysis (see earlier discussion, pp. 26-27), I employed "open coding" strategy (Strauss and Corbin, 1990) for the data analysis of this study. By using this strategy, instead of imposing a priori categories on the obtained data, I sought emerging categories identifiable from the data and developed them. Such emergent categories "serve to label, separate, compile, and organize data .. |and | to summarize, synthesize and sort many observations made of the data" (Charmaz 1983, p. 111, 112; emphasis in the original). The emergent categories helped me discover "native categories" (Saville-Troike, 1989) -- categories that are created and expressed by the participant. The coding strategy also helped me search for emergent themes that inform the specific communication patterns occurring in Mrs. I's classroom.

In order to acquire "a heightened awareness of the data, a focused attention to those data, and an openness to the subtle, tacit undercurrents of social life" (Marshall and Rossman, 1995, p. 114) and do the coding effectively, I read my data repeatedly using both "vertical text reading and "horizontal text reading" (Lu, 1992) during my coding process. Vertical text reading is a way of reading text in which researchers read each text, one by one, from the beginning to the end and look for patterns within the text. Horizontal text reading requires researchers to read different texts to look for patterns across the texts. Horizontal text reading in my study also included reading texts across different kind of data, namely fieldnotes and interview transcriptions and/or interview notes. In applying horizontal text reading to the intensive reading of my data, I sometimes literally spread my written and printed data on my studio apartment floor, and looked into a certain category or event across the different 
fieldnotes. This method of cross-referencing was done to identify gaps and overlaps in the data and to help enhance the validity of the research.

Three key events were identified by using the aforementioned strategy for a in-depth analysis. In interpreting the data, I attempted to connect the micro-level findings of the classroom setting to the macro-level societal context of school and community. 


\section{CHAPTER IV}

\section{ANALYSIS OF DATA}

This chapter presents an analysis of the prominent communication patterns that I observed in Mrs. I's classroom, which is the core classroom in the hoshuko. General descriptions of the hoshuko as a whole are presented. Also included are the analyses of speech community, speech situations, and three selected speech events that were found to be salient during the fieldwork for this study.

\section{DESCRIPTION OF THE RESEARCH FIELD}

This section presents the general context of the JSS hoshuko in which teachers, like Mrs. I, and students communicate with each other, as well as among themselves in Japanese.

The Research Field: Japanese Saturday School as The Primary Research Site.

"Japanese Saturday School" (JSS) ${ }^{10}$ is hoshuko, the supplementary school for Japanese children living in a metropolitan area in the Northwest region of the United States. JSS is held in a local middle school building regularly on Saturdays, and some Fridays during June, July, and August. Japanese speaking natives teach school subjects in Japanese, using the same textbooks used in schools in Japan. JSS has its elementary school division ( 1 st - 6th), middle school division (the students are called "1st" - "3rd" graders in middle school, not 7th - 9th graders) and high school division

\footnotetext{
${ }^{10}$ As mentioned in the previous chapter, "Japanese Saturday School" (JSS) is a pseudonym for the hoshuko where I did the fieldwork. Names of people who are in this thesis are also pseudonyms. In both cases, this was done in order to protect confidentiality.
} 
(again, the students are called "1st" - "3rd" graders in high school instead of 10th -12 th graders). The students study in individually-assigned classrooms from 9:00 to $3: 30$.

The school year for JSS starts in April and ends the following March. There is a two-week-long summer break in early August and a two-week-long winter break in late December. JSS has an "entrance ceremony" and an "opening ceremony" on the first day of each school year, and a "closing ceremony" and a "graduation ceremony" on the last day of each school year. There are usually no breaks between March and April, so often times the day of the "closing ceremony" of the previous school year and the day of the "opening ceremony" of the new school year is only one week apart. JSS also observes those holidays observed by the local metropolitan schools. Several JSS days are added on Fridays during June, July, and August to replace Saturdays that are lost during the break and the holidays in order to guarantee 50 school days.

The building that JSS currently borrows from the local school for its students is one-story and takes up a whole block by itself. It is located in a quiet residential area with a clump of trees on one side. The building has a lawn-covered playground and a recently-built athletic track, both adjacent to the building.

Inside the building, 14 specific rooms are each assigned to a specific class. Mrs. I's first grade classroom, for example, is in the back of the building near the other first grade classroom and two second-grade classrooms. JSS teachers and students are not supposed to use the other rooms unless otherwise noted. The local school's cafeteria area and gym area are also borrowed. The cafeteria space is used for the entire JSS student body (and some teachers) to eat lunch. The gym is used for the students to play in during recess and after school with adult supervision, and for the entire JSS to have shukai [a big meeting which all students and teachers attend; 
usually held at 3:00] on some of the JSS days. There is a local school's faculty room space near the cafeteria, which JSS also uses for their faculty room. The principal usually uses this room to do his work, and other teachers use the space during the break, and some during lunch. The teachers' meetings are held here. There is also a storage room where JSS keeps its own copy machine. This room seems to be occupied only by JSS property and is not shared by the local school. The storage/copy room also keeps several shelves of books. Around 3:00,3-4 parents of the JSS students, who are on duty to be in charge of library books, roll 2 bookshelves on wheels out in the hallway. A small section of the hallway and the storage room, then, becomes JSS's instant, portable library.

As of October 1996, there were a total of 266 students attending JSS: 209 in the elementary school division, 44 in the middle school division, and 13 in the high school division (Japanese Overseas Educational Servises, 1997). The number of students in JSS seems to have increased in the recent past. Just this year, spring of 1997 , the 3rd grade class, which used to be a single class, was split in two because the number of students in the classroom exceeded 35 and the classroom became too crowded. Currently, there are 15 JSS teachers, including the principal. There is no vice principal, counselor, music, PE, or art teacher. There are no professional librarians for JSS. The portable library that appears every JSS Saturday around 3:00 is managed by the parents of JSS students who take turns helping the students check out and return books to the library.

\section{ANALYSIS OF JSS HOSHUKO}

I employ Hymes' descriptive-theoretical framework (1972) in the study of communication patterns in this particular educational setting. Hymes' framework 
allows researchers to "discover, describe and interpret patterns of speaking in particular speech communities" (Braithwaite, 1991, pp. 145-146). Hymes' SPEAKING mnemonic guides researchers to describe aspects of occurring communicative events that are likely to be salient. And by investigating the interrelationship among the salient aspects of communicative events, researchers are able to discover "native interpretations about speaking" (Philipsen, 1976, p. 15).

\section{Speech Community}

Speech community is "a community sharing rules for the conduct and interpretation of speech and rules for the interpretation of at least one linguistic variety" (Hymes, 1972, p. 54). Identifying a speech community is important in this framework because as Braithwaite (1991) contends, "[t]o begin to analyze specific acts of speech, those speech acts must first be located within a speech community" (p. 157). While shared language use is recognized as a major factor in defining a speech community, it is important to see it as "an integral social unit" (Hymes, 1972, p. 55). Braithwaite (1991) suggests that researchers discover and describe "the degree to which (1) a group of speakers share aspects of linguistic variation ..., (2) a group of speakers share communication rules of speaking ..., and (3) shared meaning is present among a group of speakers" (p. 146, emphasis in original).

As noted earlier, this is a classroom ethnography. The core classroom under study is composed of Mrs. I and 23 students ages 6-7. They seem to be the only people who are expected to be in the classroom constantly, and it is very rare that other people come in and out while they are studying in the classroom. This is unlike several U.S. classrooms that I previously observed, where there were often volunteers present in the classroom, and some of the volunteers went in and out of the classroom, depending on the kind of help they were doing in the classroom. In JSS 
classrooms, when people do come in, they often are marked as "visitors" and announced as such to the class by the classroom teacher either beforehand or on the spot. Even the teachers and students of other classes or the principal of JSS become "outsiders" of Mrs. I's classroom, especially when the children are studying. Such outsiders often say "sumimasen, chotto ... [Excuse me, but ...]" when they come in, and classroom activities are often times interrupted and put on hold while they and Mrs. I are talking. The conversations are usually very brief, and they often say "shiturei shimashita" or "gomennasai," both of which express apology for the interruption. This kind of interruption, too, is very rare. In my experiences in several U. S. classrooms, the classroom volunteers went out mainly because the teacher asked them to do certain tasks that required them to leave, such as bringing back something from the office. In such cases, there were almost always no apologies from the returning volunteers. They simply came back into the classroom silently.

Membership of parents in the speech community of Mrs. I's classroom seems to be secondary, or remote. The parents are not usually present in the classroom, except for the day set aside specifically for "sankanbi" [day when parents or guardians come to their child's classroom and observe the class activity]. Many parents come to school at the end of the day to pick up their children, and some may even have a peek in the classroom through the small window on the door, but over the course of 2 years of continuous fieldwork, I did not witness the parents coming into the classroom before students were dismissed for the day, especially without an oral invitation from Mrs. I. Thus, once the JSS day begins at 9:00, parents seldom come into the classroom, especially without previous notice to the teacher.

The custodians/janitors are not primary members of the speech community of the classroom either, although they are physically present in the same school building. The custodians do not usually come into the classroom during the JSS classes. 
During my observation, I saw the custodians come in only when Mrs. I requested them to, and classroom activities were put on hold while they were there. They do come into the classroom to clean up, but only after the JSS day is over and the students are gone. Also, the custodians do not share the knowledge of the Japanese language, and only Mrs. I speaks in English to them while they are in the classroom. I have seen some older students chatting with the custodians in English, but, again, only after school is over for the day.

Interviews and observation revealed that Mrs. I and her students, the primary members of this speech community, also belong to other speech communities, and orient themselves to this specific speech community in very specific times and situations. The families that I talked to seemed to have a variety of ways of communicating to each other and to non-family members in English and/or Japanese. Yet on the school day, from 9:00 to 3:30 until the teacher says good-bye, the teacher and students seem to respect the rule as to which language to use. Several times I witnessed the kids shifting their choice of language (Saville-Troike, 1989) soon after school. For example, when I was given a ride by one of the mothers of Mrs. I's female students, the student started speaking to her mother, who is a Japanese native, requesting in English that they go to McDonald's because she was hungry. This student was one of the children from the international marriages. Previous observations I made revealed that she almost always talked to her father who is a native English speaker in English, and many times she talked to her Japanese mother in English as well. In another case, I witnessed a girl whose parents are both Japanese speaking natives, and another girl whose mother is a Japanese speaking native but whose father does not speak Japanese, playing together and communicating with each other in English outside the school building while they were waiting their ride to come. It is important to note that this was not necessarily "typical" choice of many 
of the other children in Mrs. I's classroom from similar family backgrounds. For example, one of Mrs. I's student told me that he and his good friend, both of whom are the children of international marriages and attend to JSS, "uses Japanese most of the time" while they are playing together at each other's home (ITW - Ch $3, \mathrm{Ch} 4$ ).

\section{Speech Situation / Structure of JSS Day}

A JSS day starts at 9:00 and ends at 3:30. There are 5 class periods, fifty minute each, two 10-minute recesses, a 20-minute recess, and a 60-minute lunch time/recess in between. The beginning and end of each class period are marked by kiritsu-rei [kiritsu means stand up; rei means bow], the ritualistic sequence of standing up, standing straight and bowing. There are two classroom meetings, one before the 1st period and the other after the 5th and last period, both without the marker of kiritsu-rei during these transitions. There are three class periods before the lunch time/recess and two following. Figure 1 shows the daily schedule.

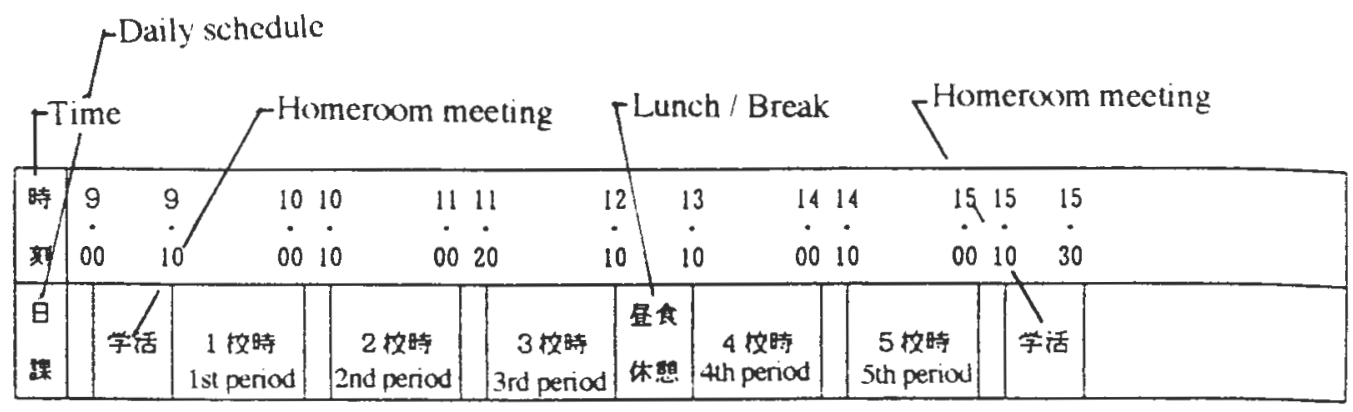

SOURSE: Japan Overseas Educational Servises, Kaigaishijo Kyoiku [Education for Japanese overseas children], 1995

\section{Figure 1. Daily schedule at JSS}

The timeline is rather fixed in terms of when the class should begin and when the class should end. For example, during my observations of Mrs. I's classroom, there was no timetable visible to the students. And yet the students, especially those who 
were already able to tell time by looking at the clock, seemed to know the "timetable" and prepare for the beginning, or the end, of the class. These students sometime expressed that knowledge by saying it is time to get back to the table and get ready, for example, when it was close to the end of recess (Ob-2-4). Or, Mrs. I would look at the time and say, "Oh, it's time already, are you preparing?" on similar occasions (Ob-1-20). Whenever a special event came up and the day's timetable was changed, Mrs. I would make the announcement regarding the circumstances of the time change and the adjusted timetable. Mrs. I almost always wrote the changed timetable on the blackboard as she was making the announcement.

While "a JSS day" gives a larger context -- "speech situation" -- in which Mrs. I and her students communicate with each other, class periods and other segments of time, like classroom meetings and breaks, seem to provide an even more specific context -- smaller "speech situations." It is not appropriate to identify these segments as "speech events" because there may be several change in activities within these segments of time and thus the same rules do not necessarily govern these segments throughout (Hymes, 1972). Instead, calling these episodes or segments "speech situations" seems more appropriate. Below are the descriptions of all the smaller "speech situations." Many of these speech situations were labeled using natives' terms, the words and phrases that the participants provided through observations and interviews. In the description, the word 'preparation' is a researcher-imposed term, since this segment of time was never labeled by either Mrs. I or her students (see Figure 2).

Preparation: Before 9:00, JSS teachers usually bring teaching materials, the ones that they had to take home after the last JSS day, back to the classroom. Also, JSS teachers often go to the storage/copy room to make copies of drills or self-made 


\begin{tabular}{|c|c|}
\hline s]" & *T -.- Teacher \\
\hline preparation & $\begin{array}{l}\text { (*T's preparation in the classroom }(8: 00-8: 45)) \\
(* * \text { 's preparation }(9: 00 \text { ish - until T comes })) \\
\text {-"leaving messages..." }\end{array}$ \\
\hline $\begin{array}{l}\text { "morning meeting" } \\
(9: 00-9: 20)\end{array}$ & $\begin{array}{l}\text {-"T comes into the classroom" } \\
\text {-selection of otoh-ban } \\
\text {-"(proper) greeting"("kiritsu-rei_[stand-up-and-bow]") } \\
\text {-roll call } \\
\text {-"(Students)speak about their week" } \\
\text {-"announcement" } \\
\text {-"sing a favorite song" } \\
\text {-"what (kind of) day is today" } \\
\text {-"finish up" }\end{array}$ \\
\hline $\begin{array}{l}\text { "1st period" } \\
\text { (usually "Japanese time") } \\
(9: 20-10: 00)\end{array}$ & $\begin{array}{l}\text {-"practice } \frac{K a n j i "}{\text { "dictation (of Kanji)" }} \\
\text {-"reading textbook aloud" } \\
\text {-" kiritsu-rei_[stand-up-and-bow]" }\end{array}$ \\
\hline "10-minute break" & unattended by teacher; no outside or gym \\
\hline $\begin{array}{l}\text { "2nd period" } \\
\text { (usually "mathematics } \\
\text { time") }(10: 10-11: 00)\end{array}$ & $\begin{array}{l}\text {-"kiritsu-rei_[stand-up-and-bow]" } \\
\text { (study "according to the textbook," "according to the } \\
\text { unit") --- group work } \\
\text {-"kiritsu-rei_[stand-up-and-bow]" }\end{array}$ \\
\hline "20-minute break" & $\begin{array}{l}\text { unattended by teacher; outside play } \\
\text { may read books in the classroom }\end{array}$ \\
\hline $\begin{array}{l}\text { "3rd period" } \\
\text { (usually "Japanese time") } \\
(11: 20-12: 10)\end{array}$ & $\begin{array}{l}\text {-"kiritsu-rei_[stand-up-and-bow]" } \\
\text { ("study the textbook") } \\
\text {-"kiritsu-rei [stand-up-and-bow]" }\end{array}$ \\
\hline$\frac{\text { "Noon break" "Ianchi]" }}{(12: 10-1: 10)}$ & $\begin{array}{l}\text {-wash hands; go to the cafeteria; eat } \\
\text { (noon break) }\end{array}$ \\
\hline "4th period" & -"kiritsu-rei [stand-up-and-bow]" \\
\hline $\begin{array}{l}\text { (usually "mathematics time " } \\
(1: 10-2: 00)\end{array}$ & $\begin{array}{l}\text { ("uses way of teaching according to individual's } \\
\text { (speed)") } \\
\text {-"kiritsu-rei_[stand-up-and-bow]" }\end{array}$ \\
\hline "10-minute break" & unattended by teacher; no outside or gym \\
\hline $\begin{array}{l}\text { "5th period" } \\
\text { (usually "Japanese time" } \\
\quad(2: 10-3: 00)\end{array}$ & $\begin{array}{l}\text {-"kiritsu-rei_[stand-up-and-bow]" } \\
\text {-use of language/(mainly) Japanese grammar } \\
\text {-"dictation (of Kanji)" } \\
\text {-"do the drill (to review)" }\end{array}$ \\
\hline $\begin{array}{l}\frac{\text { "classroom time" or }}{\text { "before-going-home }} \\
\frac{\text { meeting" }}{(3: 00-3: 30)}\end{array}$ & $\begin{array}{l}\text {-"write 'nakayoshi" " } \\
\text {-" read book" or } \\
\text {-" } \frac{\text { read kamishibai [paper picture shows]" }}{\text {-hand out new homework }} \\
\text {-hand out previous homework (corrected) } \\
\text {-"(parting) greeting" } \\
\text { (includes "kiritsu-rei_[stand-up-and-bow]") }\end{array}$ \\
\hline
\end{tabular}

Figure 2. Speech Event Matrix 
handouts, either for use during "Japanese period" and "mathematics period" or for homework.

JSS students usually arrive at school a little before or at 9:00 by school bus or their parents' car. When Mrs. I's students come in to the classroom, they usually take off their backpacks, take their homework out of the backpacks and put it in a small white basket placed on a chair at the back of the room near the door. They take out their textbook, notebook and workbook, and pencil and put it at their table, and take out their lunch box and put it by the space near the sink, also located near the door. This set of behaviors appeared to be a "routine" (Saville-Troike, 1989, p. 42). In one incident, when a student came up to me on his arrival to the classroom and asked me what he should be doing or where he should be putting his homework, I took a long pause to decide if I wanted to answer him or not. I did not want to direct and create his activities. Then, another student who was also in the classroom told the first student, "Oh, it (the homework) goes there," and showed him what to do.

"Leaving messages (on the blackboard)" occurs in this segment. In this activity, Mrs. I leaves messages on the blackboard before she leaves for the teachers' meeting. Types of messages Mrs. I leaves include: instruction/assignment ("Today, please read (the) book quietly"), encouragement ("Try hard today"), greeting ("Good morning, everybody," "How are you today?"), or reminder ("don't forget OO [such and such]"). Students who arrive at the classroom while Mrs. I is still in the faculty room for the teachers' meeting, would read the message, and/or do tasks as instructed.

"Morning meeting": One of the class meetings happens in the morning before the 1st period. A 10-minute segment, from 9:00 to 9:10, is reserved for the all the grades to use for this class meeting. Although the schedule above suggests that there are 10 minutes for this meeting, Mrs. I stated that she "usually takes about 20 minutes" (ITW -T1). Mrs. I believes that the morning meeting provides an 
opportunity for the children to "communicate with each other" and to recall what they did last time and what comes next. (ITW - T1). Mrs. I also acknowledged in the interview that some of the activities during the morning meeting provide an opportunity for the children to "practice to speak in ... polite language" (ITW - T1), an opportunity that JSS students, including Mrs. I's first graders, seldom have outside the classroom setting.

Some possible activities in the morning meeting in Mrs. I's classroom include: "The teacher comes into the classroom;" selection of otoh-ban; "(proper) greeting;" roll call; "(Students) speak about their week;" "announcement;" singing a favorite song; "what (kind of) day is today" [an activity in which students pick a phrase to represent a goal for the day by majority vote]; and "finish[ing] up." Not all the activities are done in every morning meeting. Time of year is one factor that determines how the morning meeting is carried out. Mrs. I usually leads the morning meeting until around September, which is close to about half-way through the JSS school year. She believes it is too hard to for students to lead the morning meeting in the beginning of the year because her students are first graders and thus "are not used to (the) school (JSS) yet," because it takes a lot of time when she lets the children do the morning meeting, and because the children "do not quite understand" (ITW - Tl). Around September, Mrs. I starts letting the students lead the meeting. Also a limited time frame is another factor in determining which activities to include and which not to. For example, I sometimes heard Mrs. I saying "Oh, we have plenty of time today. Let's have someone tell us about their week."

"Japanese time": Mrs. I and her students usually study Japanese in Ist, 3rd and 5 th period, but Mrs. I sometimes decides to teach Japanese in two class periods in a row if she feels it is appropriate in the situation and beneficial for the students. For example, if a previous Japanese class ends in the middle of a project, Mrs. I often has 
the students resume the project in the next hour. These periods when they study Japanese are usually referred to as "Japanese time."

The possible activities that occur in the "Japanese time" are: "reading textbook (aloud);" "practice Kanji;" "dictation (of Kanji /sentences with Kanji);" "study the textbook" (or "study the unit in the text"); "use of language/ (mainly) Japanese grammar; "what is necessary in the textbook that day;" and "do the drill (to review)." Each student has their own textbook for "Japanese time" that he or she brings from home every JSS day, and activities described above are almost always very closely related to the content of the textbook.

"Mathematics time": Just like "Japanese time," activities that go on in this segment are also closely related to "the unit" in the textbook that the students are studying at the time, as well as the math concepts to be learned in that particular unit. When the class complete studying a particular unit, Mrs. I usually lets the students know that it is time to move on to the new unit by saying, "Well, then, please open p. OO [page number of the next unit]." or "Okay, let us move on to the next (unit)."

Mrs. I categorized and contrasted the two ways of spending "mathematics time." One is the way in which all the students learn "all together" and study "according to the textbook/unit" (ITW-T1), which almost always is the way Mrs. I uses it in the first part of learning a unit. The other is the way in which students learn "according to the individual's (speed)" (ITW-T1). During the interview, Mrs. I acknowledged that there exists a gap between 'finish-early children' [students who learn very quickly and finish solving math problems quickly] and 'finish-late children' [students who are slow in understanding and thus take a long time to finish solving their problems], and gave the rationale for the two different approaches.

"Lanchi [lunch]" / "Noon break": This one-hour segment is divided into two sections: lunch time and recess. During lunch time, JSS students and some JSS 
teachers go to the cafeteria and eat the lunch they bring from home. Many JSS teachers in the elementary school division, including Mrs. I, usually sit with their students and eat lunch. Other teachers have the option of eating lunch in the faculty room, and most JSS teachers in the middle school and high school divisions do this while their students sit together at their assigned table. For Mrs. I's class, activities in this situation may include: washing their hands, forming a line, walking to the cafeteria in line, and eating. When Mrs. I's students finish eating, they individually let either Mrs. I, or me, know that he or she has finished eating, and leave. The rest of the hour is spent as recess. So, the sooner a student finishes eating, the more time he or she ends up having for play. (See Breaks for the description of the recess portion of this segment.)

Kaeri-no-kai [Before-going-home meeting]: The second of the two class meetings happens right after the 5th period in which a 30-minute segment (from 3:00 to 3:30) is reserved for all classes. In Mrs. I's classroom, the possible activities in this segment include: "write 'nakayoshi" [writing what the students studied at JSS that day, what they did besides studying, homework for the next week, and things to bring to the next JSS day on a piece of paper ${ }^{11}$ ]; "read book" or "read kamishibai [paper picture shows];" hand out homework to be done by next week; and hand out previous homework that is checked and corrected. Mrs. I and her students end this segment by doing "the (parting) greeting." 12

Breaks: There is a 10-minute break between 1 st and 2 nd period, a 20-minute break between 2 nd and 3 rd period, a noon break following lunch and before 4th

\footnotetext{
11 "nakavoshi" is the name of a form that Mrs. I created for this activity so that the students can write down each item in designated spaces on the paper.

${ }^{12}$ In Japan, saying good-bye, or other kinds of words people exchange for leave-taking, are considered a type of greeting.
} 
period, and another 10-minute break between 4th and 5th period. These breaks are marked by the absence of classroom speech events.

Ten-minute breaks can be categorized as "short breaks." During short breaks, no playing outside or in the gym is allowed. The students may play in the classroom, drawing pictures or playing games. The 20 -minute breaks and the noon break can be categorized as long breaks. Noon break, a break following lunch time, can be considered a long break, since within the hour of lunch/recess time the students usually spend only half an hour eating lunch and use the rest of the time for playing. During these long breaks, the students may go outside or to the gym and play, or they may read, draw pictures, and play games in the classroom like during short breaks. The students who go outside the classroom to play have to return by the time the class resumes. For both of the long breaks, the school arranged to have the custodians ring the bell 5 minutes before the break ended, and many students seemed to know that the bell was a good indicator that it was time to head back to the classroom. Even those students in the classroom sometime mentioned, after the bell rang, "Oh, the bells," and headed to their table and sat down, or had a last drink of water.

With both kinds of breaks, JSS students do not have to be attended; there is no "duty" for the JSS teachers. This resembles "break time" in school in Japan, where there are no "duty" assigned to the teacher, and where students may play on school property without close adult supervision. However, this is quite different from "recess" in U. S. elementary schools, where several teachers "on duty" supervise the children throughout. ${ }^{13}$

${ }_{13}$ "Duty" is the term that many U. S. teachers use to describe their responsibility to watch over students during recess. 
Structure of JSS Day: The Students' View

During the interview, students" description of "a usual JSS day" and "what they learn at school" showed how they conceptualize the structure of a typical school day and categorize the elements of the structure. While many of the cultural concepts were shared by Mrs. I, they seemed to have their own particular ways of organizing those categories.

While two of the student informants listed the events chronologically like Mrs. I (ITW - Ch 6; Ch 10), many students identified four major categories for the "time segment" in a random order : "kokugo (no jikan) [Japanese (time)]," "sansu (no jikan) [mathematics (time)]," "kvukei-jikan [break time]," and "lanchi [lunch]." Some of these categories were further broken down into some of the typical activities that happen during those segments, such as practicing Kanji and reading for Japanese time, and calculation or drill for mathematics time.

Another way the students subcategorized what they learned during Japanese time or mathematics time by using the heading of the "unit" in the textbook. For Japanese time, it is often a title of the story which is the main focus of the study in a particular unit. For mathematics time, it is often the name of the major math concept to be learned in a particular unit, such as addition and subtraction. One student described that they learn "what is in the Japanese textbook" during Japanese time, while they learn "what is in the mathematics textbook" during mathematics time" (ITW - Ch 3).

Break time seemed an equally important, if not more so, time segment for the students. "Kyukei-jikan [break time]," as well as activities during these breaks were almost always mentioned by the student informants, along with what is considered class time, such as Japanese time and mathematics time, and activities that occur 
during such time segment. One student started talking about what she does with friends, with little mention about what they do during the class time.

Child: (I/We) play with friends ... (I/We) talk with friend...

Interviewer: What kind of things (do you) talk about (with friends)?

Child: Like where we went for a trip .... or like there are many, many math calculations we have to do ....

She continued to tell me about what she would do during recess or after school. It was only after I asked, "What about class time?" when she started talking about what the students do during class time.

Homework seems to be a part of all school activities in the minds of many student informants. Many included the description of homework in their response when the researcher asked them to describe "a usual school day," even though it was something that they have to do during the week, not on the JSS day (ITW- Ch 2, Ch 7, $\mathrm{Ch} \mathrm{10).} \mathrm{Kanji} \mathrm{is} \mathrm{one} \mathrm{of} \mathrm{the} \mathrm{most} \mathrm{frequently} \mathrm{mentioned} \mathrm{homework} \mathrm{assignments} \mathrm{by}$ the students.

Most of the student informants described the key/tone of class time as "omoshiroi [interesting]" (ITW - Ch 9; Ch 7) or "tanoshii [fun]" (ITW - Ch 4 ; Ch 9; Ch 10). Although the sense of fun does not necessarily seem to come easily to them all the time, and even though some confessed that they sometimes "wish that (class time is) shorter" so that they can go out and play (ITW - Ch 1), they were quick to restate that it was fun and interesting. Based on my observation, the students' attitude in taking part in the classroom activities seem to support their statements.

One student articulated that difference in tone between class time and break time. He stated, "benkyo no toki shizuka [(it is) quiet during studying (class) time]" (Ch 10) and went on to say that it is more noisier during break time even when they are playing in the classroom. 


\section{ANALYSIS OF SELECTED SPEECH EVENTS}

Examination of observation notes and interview notes revealed that there were discrete speech events within smaller speech situations described in the previous section. For the purpose of this thesis, I selected three speech events for close analysis: kiritsu-rei [stand-up-and-bow], "(Students) speak about their week," and practice Kanji. These speech events were selected because I felt they would best reflect the complexity of speech events/class activities held in this particular educational setting, and because these events would be good examples to compare with some of the speech events occurring either in traditional U. S. classrooms, or traditional Japanese classrooms.

\section{I. kiritsu-rei [stand-up-and-bow]}

Kiritsu-rei is the ritualistic sequence of standing up, standing straight, followed by bowing. In Mrs. I's classroom this event is repeated at the beginning and end of each class period. Morning greeting during the morning meeting and parting greeting during before-going-home meeting also include kiritsu-rei.

Kiritsu-rei, the activity itself, is always initiated by two designated children referred to as otoh-ban, who walk up quietly and quickly to the front of the classroom. They stand on either side of Mrs. I, who is always in front of the class whenever this activity occurs. The otoh-ban then say in loud and clear voices, "Kiritsu [stand up], kiotsuke [stand straight], rei [bow]." While the otoh-ban should be modeling the act sequence as they say it, Mrs. I and the rest of the students are also supposed to follow these otoh-ban's directions to stand and bow. Model kiotuke would be standing straight with their hands at their sides, and model rei would be bowing about $80^{\circ}$ while keeping their hands at their sides. 
There are generally two types of act sequences that accompany the action of standing up and bowing. One type is the announcement of the time segment. After everybody in the classroom finishes bowing one time, otoh-ban say:

Kokugo (or Sansu) no jikan desu. [(This) is Japanese (or mathematics) time.] or,

Oyasumi-jikan desu. [(This) is break time.]

After the announcement, the otoh-ban go back to their seats and sit down if it is the beginning of the class, and if it is the end of the class, both the otoh-ban and the rest of the students are dismissed. The other act sequence occurs during morning greeting and parting greeting, that is, as soon as the otoh-ban say "rei [bow]," and they, the other students, and Mrs. I start bowing, they also start saying the ritualized phrase for morning (or parting). For example, for the morning greeting, the students and teacher then start saying together:

sensei, ohayoh gozaimasu. [Teacher, good morning.]

minasan, ohayoh gozaimasu. [Everybody, good morning.]

Everybody is expected to say those words loudly and clearly. And when saying the "ohayoh gozaimasu [good morning]" part of the greeting, the teacher and the students bow to about $80^{\circ}$ with their hands at their sides. The students and Mrs. I turn their body several times to the different directions and bow several times. Upon completion, the students sit down and the otoh-ban return to their seats and sit down. The whole sequence of acts is carried out very quietly and usually there is only the sound many students make when they put their hands to their sides (a muffled clapping-like sound), and the sound of chairs being dragged against the floor when the students pull back their chair as they sit down. When kiritsu-rei is part of the parting greeting at the end of the school day, it serves as a signal for the students that school is over. 
While Mrs. I and her students remain the participants of the event, the role of the otoh-ban, who are usually selected right before the morning greeting, seems to change the dynamic relationship among the participants in this particular speech event. The otoh-ban would "greet properly and lead (the meeting)" (ITW - T1) as part of their job for the day, and the rest of the students and Mrs. I follow the otohban's signal of "kiritsu [to stand up]," "kiotsuke [to stand straight]," and "rei [to bow]." One of the very few times that Mrs. I steps in and says something is when some of the students do not follow the otoh-ban's signal and neither otoh-ban seem to notice nor stop the process and have the class redo it "correctly." Another time is when Mrs. I feels that some of the students are being sloppy in performing the greeting. Shaking their head around and/or giving a shallow bow, for example, is considered "sloppy." In both instances, Mrs. I would stop the whole process of kiritsu-rei and ask the otoh-ban to repeat it from the beginning.

The tone of the ritual performance seemed to be happy, lively but serious. A joking tone is not allowed in this event. The form of speech in this event is very formal, both in terms of verbal and non-verbal components; the phrase for both the announcement and the greeting is to be done in a complete and polite form ${ }^{14}$. Bowing is also done in complete form. The participants' body needs to be straight when they stand up, and making a deep bow is very important, while a light nod or twisting the body while doing the bow is considered sloppy and subject to redoing. Several bows in different directions, which happens during the two greetings, is not necessarily congruent with a complete degree of formality, but the students and Mrs. I seem to be doing so, rather, to show that they are greeting everybody else in the classroom. The norm of interaction seems to be to do the greeting correctly to its

\footnotetext{
it In this thesis, the terms "poitte form" and "polite language" is not used as the same meaning as honorifics. (for more detailed explanations, see p. 83.)
} 
detail and formality, while the norm of interpretation seems to be that the greeting is a very important event, and it is important for the students to do it right.

This activity can be identified in the genre form "ritual." Ritual is defined as "a form used to affirm a sense of shared identity by providing a culturally prescribed ordering of behavior that members can follow" (Braithwaite, 1991, p. 159). Fixed routine of the act sequence, prescribed forms of the speech, and tone of activity, all suggest the ritualistic nature of this communicative event. Even the physical setting in which the act occurs, in terms of where all the participants should be, indicates that there are definite, "culturally prescribed ordering behavior" which members are supposed to be following.

For Mrs. I, kiritsu-rei serves a number of purposes. Besides getting the attention of the students, it is to "have kejime [a clear distinction]" (ITW-T1), the distinction between the breaks and the classes. Kiritsu-rei becomes a marker that separates playing time from class time. During the interview when I asked Mrs. I to comment about kiritsu-rei, she mentioned kiritsu-rei is also closely related to the sense of "(Japanese) manner." Mrs. I described kiritsu-rei as one of the Japanese customs that she as a teacher has "an opportunity" to teach to those "who are not in Japan," and is one of the activities that the old can pass on to the young (ITW-T1). Compared to her experience in a Japanese (as a foreign language) class at a U.S. local school where she teaches and where the same kiritsu-rei activity is enacted in the classroom, Mrs. I says that she makes an effort to have the students in hoshuko class follow the correct form, both verbal and non-verbal, more vigorously than she would in her U.S. classroom.

Philipsen (1987) defines ritual as "a communication form in which there is a structured sequence of symbolic acts, the correct performance of which constitutes homage to a sacred object" (p. 250). For Mrs. I, the particular sacred object seemed 
to be the particular relationship between teachers and students. Mrs. 1 indicated that, while she did not want to be in a one-up position to the students, she also hoped that there is respect from the students to her as somebody who is teaching them. Also, by repeating this ritual, members of this classroom, both Mrs. I and the students, seem to be honoring their identity as "competent persons in Japanese ways of communicating."

To the students, their sacred object also seems to be the role of the otoh-ban. Otoh-ban are selected each morning, by Mrs. I, in the order of the name list in the roll book. Besides leading kiritsu-rei, they are first persons in line to the cafeteria, the persons who are usually called and asked by the teacher to pass out worksheet or other materials, or do other things that are requested by Mrs. I (ITW - Ch 8). Each student takes a turn experiencing this role at least once in the school year, and the responsibilities and "tasks" that the role entails. Observation and interviews indicated that every student is able, or at least should be able to know exactly how they should be leading the kiritsu-rei. When I asked the students about the otoh-ban and asked who they are and what they do, they were able to correctly describe the act sequences and variations of the kiritsu-rei activity (ITW - Ch 10; Ch 2). Kiritsu-rei was often times one of the first tasks that students mentioned that the otoh-ban have to do (ITW

- $\mathrm{Ch} 2 ; \mathrm{Ch} 8$ ). Based on observation of this activity, and responses during the interview when I asked about the kiritsu-rei and other responsibilities that the otohban bear, the students seemed to be proud and appeared to enjoy the role they take, including carrying out kiritsu-rei.

\section{II. "(Students) speak about their week"}

About three children "speak about their week" -- they talk something about specific, like what they did the previous week. This is one of the speech events held 
during the morning meeting (see Figure 2), and Mrs. I tries to make time during the morning meeting so that this event can be held regularly. When a student raises his or her hand and gets picked, he or she comes up to the front of the classroom, faces the class with the blackboard to his or her back and starts speaking. Standing up straight, the student speaks briefly, usually about 1 to 2 sentences, while the other students and Mrs. I listen quietly. There are usually no interruptions except Mrs. I's occasional advice to speak clearer or louder, or to use the proper expression. After the student is finished talking, Mrs. I has the student take two or three students' comments or questions. Once comments and questions are over, the student in front goes back to his or her seat. The same process repeats each time as different students speak about their week.

The most frequent topic of their talk is what the student did during the past week when they were not at hoshuko. Such topics include, for example, his/her tooth having come out at home, having made a snow man at school, or having gone on a family trip. Another prevalent topic is what the students are going to do in the near future, often times right after the hoshuko is over. Examples of this type of topic include: going to a birthday- or other party on that day; so and so is coming after school and sleeping over; going on a trip to Disneyland during the summer break, and so on. And, as mentioned before, the students usually speak about 1-2 sentences. The following example demonstrates a typical presentation. mokuyoh-bi ni, yokigassen o shimashita. $(\mathrm{Ob}-2-10)$

[On (last) Thursday, (I) did had a snowball fight]

Some include in their talk who did what, where, when, with whom, and how in a more elaborate manner, but many students often have only two or three elements in their talk, as seen in the example above. 
Questions or comments are often solicited by Mrs. I, or sometimes by the student speaker. Questions asked often include where, when, or sometimes how the event the speaker described happened, the rather basic information that is missing from the brief talk by a speaker. Some students ask about how the speaker felt, but this question type is less frequent. In the earlier part of JSS's school year, Mrs. I participates more in questioning and commenting, in a way that encourages the student speaker to explain more about what he or she has talked about. As time goes on, and as more and more students voluntarily participate in the questioning and commenting, Mrs. I seems to have less and less involvement, and sits back and listens to the entire process.

As with kiritsu-rei, Mrs. I described several purposes for enacting this speech event. The first is to speak in front of everybody, just like "speech" in an American high school (ITW - T1); and the second is having children practice polite form. The key or tone is peaceful and friendly, and yet, somewhat formal. They have "a proper" way of communicating in this event, which is to use a proper polite language. Observations in the classroom revealed that the children seem to want to be more casual and informal, especially when they are one of the listeners and asking questions. When I was observing this particular event, there was often times an exchange of words, though not necessarily a joke, that prompted some laughter. Mrs. I allowed such incidents to go on, or at least did not discourage the students' witty exchange of words, as long as the words were not mean-spirited, or the way of speaking was not too informal and sloppy. And in such cases, Mrs. I usually did not interrupt the talking of the speaker in front, or questions and comments from the listeners, except for the occasional advice to speak clearer, or to use proper expression, just like she would do with any another presentation, questioning, or commenting during this speech event. 
The form of speech in this event is polite, standard Japanese, and Mrs. I often encourages the students to work toward using good polite expression. For example, if a student speaker finishes talking in the middle of sentence, Mrs. I either fills in the rest or says the correct, complete sentence herself, and then asks the student to say it from the beginning. On the other hand, when some students mention names of places in the U. S., or people's names, whose original pronunciation is in English, and if those students appears to be having a hard time saying them with Japanese pronunciation, she is less vigorous about correcting such pronunciation than she is about correcting incomplete sentences.

This speech event can be identified as story telling or narrative genre. Because the talks the original student speakers perform are often very brief, they become more elaborate stories when the speaker answers other students' and sometimes Mrs. I's questions. In a way, talks in this activity can be seen as corroborative story-telling (Waston, 1975).

\section{III. practice Kanji}

In the first grade alone, the students are supposed to learn 80 Chinese characters, referred to in Japanese as Kanji. Starting around September, right after the students have mastered, or are supposed to have mastered hiragana and katakana ${ }^{15}$, Mrs. I's students start to learn new Kanji in the individual units of the textbook. This event usually happens right after the class does the first "reading textbook aloud" practice (see Figure 2).

This activity, depending on how one looks at it, may be considered a cluster of small events or act sequences. After announcing which Kanji the class are learning

\footnotetext{
${ }^{15}$ Both hiragana and katakana are Japanese syllabaries. These are different from Kanji which is a set of Chinese characters.
} 
and how they are read, Mrs. I slowly writes the model of the newly-learned Kanji, usually on the blackboard, or sometimes on the overhead projector. As Mrs. I writes each stroke of Kanji, she states each stroke number in a clear and loud voice. The students usually watch Mrs. I write quietly from their own seats.

Next, Mrs. I usually has the students raise their right hand and write the Kanji in the air while having them say the stroke order at the same time. Meanwhile, Mrs. I is writing the stokes on the blackboard or the overhead projector. Mrs. I usually writes the same Kanji 2 or 3 times, while the students repeat the same act sequence of writing in the air. Then, Mrs. I has the students practice writing each Kanji several times in the notebook they are supposed to bring from home on each ISS day. This part of the activity usually goes very quietly; however, if the noise gets too loud, Mrs. I instructs the students to practice quietly.

Students who finish writing start lining up in front of Mrs. I's rectangular table, or very occasionally the table in front, and wait for their turn to have their writing checked by Mrs. I. Mrs. I uses a red-colored pen to circle the correct and neat Kanji, while correcting the wrong, or not-so-neat ones by writing over it, writing the models. If a student gets a circle as a whole or circles on every Kanji, he or she does not have to re-write the Kanji. If a student gets even one correction, Mrs. I usually says to the student to "write again." Then those who have to re-write do exactly what they are told, while students who do not need to re-write, are usually told by Mrs. I to read or do other activities that are related to studying. Mrs. I seems to end activities based on the balance between of how many of the children are still working and how much time the class has already spent. During the observation, there were instances where Mrs. I told me, for example, "I am going to give them 15 minutes." (Ob-2-4). Mrs. I usually says:

"hai, yamete kudasai" [Well, please stop (writing/correcting Kanji)] 
"jaa, dashite kudasai" [Now, please turn in (the paper/notebook)]

to signal students to stop practicing and move on to the next activity. The tone of this activity is very formal and quiet.

The goal of this activity, especially from the perspective of Mrs. I, is for the students to learn to write and memorize in order to master Kanji, one of the major written channels of communication in Japan. Memorizing such information as 'how to write certain Kanji" is encouraged. In the JSS, teachers have a clear goal for the students to learn a certain amount of Kanji for their respective grades, knowing that there is little chance for the students to actually use those Kanji in daily life in U.S. society. The number of Kanji that Mrs. I wants her students to learn reflects the number of the "newly-learned Kanji" in the textbook. Consequently, the number of such Kanji reflects the amount of Kanji the first graders in elementary school in Japan are supposed to know at the same age.

Mrs. I uses both oral and written channel to communicate with the students so they can learn how to write correct and neat Kanji. For example, during this event, her students try to master new Kanji, which is itself a written channel, by watching Mrs. I's stroke and penmanship and hearing Mrs. I talk about the sequence one should write for certain Kanji. She also uses nonverbal means of communication for the same purpose by writing big and beautiful model on the blackboard and by having children write the Kanji in the air. Mrs. I conducts the whole lesson in polite, standard Japanese, except for when she mentions, one by one, the stroke number. Some of the most important norms of conduct in this event are to follow the instructions and to write Kanji according to the stroke order. Norms of interpretation are that Kanji is a very important writing system and that it is important not only to write, but also to write correctly and neatly. It is important to be able to read them as 
well. In the textbook, there is a list of newly-learned Kanji, usually at the end of each section, with a demonstration of each stroke number and how they are pronounced.

The genre of this event can be viewed as ritual, for new Kanji is learned in every unit. This activity of practice Kanji is repeated every time new Kanji are learned. "The sacred object" in this case is Kanji as a very important writing system in Japanese. This event, along with almost weekly Kanji homework, and dictation of Kanji where Mrs. I has the students write the Kanji that she is reading aloud from the textbook (see Figure 2), all repeatedly reinforce the importance of acquiring skill to write Kanji competently.

\section{SUMMARY}

In this study, Mrs. I's classroom was identified as a speech community, and it was found that Mrs. I and her students were the primary members of the speech community. Unlike U.S. elementary schools where parent volunteers are present in the classroom, the parents of Mrs. I's students were not present in class during the JSS day. Interviews and observation revealed that the participants belonged to other speech communities as well, and that they oriented themselves to the JSS classroom speech community at very specific times in specific situations during the JSS day.

While a JSS day was identified as a larger speech situation, class periods, Japanese time and mathematics time, and other time segments, such as bread time, were identified as smaller speech situations, which provided more specific context for communicative behaviors. These speech situations were discrete, and were marked by specific classroom speech events, or absence of them. Structure of a JSS day from the students' view was also presented. 
Three key speech events, (1)kiritsu-rei, (2) (students) speak about their week, and (3) practice Kanji, were identified and "thick description" (Geertz, 1973) of the three events was presented utilizing the SPEAKING mnemonic. In the next chapter, an analysis of norms and functions of these three events, norms and functions at the classroom level, and a detailed discussion of these findings are presented. 


\section{CHAPTER V}

\section{DISCUSSION AND CONCLUSION}

The purpose of this study was to discover, describe, and analyze the characteristics of communication patterns that occur in hoshuko classrooms, as well as to understand the meaning that overseas Japanese children make out of their classroom experience. The study sought the prominent communication patterns in a hoshuko classroom and their functions from the native speakers' point of view in this particular speech community. Data were collected through participant observation in a hoshuko classroom, from cultural artifacts, and through interviews with the teacher, some of the students, and some of the students' parents. This chapter presents the analyses of norms and functions of the three events presented in the previous chapter, norms and functions at the classroom level, and a detailed discussion of these findings. The chapter also discusses study limitations and contributions as well as implications for future research.

\section{RESEARCH FINDINGS}

\section{The Three Speech Events: Norms and Functions}

Chapter IV presented the analysis of three carefully selected speech events that occur in Mrs. I's first grade classroom in hoshuko. These speech events themselves represent some very prominent recurring communication patterns, because these recurring events are organized in ways that would best reflect the larger context of classroom activities as a whole, of hoshuko, and of larger JSS schooling 
community. Here I summarize the patterns of these events, and discuss their norms and their functions .

\section{I. kiritsu-rei [stand-up-and-bow]}

Kiritsu-rei occurs between class time and non-class time. In the morning, for example, as soon as Mrs. I comes in and the two otoh-ban who need to be selected for kiritsu-rei and other tasks are selected, the otoh-ban lead the rest of the students and Mrs. I in carrying out morning greeting version of kiritsu-rei. Very specific message forms and contents of act sequences are enacted, and everybody carries out kiritsu-rei in unison. The same speech event, in an almost identical manner, happens in the majority of classrooms in Japan, but not in U. S. classrooms. Several language classrooms in the U. S. that teach Japanese adopt the speech event as a part of their routine.

There are several major norms for this activity. First, all the participants are supposed to follow the schema of the act sequence very rigidly. Set phrases and a set form are supposed to be followed by all the participants each and every time. Mrs. I's students are supposed to know which variation of the phrase should be used at which time. The message form, including the non-verbal aspect, of kiritsu-rei is very fixed. If the participants violate these norms and do it in a "sloppy" way, it calls for doing the act sequence again from the beginning.

Second, everybody is supposed to carry out the act sequence in unison. When doing kiritsu-rei at the beginning and end of class time, every participant in the classroom is supposed to do the non-verbal act sequence of standing up, standing straight, and bowing all together in unison. When doing kiritsu-rei as part of the morning and parting greetings, voices should be in unison as well. When somebody violates this norm and deliberately delays or quickens his or her actions, either Mrs. I 
asks the otoh-ban to stop the act sequence and start again from the beginning, or the otoh-ban stop the act sequence voluntarily, until the person who is distracting catches up or slows down so that everybody can do kiritsu-rei at the same pace.

Third, the otoh-ban must lead this activity. The otoh-ban are supposed to be initiators of this event, and Mrs. I usually let them lead the event without any interruption when things are done correctly. As described above, otoh-ban often times should stop the act sequence and wait, or start again from the beginning, when proper forms and contents of the procedure are not followed, and otoh-ban have the power to do so. Most students consider leading kiritsu-rei as at the top of the list of otoh-ban's task description (see p. 65). From my personal experience, the roles of otoh-ban in this activity seem to resemble the role of "helpers" in U. S. classrooms when they are leading the "Pledge of Allegiance." The children, called "helpers" in some U. S. classrooms, stand in front of the class, body facing toward the flag with their right hand on their chest, but face looking back at the rest of the class to make sure everybody in the classroom is standing straight with their right hand in the 'right' place, and then say "ready, begin."

There are several functions for doing kiritsu-rei. One of the major functions, from Mrs. I's point of view, is the 'marking' function. The act sequence of kiritsu-rei serves as a marker that defines the boundary of class time (morning meeting and before-going-home meeting included), and differentiates such class time from break time. Mrs. I believes that doing kiritsu-rei is having "kejime". Hendry (1986) describes the concept of kejime as "the teaching of 'discrimination' or 'distinction' " (p. 84); a person with a strong sense of kejime has the ability to distinguish between good and bad or the ability to distinguish between various activities, such as eating and playing. The concept of kejime is valued in Japanese culture. When a Japanese person comments "X does not know when to play and when to study," meaning that 
person $\mathrm{X}$ does not have kejime, that usually has a negative connotation. On the other hand, phrases like "kejime o tsukenasai [draw a clear distinction]" is often used to tell others to have a clear distinction between what they can do in a certain situation and what they cannot.

There are some rules that specifically apply to class time. Mrs. I's students 'correctly' told me some of the rules: "do not walk around (unless instructed)," "do not go to the bathroom," "do not get a drink," and "do not go sharpen pencils" (ITWCh 5). In other words, standing up and leaving one's seat or the classroom during the class without the teacher's instruction is considered improper in Mrs. I's room. Behavior such as "go sharpen pencils," which seemingly relates to studying is not allowed during class time. The assumption is that sharpening pencils is a pre-class activity and every student comes to class all prepared. The students know once kiritsu-rei is done and the class has started, they are not allowed to do certain things until they do the kiritsu-rei at the end of the class. Kiritsu-rei, therefore, becomes a symbolic activity that signals the beginning or end of the more rule bound time segment called class time.

Another major function of kiritsu-rei is to enhance cultural identity as Japanese. Kiritsu-rei is "something Japan has as customs and will be needed when he or she goes back to Japan" (ITW-T1), and Mrs. I feels strongly that the students should acquire the customs, especially the part of bowing as a Japanese manner. Children, on the other hand, may not necessarily identify most strongly as Japanese, but more as a member of the speech community of hoshuko, or more specifically, of Mrs. I's class. 


\section{II. "(Students) speak about their week"}

"(Students) speak about their week" (hereafter referred to as "(students) speak") is held during the morning meeting. Three students, one by one, stand in front of the classroom and talk briefly about an event that happened in the past week or an event to happen in the near future. Questions and comments from the other students or Mrs. I follow.

"(Students) speak," in certain ways, resembles "sharing time," a class activity that can be seen in many U. S. classrooms in which children do the story-telling (Michaels, 1981; Sharing time, 1992). General characteristics of sharing time, such as children having the choice as to what to talk about, a student speaker receiving questions or comments, usually from the teachers and sometimes students, can be applied as well. The frequent topic of the talk in "(students) speak" is about some past event or some event in the future, which is one of topic usually chosen for "sharing time" as well.

Some noticeable differences between "(students) speak" and "sharing time" is that students' presentations in "(students) speak" is usually a lot shorter than presentations in the "sharing time" that I have observed or those described in some studies (Michaels, 1981; Sharing time, 1992). Also, children do not bring physical objects during "(students) speak" time in Mrs. I's class.

From Mrs. I's point of view, the primary purpose of this event is to speak in front of everybody, and to have children to practice a standard Japanese polite form. Norms of interactions when speaking in front of everybody are to stand with good posture and to talk in a clear voice, in a polite Japanese expression which includes using complete sentences instead of uttering a cluster of words as the students might in their "everyday language". Telling a long story is not one of the norms in this 
speech event. As listeners, the rest of the students do not interrupt the speaker and listen quietly.

Sharing time (1992) claims that sharing time, by its ritualistic nature, reinforces and reaffirms "a specific type of talk," which is an accurate, descriptive, and truthful referential talk about the object or subject a student is referring to. Michaels (1981) contends that sharing time serves as an opportunity for a teacher to help students focus and structure their discourse and put all meaning into words. With "(students) speak," the teacher is still trying to solicit a certain way of storytelling, but at more of a surface level: to make sure that students' talk includes the language elements that make the phrase "polite form," to make sure that students follow the nonverbal aspect of the norms for this event, which is to stand straight and talk in loud and clear voice. Hendry (1986) describes that a speech activity in a Japanese kindergarten serves as a practice ground for speaking in front of class in formalized language, which is "a good preparation for [Japanese] primary school" (p. 137). Functions of "(students) speak" seem to be similar to that of the speech activity in a Japanese kindergarten described above.

The author in Sharing time (1992) also claims that there are also other goals for sharing time; to "[honor] the construction of personhood in the form of 'Self-asAutonomous-Person' " (p. 17) and to help children develop sense of respect for the authority figure. Some of the same communicative acts described by the author which enhances students in a U.S. classroom to foster the sense of independent person (such as singling out one speaker at each time) can be seen as a part of communicative pattern in "(students) speak." However, it was not expressed by Mrs. I as one of the goals and the intentions of the event. Considering that the main purpose of speech event is to help children to obtain formalized ways of speaking, both verbally and non-verbally, the idea of fostering the sense of independent person 
seem to go counter to what "(students) speak" are trying to accomplish. With the notion of respecting authority, again, some similar communication patterns can be seen in both the U. S. classroom in Sharing time (1992) and Mrs. I's classroom, such as the teacher in both classroom settings executing their ability to correct, discipline, and praise students during these activity. Nevertheless, the notion of fostering children's sense of respecting the authority was not identified as a major goal by Mrs. I.

This event serves as an opportunity for the teacher to have students practice speaking polite language and speaking in front of people. As for the students, they seem to enjoy having an opportunity to talk about events in their lives, as well as questioning and commenting casually to their friends. Student speakers are able to use a part of class time to let the class know what was/is going on in their lives. Listeners can ask some questions of an informal nature, or have a witty exchange of words with the speaker, as long as it is done in polite language. When some speakers say the name of a place or people that are usually originally English, the students are not as readily corrected by Mrs. I as they would be if they spoke in incomplete sentences or if they used "everyday language" instead of polite expressions.

\section{III practice Kanji}

Practice Kanji is held in the Japanese time, where Mrs. I instructs and has her students learn and practice newly-learned Kanji. Mrs. I first shows the model of each Kanji by writing on the blackboard or overhead projector, stating the stroke order as she writes. Meanwhile the students watch and listen to Mrs. I quietly. Next, Mrs. I has her students write those Kanji in the air several times and has them say the stroke order while she writes them on the blackboard or overhead projector and joins the students in saying the stroke order. The students are supposed to say the stroke order 
loud and clear, as "ichi, ni, san, .... [one, two, three...]," while drawing Kanji in the air. They should do both hand motion and counting in unison. Students then practice Kanji in their notebooks very quietly, following Mrs. I's instruction. When students finish writing in the notebook, they go to Mrs. I to have their writing checked. When Mrs. I recognizes the students' writing as correct and neat, those students do not have to write again. If Mrs. I thinks the students' writing is not correct or not so neat, those students have to re-write. Although the process may not be identical, the activity of practicing Kanji in a similar fashion can be found in schools in Japan.

One of the most important norms in this activity is that students should strive to write correct and neat Kanji. Students should ideally be able to write Kanji they learned correctly and neatly by the end of the activity, which usually lasts about 20 minutes all together. Some other important norms are closely related to this first norm. For example, the students are supposed to closely follow Mrs. I's instructions during the whole process. Consequently, the students practice the same Kanji several times, not including the re-writes that some students have to do. If some students are not writing Kanji in the air when they are supposed to, Mrs. I stops the process and tells the students that their behavior is not $\mathrm{O}$. K. The tone of this activity is supposed to be very serious and quiet, especially when they are writing. If the noise gets too loud, which is very rare, Mrs. I reminds the students that "this is the time to write, and not to talk" (Ob-2-24) and usually the students quiet down quickly. The norm of interpretation behind all these interactions is that being able to write Kanji is very important, and it is even more important to write Kanji competently. To be able to write Kanji competently means not only to simply write them, but also write them correctly and neatly. For adults, poor handwriting is often associated with low intelligence or lack of manners to the readers of that writing. Writing Kanji with the right stroke order is also an important part of writing Kanji competently. 
The activity has the function of reinforcing the importance of Kanji as a writing system. Mrs. I uses both oral and written channels to reinforce the idea that it is important to be able to write Kanji, and it is also important to be able to write them correctly and neatly. For students, the importance of this activity seems to be very clear. During the interview, this activity was mentioned by many students ("Kanjio narau" [learn Kanji], "Kanji o oboeru" [memorize/master Kanji] ) as one of the first activities that they can think of. Several students also mentioned "Kanji" as the first response to "what do you think you learn at hoshuko?" (Q7 in interview guide; see Appendix D), suggesting that they have a very strong impression that Kanji is one of the major things they learn at hoshuko.

\section{At the Classroom Level: Norms and Functions}

Some of the recurring patterns demonstrated across the three events described above are also seen in many other speech events as well. The students also gave the researcher their descriptions of "shoulds" and "shouldn'ts" in JSS classrooms.

One of the overlapping norms of speech across various speech events is "speaking Japanese only." This pattern can be seen again and again during a JSS school day, and many children identify the 'Japanese-only rule' as "something you should do in school." (ITW - Ch 3). During the interview when the researcher asked, "what language do you usually use at hoshuko?" most of the student informants quickly answered, "nihongo [Japanese language]." Those who did not use the word "nihongo" as their response, either gave concrete examples of what kind of things they would exactly say in the school situation (in Japanese), or started to talk about the different forms of language (in Japanese) that they use during the course of a JSS school day. In both cases, the student informants seemed to assume that the researcher also understood that it was Japanese that they were talking about. 
The "Japanese only" rule is also one of the very few rules that is applied beyond class period into the break time. If some students speak in English during lunch time, for example, Mrs. I immediately says "nihongo de hanashite kudasai [please speak in Japanese]." The students often keep their voices very low in such situations, suggesting that they are speaking English and know that there is a rule not to, and they speak in low voices because they do not want to be caught by Mrs. I violating the rule and have to be corrected. Regardless of their competence and fluency in Japanese, which seems to vary depending on the individual, it is still expected that the content of the message is to be communicated in Japanese.

The "Japanese only" rule applies to many of the loan words which are imported from other languages, including English, to Japanese (that is, what is called "Japanized English.") In Japan, many people use such words with Japanized pronunciation that is different from that of the original word in English. The JSS students have to know which English words are in fact "Japanized English" used in Japan. The students can use such "Japanized English," but only with the Japanized pronunciation. Considering the fact that many of the students have been in the United States longer than they had been in Japan, loan words may be very hard to identify. One student, who is a child of an international marriage, explained that the word "cup" is one of those words, and a regular American English pronunciation of that word would be improper in the JSS classroom, while Japanized pronunciation, /koppu/, is the "proper" way of saying it (ITW - Ch 3). This student commented that English pronunciation of some Japanized English almost "comes out sometimes", and that, although there are such close calls, he "can keep" the rule (ITW -Ch 3).

The norms of speaking regarding the form of speech that specifically applies during class time is "to speak a polite, standard Japanese." Some students described the way they should talk in class as "teineigo o tsukau [use 'polite language']" (ITW - 
Ch 9), "kichitto hanasu [talk properly]" (ITW - Ch 1), and "use 'desu,' 'masu,' and 'mashita' " (ITW - Ch 10). ${ }^{16}$ One of the students pointed out that this way of speaking is different from the way of speaking that they use in the playground, stating "oyasumi-jikan wa hutuu ni hanasu [we talk in usual way during recess]." The other two gave me concrete examples of how they speak in the playground: "onigokko shivooyo [let's play onigokko (Japanese game of tag)]" (ITW - Ch 1); "asoboovo [let's play]" (ITW - Ch 10). Both shiyoovo and asobooyo are examples of what Mrs. I characterizes as "everyday language" (ITW - T1), a style of language one uses while talking to in-group members in an informal situation, not a polite form. The students who did not identify "speaking a polite, standard Japanese" as a rule during the interview, demonstrated their understanding of the rule during the observation: The students either kept using polite language while they were in class, or immediately "corrected" their "everyday language" to polite language once it was pointed out by Mrs. I that they were not using the polite language.

The "speaking a polite, standard Japanese" rule is particularly rigidly monitored by Mrs. I during "(students) speak about their week," and immediately corrected if students started using "everyday language" during this speech event. During other speech events in "Japanese time" and "mathematics time," some students constantly keep the polite form, while others sometimes speak in less formal, less polite, incomplete sentences by giving "one-word" answers instead of complete sentence answers. Mrs. I often does not necessarily correct the students each time in such situations, but makes sure Mrs. I herself says, replies, or asks in polite, formal,

\footnotetext{
16 Desu is a copula, and masu is a form of verb ending in Japanese. (Mashita is the past tense of masii.) These elements indicate that the speaker "is being less direct and more formal as a sign of deference to the person addressed rather than talking directly, intimately, familiarly, abruptly, or carelessly" (Jorden and Noda, 1987, p. 32). In this thesis, because the use of desu and masu indicate "teinei [politeness]," I will call them "polite language" or "polite form," which may not be the same as honorifics.
} 
complete sentences. Based on my observation, toward the end of the school year, there were less and less incidents in which students had to be corrected because of their use of "everyday language" in the classroom.

Frequent use of the written channel seems to be another important, overlapping norm. Written language is often used during communication in the classes. The teacher seems to use the written channel to repeat or summarize the message content that is communicated orally. The students' use of the written channel occurs usually at Mrs. I's instruction. In such cases, the primary purpose of students using the written channel is often not to communicate the message content of the words or phrases, but show that they can write certain words or phrases.

As described previously, in learning Kanji it is important not only to be able to write correctly but also to be able to write neatly. This expectation applies to the entire writing system that Mrs. I's students learn during the school year, including hiragana and katakana, two other writing systems in Japanese. How one writes Kanji, with correct stroke order, for example, is as important as just being able to write them correctly with all the strokes present.

\section{"Hidden Curriculum" and "Cultural Transmission"}

Such norms, both at the speech event level and at the classroom level, seem to suggest that there exists a "hidden curriculum" (Jackson, 1968) in Mrs. I's classroom. A "hidden curriculum" is "a pattern of expectation and relevant behavior" (Spindler, 1982, p. 237) in educational settings, often unstated but recognized by the participants. Pratt (1994) defines hidden curriculum as "conscious and unconscious intentions reflected in the structure of schools and classrooms and the actions of those who inhabit them" (p. 29). In Mrs. I's classroom, doing the class activities as close in form as possible to the activities that are held in schools in Japan seems to be the 
primary hidden curriculum. Kiritsu-rei and practicing Kanji are typical examples of Mrs. I teaching her children both content and form of what the students would learn if they were in Japan. Such curriculum seems to be negotiated from time to time, however, by: inclusion of some of the activities which are not typically included in elementary school classrooms in Japan, such as "(students) talk about their week;" the experiences and understanding that both Mrs. I and her students have regarding school activities in general, which may be shaped greatly by the experience both of them have at U. S. classrooms during the weekday; or a lack of influence from schooling experience in Japan. Some such negotiations occur through interactions between Mrs. I and the students. Some rules under the curriculum are negotiable; other are not. What seems to be "non-negotiable" curriculum seems to be the ones the teacher feels it important for students to receive. Mrs. I places strong emphasis on doing kiritsu-rei and practicing Kanji in a "right" way, and there is very little flexibility with the rules of interactions for these events.

By having such "hidden curriculum", many of the classroom activities seem to serve as ways for Mrs. I to pass on some of the values which are "important to have as a Japanese" and which students will "need when they go back to Japan" (ITW - T1). Mrs. I gave me an example of $r e i$ [bowing], stating that doing a deep bow "is, if you are a Japanese, culturally expected when you go back" (ITW -T1), and that she wants to have those "customs" last in the mind of the children by repeating them several times during a JSS school day. In a way Mrs. I is simulating the way it is done in Japan so that she can transmit some of what she thinks is important in Japanese norms and values.

Porter and Samovar (1994) claim one of the characteristics of culture is that "culture is transmittable" (p. 12). Barnlund (1994) contends that every culture "attempts to create a universe of discourse for its members, a way in which people 
can interpret their experience and convey it to one another" (p. 32), and that this "universe of discourse" is being transmitted "to each generation in part consciously and in part unconsciously" (p. 32).

Spindler (1958) and other scholars claim that educational settings, especially the classroom, are one of the places where culture is transmitted, and describe teachers as transmitters of culture (Spindler 1958, 1982; Spindler and Spinder, 1990; Gearing and Epstein, 1982; Wilcox, 1982a, 1982b). Cultural transmission in the classroom is sometimes done purposefully and explicitly, but often times it is done in more subtle ways.

In the case of Mrs. l's classroom, the teacher, Mrs. I, is clearly aware of being a transmitter of the culture to her students. Although it is hidden in terms of explicitness to the children in the classroom, there are very deliberate acts on the part of Mrs. I to pass on some of what she thinks are important values for Japanese children, as it was expressed by Mrs. I during the interview. The concept of kejime in kiritsu-rei, certain ways of talking in front of people in Japan, and the importance of stroke order in Kanji are all important norms and values in Japan, which are often taken for granted by Japanese people in Japan, but are carefully transmitted in the case of Mrs. I's classroom.

The intention and effort of transmitting culture becomes occasionally explicit when some of the rules are violated. For example, during my observation phase, when some of the students started walking up to the teacher to ask a question, she told them to go back to their chairs and raise their hand for the question, and added "this is not an American School" (Ob - 6-8). 


\section{Children's Ways of Speaking}

Children: The cooperative participants of classroom communication. In discussing the concept of cultural transmission, Spindler (1982) cautions fellow researchers to remember that:

... children at all ages place their own constructions on reality. Their behavior is not simply childish translation of adult norms or patterns of behavior. It is a result of a complex interaction of child culture, adult culture, individual striving, and situational culture (the rules, expectations, and assumptions that emerge and stabilize in any continued social setting).... we need among a myriad of other things, to study the culture of children, including the constructions they place on the reality that we adults think we know and are trying to teach them. (p. 312)

In this study, the students articulated some of the norms of the classroom in interviews. They also demonstrated during classroom interactions those norms for the three selected events, among other norms. Fujisaki (1986) refers to the research findings of Mehan (1982) and Brause and Mayher (1984) and claims that children are not only being passive in executing the routine of classroom activities, but being active in making classroom activity go smoothly. As it is shown most illustratively in the kiritsu-rei activity, the students' cooperation helps the classroom interactions proceed as the teacher intended and, consequently, helps the teacher transmit what she thinks is important norms and values to them.

Another cultural value that surfaced in this study is concept of kejime, which is the ability to distinguish between good and bad behaviors or to distinguish one situation from another, such as study and play. There are, as previously noted, rules that specifically apply to class time, such as "do not walk around (unless instructed)," 
"do not go to the bathroom," "do not get a drink," and "do not go sharpen pencils." (ITW-Ch 10. See p. 76) When the children talked about such rules, they often used the phrase "... no toki wa [when ..., while ...]. For example, one student said, "benkyo no toki wa oshaberi o shinai [do not chatter while studying]" (ITW - Ch 4). The same phrase was used by the students to specify when to use polite language and when to use "everyday language." These references to situations indicate to me that the students understand that these rules do not have to be kept all the time, and that the important thing is knowing when it is appropriate to apply the rules. This is a good example of how one of many very important values is successfully transmitted by Mrs. I to the children and fostered though classroom interaction by the cooperation of the children.

\section{Children's code-switching ability.}

Saville-Troike (1989) claims that children in multilingual speech communities "must, in addition to multiple language codes, acquire skills in switching and more complex rules for appropriate usage" (p. 261). Although main focus of this study is one aspect of children lives called hoshuko, it is important to remember that hoshuko is one social setting that the children participate in with a certain set of rules and norms that are likely to be different from those in other settings.

Being able to keep the "Japanese only" rule is remarkable, considering the need to shift between different languages so frequently in the lives of these children. Even though it was only a small part of the children's lives that I was able to glance at through the interview, their descriptions regarding their language use in everyday life showed me how complex their social world is in terms of which language to choose when talking to other people, and that the rules are not always cut and dry. Most 
students used the word "iroiro [(it) varies]" to start their description of what languages they are use "outside" the JSS.

One good example is the response from a child from a two Japanese-parents household. This student explained that at her American school with her Japanese friends, she speaks in Japanese; with other friends or other times, she speaks in English. She went on to describe how the this works for her:

But sometimes, I almost say "Sensei" to a U.S. school teacher ${ }^{17}$.....

During recess when playing with American friends, (I) use English...

Even with Japanese friends, I sometimes say things like,

$$
\text { "okkei }[=\mathrm{O} . \mathrm{K} .] ! " \quad(\text { ITW }-\mathrm{Ch} 9)
$$

When asked about what it would be like at home, the following excerpt is what she said:

Child: Sometimes (English) comes out suddenly (from my mouth) ...

Interviewer: For example......?

Child : Like, "okaasan, dinner choodai [mother, please give me "dinner"]"...

Interviewer: And what does she say?

Child : (I) am usually told, "speak in Japanese." （ITW - Ch 9)

This student has a sister who goes to the same school. She described how English "comes out" when she is with her sister:

When we are fighting, bad words like "stupid" come out. When we make up, we say "we are friends." ～(ITW - Ch 9)

\footnotetext{
${ }^{17}$ The literal meaning of the Japanese word "Sensei" is "teacher." When students in schools in Japan call their teachers, they would put the word "Sensei" after the name of the teacher (usually their family name). This is the way the JSS teachers are called by their students as well. So Mrs. I is called, for example, "I-sensei."
} 
When asked about what it is like with her father, it turned out that her father sometimes uses English as well, as in the following excerpt, when she was told by his father to go to bed when she did not want to:

Child: When (I am) mad, I ask him, like, "why?"

Interviewer: What does your father say then?

Child: He sometimes says, like, "go to bed," too... (ITW - Ch 9)

The use of different languages in different social situations is the pattern with the children of international marriages as well. One student described his choices of language over the course of his daily life:

It is Japanese (that is used) at home ... With my dad, it's in English....

In my father's car on the way to JSS, we speak in English. He always takes me to JSS.... With so and so [name of another child from a international marriage in JSS], (we) use Japanese, ju-u-ust a little bit of English, too.... (ITW - Ch 3)

It should be noted that his father, who is an English speaking U.S. native, speaks Japanese very well, and had talked with me in Japanese several times in Mrs. I's classroom.

At JSS, they orient themselves to the speech community of JSS and try to keep the "Japanese only rule," among other rules. Outside class time, the students try to check each other to make sure that these rules are kept; they become their own 'peer check' system. The next description by one student about his experience in the playground illustrates that the "Japanese only" rule is reinforced beyond class time by a peer group.

The student described how he was discouraged from using English in the JSS playground. This student came to the U.S. and transferred to JSS in the middle of his first-grade year. He said that it was hard to speak in English in the beginning, but as 
he became better and better at using English, he really wanted to use English. When he said, in English, "I am going to come to your house!" (ITW - Ch 6) in the JSS playground, another student told him not to use English. Moreover, even when he said "baai! [Japanized-English word for "bye"]" his friends replied by saying, "Aaa, eigo, dame! [Ahh, no English!]" This student's tone of voice when he was talking about this particular portion of the incident seemed to suggest that he was surprised to find the "Japanese only" rule so strict that a word like "baai," which is usually used by Japanese natives in Japan as a loan word, would not be allowed or would be considered "not speaking Japanese."

At the beginning of the year, this rule seems very hard for some students. This seems especially true to some of the students from international marriages, not because of sheer cultural background, but because they, as the result of the family situation, have limited experience in communicating with other people in Japanese outside the school setting. However, there were other students from international marriages who were able to follow this norm well, if not better than other students with two Japanese parents, who can be assumed to have more opportunity to speak Japanese at home. How well, or how poorly, the students are able to code-switch is another important factor in keeping this rule. Some of the students whom I observed were very quiet, and seemed to have trouble finding a Japanese word when they were asked to speak, for example, in the classroom. In such cases, by staying quiet, instead of using English, they kept this "Japanese" only rule.

\section{Perceived Purposes of the JSS}

Considering that purpose is a strong determinant for people's ways of communicating (Hymes, 1972), it is insightful to see how a sense of purpose from different standpoints in the community helps shape the interactions in a certain 
setting. Hymes (1972) describes, as a part of the SPEAKING mnemonic, that there are two kinds of purposes: what he calls "ends in view (goals)" (p. 62), which refers to the purpose from those who are engaging in the events, and "ends as outcomes" (p. 61) which refers to the purpose from a community standpoint, the other community members. Hymes (1972) emphasizes that "ends in view" and "ends as outcomes" need not be identical to each other, but that they are both powerful determinants of the form of speech events.

In the case of Mrs. I's classroom, there are clear "ends as outcomes." The purpose of hoshuko like ISS was 'for the students to be able to catch up when they go back to Japan.' Mrs. I recognizes the purpose at hoshuko level and states that even though there are more students now who are not going to Japan to live the primary purpose of the school is still "to prepare the students to go back to Japan" (ITW -T1) and that she wants to make sure that her students are ready.

Even though some students did not know that they were enrolling in JSS until the last minute when their parents told them about the school, by the end of the first year some of the students had a clear idea that the school is mainly for the student to be able to catch up when they go back to Japan. When asked why they go to hoshuko, some of their responses were "because, (I) am now in the U. S. and, when, when (I/we) go back, the students in Japan may have learned much more about math, for example, that we have at American schools" (ITW - Ch 9), "because I can keep up with (other children / school work) when I go back" (ITW - Ch II). Still, many of the students also answered it is "to study Japanese (language)" (ITW -Ch 2) "to not forget Japanese" (ITW - Ch 5; Ch 6). One student also mentioned that he goes to the school to meet different friends (than his friends in the neighborhood or U.S. school), and even though other students did not mention it as their "purpose," there were many 
who listed playing different games with friends as "their typical day" at JSS, some as the first things they said before they mentioned classroom activities.

Interviews with parents revealed there was yet another point of view that shapes the JSS school life and what it means to "send the child to JSS." The majority of the parents expressed that their primary concern behind sending their children to JSS is for them to be able to be competent in school in Japan. This sentiment was shared by most of the two-Japanese-parents households, but some parents with an international marriage background also wanted their children to have the ability to do all right in schools in Japan, because they anticipate the family may go to Japan and live, at least for a while, at some point in their children's school life.

Many parents mentioned becoming competent in two languages and becoming 'bailingalu' [Japanized-English for "bilingual"]. For some, hoshuko gives their children just that by strengthening Japanese, while for others, bilingualism is achieved by participating in the English-speaking, U. S. society and strengthening English. Hoshuko gives their children the ability to retain Japanese. There was even one student who articulated, when answering why she thinks she goes to hoshuko, that " it is better to learn 'both' (languages; Japanese and English) because you can use them when I grow up" (ITW - Ch 1).

\section{SUMMARY OF FINDINGS}

Close analyses of the three key speech events revealed that those events were organized in ways that would best reflect the larger context of classroom activities as a whole, of hoshuko, and of larger ISS schooling community. The concept of kejime in kiritsu-rei, the proper ways of talking in front of people in Japan, and the importance of stroke order in Kanji were among those norms that were identified. 
At the classroom level, rules and norms, such as the "Japanese only" rule, the "using standard, polite Japanese" rule, and the frequent use of written channels as well as specific ways of using written channels were identified. It was also found that the primary "hidden curriculum" in this classroom appeared to be "to enact the activities as close in form as possible to the ones that are enacted in schools in Japan." For the teacher, simulating the Japanese school classroom in Japan served the purpose of transmitting cultural norms and values that she thought were important for the students when (or if) they returned to Japan.

The teacher was very aware of and active in transmitting cultural values and norms, by setting the aforementioned norms and reinforcing them through her interaction with the students in the classroom. As for children, they were able to identify the norms and rules and many executed them competently, or became competent gradually. Children were cooperative and active participants, and they fostered the cultural norms and values identified in this study through their interaction with the teacher as well as among themselves.

The perceived main purpose of hoshuko, that is, preparing the children for when (or if) they move back to Japan, was understood by the teacher, children and parents of these children in their own ways, and their collaboration helped shape the classroom interaction.

\section{STUDY LIMITATIONS AND CONTRIBUTIONS}

My data processing skill turned out to place an obstacle in my way when trying to insure reliability and validity. It was often difficult for me to do a speedy transcription while trying to catch everything on the tape-recording. In the end, I made an adjustment and limited the places I transcribed and translated (Seidman, 
1991). If I were to do things differently, I would employ a trained transcriber who was bilingual in Japanese-English, and have him or her transcribe while I oversaw and checked with the transcriber. This strategy would enhance the speed of transcription and I can still have control over the quality of the transcription.

The second limitation is methodological. "The observer's paradox" (SavilleTroike, 1989) is an innate issue for participant observation. The effect of my presence on participants in the classroom was even greater than some other settings because of the closed nature of the hoshuko setting.

The third limitation is the sample size of this study. This is an innate limitation in case studies. This research involved only one hoshuko, and only one classroom in hoshuko; therefore, the findings from this research cannot be claimed as true about hoshuko in general, or hoshuko classrooms in general. This study must be considered as a case study, and it will require many more studies in different hoshuko and different classrooms in hoshuko before external generalizations can be made.

Fourth, because of the uniqueness of the cultural group selected for study, the aim of my research is geared toward "generalization within the group" rather than "generalization across the groups" (Philipsen, 1982). This study focuses on a specific group of Japanese overseas children who go to hoshuko, and will not be applicable to Japanese children who attend only American local schools or those who attend nihonjin-gakko [Full-time Japanese schools]. It may not be applicable to children in the hoshuko in other parts of the world, for the historical and social context of the school may differ considerably.

However, the last two limitations mentioned above can be looked at as a strength as well. Although I was able to look at only one classroom in a hoshuko for this study, my detailed "paper trail" may be able to be used for later comparative analysis. Also, because I focused on members of a very specific cultural group in a 
very specific situation during the entire research process, I was able to go in-depth and delineate very complex communication phenomena and their functions. As a first ethnographic study that focused on classroom interaction in hoshuko setting, this study contributed in analyzing classroom interaction of a culturally complex setting.

\section{IMPLICATION FOR FUTURE RESEARCH}

Several possible directions for future research have been identified through the course of research. First, ethnographic research with different hoshuko classrooms, or different hoshuko, needs to be investigated to determine if some of the findings in this study will be found in other hoshuko classes. In other words, if commonality exists not only "within the group" but possibly across the groups" it will need to be uncovered by future research.

A study that includes communication at home, like Heath (1983) and Philips (1983), would be able to explore the aspect of the context of school communication that was not examined in this study. Data for this study regarding students' communication at home were only through interviews with the students and the parents of the students, and treated only as contextualizing information. I found, however, there were some children who were able to acquire the communicative competence very early on in their first year, while it seemed more difficult for others. I also discovered that such competency was not necessarily determined by their cultural background. I believe it will be useful to find out the link to home communication and school communication and see if there is a possible "townspeople" (Heath, 1983) type of community with the speech community that was identified for this study. 
Another possible direction for future research is comparative studies with other Japanese-language related classrooms -- such as nihonjin-gakko [Japanese fulltime school], or a language immersion program teaching Japanese. This type of study will be able to explore how, or if, doing similar activities in terms of learning school subjects in Japan, but with different contexts, purposes, or participants makes differences in the interactions of the participants in the respective classrooms.

There are two methodological recommendation that arose out of this research process. The first one is the field issues. I did not go through one of the important gatekeepers, Mrs. H, until very late in this study, which would have jeopardized the access to the research field, had Mrs. $H$ not been very understanding and willing to work with the researcher. I would recommend to the future researchers that, even after they go through one gatekeeper, to ask the people to make sure that their field entry is accepted by the every important channel. As Corsaro (1981) illustrates, there are different gatekeeper(s) to different field.

Secondly, information gathered through the pilot study, which consisted of mainly observations and field interviews of a class at a U. S. elementary school, was significantly useful in gaining insight about the culture of a U. S. elementary school. Such insight helped me to analyze the data gathered in this study on hoshuko and compare it to U. S. elementary schools, not only based on the literature, but also on my first hand experience. I would recommend that Japanese researchers who attempt to conduct research in hoshuko, if possible, conduct an observation and field interview in a U. S. school.

For teachers and practitioners who come in contact with overseas Japanese children and/or returning children, it may be useful to take the ethnographic approach in looking at the situations that surround these students before imposing their assessment of the situation on the children. Many of the students who participated in 
my study showed a high level of communicative competency in a very culturally complex setting. However, when such students move to another culture, including 'going back' to Japan, they are likely to have a struggle, not because they do not have the ability to be communicatively competent, but because they have acquired a way of speaking in the classroom and norms behind such speaking, which are likely to be different from the speaking system in another culture.

\section{CONCLUSION}

Based on the ethnographic perspective, this study explored the patterns and norms for interaction in a hoshuko classroom setting, as well as the participants' socially constructed reality of hoshuko schooling. Investigation of the classroom interactions in this study revealed that each classroom activity had a certain set of norms that the teacher set and reinforced, and many students were able to follow such norms competently or with growing competency. Also, the participants in this hoshuko classroom interacted with each other according to the "hidden curriculum" of the class activities, which was 'to enact the activities as close in form as possible to the ones that are enacted in schools in Japan.' Such hidden curriculum was negotiated between the teacher and the students, and many students were active participants in receiving the transmitted values and fostering them through their participation in classroom interaction. There was indeed a speech community which drew on particular communicative resources and operated with a set of norms. In the case of Mrs. I's classroom, both teacher and students were active participants in their own ways.

In Japanese society, various images of overseas Japanese children have been portrayed over the years, some positive and others negative (Sato, 1995), but 
children's actual situation in the host country is rarely portrayed in their own words. It is time to get to know their life from the children's point of view, and see the very competent side of these children. 


\section{References}

Albrecht, T. \& Ropp, V. (1982). The study of network structuring in organizations through the use of method triangulation. Western Journal of Speech Communication, $46,162-178$

Anderson, J. F. \& Powell, R. (1991). Intercultural communication and the classroom. In L. A. Samovar \& R. E. Porter (Eds.), Intercultural communication: A reader. Belmont, CA: Wadsworth.

Banks, A. \& Banks, S. P. (1991). Unexplored barriers: The role of translation in interpersonal communication. In S. Ting-Toomey \& R. Korzenny (Eds.), Cross-cultural interpersonal communication. Newbury Park, CA: Sage.

Barna, L. M. (1994). Stumbling blocks in intercultural communication. In L. A. Samovar \& R. E. Porter (Eds.), Intercultural communication: A reader. Belmont, CA: Wadsworth.

Barnlund, D. C. (1989). Communication styles of Japanese and Americans: Images and realities. Belmont, CA: Wadworth Inc.

Barnlund, D. C. (1994). Communication in a global village. In L. A. Samovar \& R. E. Porter (Eds.), Intercultural communication: A reader. Belmont, CA: Wadsworth.

Bauman, R. \& Sherzer, J. (1974). Explorations in the ethnography of speaking. Cambridge, MA: Cambridge University Press.

Bauman, R. \& Sherzer, J. (1975). The ethnography of speaking. Annual Review of Anthropology, 4, 95-119.

Berger, P. \& Luckmann, T. (1966). Social construction of reality. Garden City, NY: Doubleday. 
Blumer, H. (1969). Symbolic interactionism: Perspective and method. Englewood Cliffs, NJ: Prentice-Hall.

Braithwaite, C. A. (1991). Cultural communication among Vietnam veterans: Ritual, myth, and social drama. In R. Morris \& P. Ehrenhaus (Eds.), Cultural legacies of Vietnam: Uses of the past in the present. Norwood, NJ: Ablex.

Brislin, R. W. (1986). The working and translation of research instruments. In W. J. Lonner \& J. W. Berry (Eds.), Field methods in cross-cultural research (pp. 137-164). Newbury Park, CA: Sage.

Bulmer, M. (1979). Concepts in the analysis of qualitative data. Sociological Review, 27, 651-677.

Center for Education of Children Overseas (Ed.). (1984). hoshuko karikyuramu kaihatsu no tame no kiso-teki kenkyu [Basic investigative studies for development of hoshuko curriculum]. Tokyo: Center for education of children overseas.

Charmaz, K. (1983). The grounded theory method: An explication and interpretation. In R. M. Emerson (Ed.), Contemporary field research: A collection of readings. Boston: Little, Brown.

Corsaro, W. A. (1981). Entering the child's world: Research strategies for field entry and data collection in a preschool setting. In J. Green \& C. Wallat (Eds.), Ethnography and language in educational settings (pp. 117-145). Norwood, NJ: Ablex.

Editing Committee of the Book on History of [Japanese] Children Overseas. (Eds.). (1991). The history of education for children overseas. Tokyo: Japanese Overseas Educational Services.

Ericson, F. (1973). What makes school ethnography "ethnographic?". Anthropology and Education quarterly, 4(2) 10-19. 
Farkus, J. B. (1983). Japanese overseas children's American schooling experience: A Study of cross-cultural transition. Dissertation Abstracts International, 44 (11), A3365.

Fujisaki, H. (1986). Communication in classrooms. Japanese Journal of Educational Psychology, 34. 359-368.

Gearing, F. \& Epstein, P. (1982). Learning to wait: An ethnographic Probe into the operations of an item of hidden curriculum. In G. D. Spindler (Ed.), Doing ethnography of schooling: Educational anthropology in action. New York: Holt, Rinehart, and Winston.

Geertz, C. (1973). The interpretation of cultures. New York, NY: Basic Books. Gumperz, J. J. (1962). Types of linguistic communities. Anthropological Linguistics, $\underline{4(1)}, 28-40$.

Heath, S. B. (1983). Ways with words: Language, life, and work in communities and classrooms. Cambridge: Cambridge University Press.

Hendry, J. (1986). Becoming Japanese: The world of pre-school child. Honolulu: University of Hawaii Press.

Honigmann, J. J. (1970). Sampling in ethnographic fieldwork. In R. Naroll \& R. Cohen (Eds.), Handbook of method in cultural anthropology. New York: Columbia University Press.

Hoshino, A. (1989). Ibunkakan kyoiku to komyunikaashyon [Intercultural education and communication.] Ibunkakan Kyoiku [Intercultural Education], 3, 4-16 Hymes, D. (1972). Models of the interaction of language and social life. In J. Gumperz \& D. Hymes (Eds.), Directions in sociolinguistics. New York : Basil Blackwell.

Jackson, P. W. (1968). Life in classrooms. New York: Holt, Rinehart, and Winston, Inc. 
Japanese Overseas Educational Services. (1995) Kaigaishijo kyoiku-shisetsu deeta shu: Hoshujugyoko hen. (jo)/Database for overseas educational institution for Japanese children: hoshuko version. (part 1)].

Japanese Overseas Educational Services. (1997, January 1). Tadaima nannin? [How many (overseas Japanese children) are they?]. Kaigaishijo Kyoiku [Education for Overseas Japanese Childrenl, 287, 18-22.

Javidi, A. \& Javidi, M. (1994). Cross-cultural analysis of interpersonal bonding: A look at East and West. In L. A. Samovar \& R. E. Porter (Eds.), Intercultural communication: A reader. Belmont, CA: Wadsworth.

Jorden, E. H. \& Noda, M. (1987). Japanese: The spoken language, part one. New Haven, CN: Yale University Press.

Jorgensen, D. L. (1989). Participant observation. Newbury Park: Sage.

Kirk, J. \& Miller, M. L. (1986). Reliability and validity in qualitative research. New bury Park, CA: Sage Publications.

Kume, T. (1991). Komunikaashyon. [Communication (Studies on overseas Japanese children)]. In Editing Committee of the Book on History of [Japanese] Children Overseas. (Eds.). The history of education for children overseas. Tokyo: Japanese Overseas Educational Services.

Labov, W. (1972). On the mechanism of linguistic change. In J. Gumperz \& D. Hymes (Eds.), Directions in sociolinguistics. New York : Basil Blackwell.

LeCompte, M. D. \& Goetz, J. P. (1982). Problems of reliability and validity in ethnographic research. Review of Education Research, 52, 31-60.

LeCompte, M. D. \& Preissle, J. (1993). Ethnography and qualitative design in educational research (2nd ed.). San Diego, CA: Academic Press, Inc. Lincoln, Y. S. \& Guba, E. G. (1985). Naturalistic inquiry. Newbury Park, CA: Sage Publications. 
Littlejohn, S. W. (1992). Theories of human communication (4th ed.). Belmont, CA : Wadsworth Publishing Company.

Lofland, J. \& Lofland, L. H. (1984). Analyzing social settings: A guide to qualitative observation and analysis. California: Wadsworth.

Lofland, J. \& Lofland, L. H. (1995). Analyzing social settings: A guide to qualitative observation and analysis (3rd ed.). Belmont, CA: Wadworth Publishing Company

Lu, L. (1992) A qualitative case study of Chinese teaching assistants' communication in the U. S. university classroom. Unpublished master's thesis, Portland State University, Portland, OR.

Marshall, C. \& Rossman, G. B. (1995) Designing qualitative research (2nd ed.). Thousand Oaks, CA: Sage Publications.

McCracken, G. (1988). The long interview. Newbury Park, CA: Sage Publications.

Michaels, S. (1981). "Sharing Time": Children's narrative styles and differential access to literacy. Language in Society, 10, 423-442.

Ministry of Education (Eds.) (1994). Kaigai-shijo kyoiku no genjo [Current conditions for the education for overseas Japanese children].

Minoura, Y. (1984). Kodomotachi no ibunka-taiken [Children's intercultural experience]. Tokyo: Shisakusha.

Nakagawa, N. (1989) Exploratory study: Preparation by Japanese parents in the U. S. for their children's reentry to Japan from an intercultural communication perspective. Unpublished master's thesis, Portland State University, Portland, OR.

Nakanishi, A. (1985). Cultural differences between Japan and Western countries perceived by the returnee students and the Japanese parents living in 
Boston. Bulletin of the Center for Education of Children Overseas (Tokyo Gakugei University), 2, 1-24.

Nishida, T. (1996). Communication in personal relationships in Japan. In W. B.

Gudykunst, S. Ting-Toomey, \& T. Nishida (Eds.) Communication in personal relationships across cultures. Thousand Oaks, CA: Sage Publications.

Ohno, Y. (1983). Teachers' verdict of Japanese children in U. S. schools. Bulletin of the Center for Education of Children Overseas (Tokyo Gakugei University), 2 , 79-97.

Patton, M. Q. (1990). Qualitative research and evaluation methods (2nd ed.). Newbury Park, CA: Sage Publications.

Philips, S. (1983). The invisible culture: communication in classroom and community on the Warm Springs Indian reservation. New York, NY: Longman Inc.

Philipsen, G. (1976). Places for speaking in Teamsterville. Quarterly Journal of Speech, 62, 15-25.

Philipsen, G. (1982). The qualitative case study as a strategy in communication The Communicator. 12, 1-24.

Philipsen, G. (1987). The prospect for cultural communication. In Kincaid, D. L. (Ed.), Communication theory from Eastern and Western perspective. New York, NY: Academic Press.

Poole, M. S. \& McPhee, R. D. (1985). Methodology in interpersonal communication research. In M. Knapp \& G. Miller (Eds.), Handbook of interpersonal communication. Beverly Hills, CA: Sage Publications.

Porter, R. E. \& Samovar, L. A. (1994) An introduction to intercultural communication. In L. A. Samovar \& R. E. Porter (Eds.), Intercultural communication: A reader. Belmont, CA: Wadsworth. 
Pratt, D. (1994). Curriculum planning: A handbook for professionals. Orlando, FL: Harcourt Brace College Publishers.

Sakata, M. (1989). Ibunkakankyoiku-comyunikaashyon [Intercultural education communication]. Ibunkakan Kyoiku [Intercultural education]. 3. 4-16

Sarret, C. J. (1984). Observational methods. In W. Gudykunst \& Y. Y. Kim (Eds.), Methods for intercultural communication research. (pp. 205-214). Beverly Hills, CA: Sage.

Sato, G. (1991a). Kyoiku-shisetsu ni okeru kyoiku katsudoh ni kansuru kenkyu [Studies regarding to the educational activities at overseas educational institution for Japanese]. In Editing Committee of the Book on History of [Japanese] Children Overseas. (Eds.). The history of education for children overseas. Tokyo: Japanese Overseas Educational Services.

Sato, G, (1991b) Zaigai-shijo no kyoiku [Education of children overseas]. In Editing Committee of the Book on History of [Japanese] Children Overseas. (Eds.). The history of education for children overseas. Tokyo: Japanese Overseas Educational Services.

Sato, G. (1995). Tenkan-ki ni tatsu kikokushujo-kyoiku [education for returning children at its turning point].

Sato, H. (1991c). Zaigai-shijo kyoiku e no shisaku [Policy for education of children overseas]. In Editing Committee of the Book on History of [Japanese] Children Overseas. (Eds.). The history of education for children overseas. Tokyo: Japanese Overseas Educational Services.

Saville-Troike, M. (1989). The ethnography of communication: An introduction. New York : Basil Blackwell. Schatzman, L. \& Strauss, A. L. (1973). Field research: Strategies for a natural sociology. Englewood Cliffs, NJ: Prentice-Hall. 
Seidman, I. E. (1991). Interviewing as qualitative research: A guide for researchers in education and the social sciences. New York: Teachers College Press.

Sevigny, M. (1981). Triangulated inquiry: A methodology for the classroom interaction. In J. Green \& C. Wallet (Eds.), Ethnography and language in educational settings (pp. 117-145). Norwood, NJ: Ablex.

Sherzer, J. (1975). Ethnography of Speaking. Manuscript, University of Texas at Austin.

The ritual of "sharing time" in a first grade American classroom. (1992, November). Paper presented at the Speech Communication Association convention, Chicago, IL, Nov.

Spindler, D. G. (1959). Transmission of American culture. Cambridge, MA: Harvard University Press.

Spindler, G. D. (1982). Cultural transmission and the "hidden curriculum" [editorial commentary]. In G. D. Spindler (Ed.), Doing ethnography of schooling: Educational anthropology in action. New York: Holt, Rinehart, and Winston.

Spindler, G. D. \& Spindler, L. S. (1982). The American cultural dialogue and its transmission. New York, NY: Falmer Press.

Spradley, J. (1979). The Ethnographic Interview. New York: Holt, Rinehart, and Winston.

Strauss, A. \& Corbin, J. (1990). Basics of qualitative Research: Grounded Theory procedures and techniques. Newbury Park, CA: Sage.

Ting-Toomey, S. (1984). Qualitative research: An overview. In W. B. Gudykunst \& Y. Y. Kim (Eds.), Methods for intercultural communication research. Beverly Hills, CA: Sage Publications. 
Valentine, K. B. (1995). Transcription information for WSCA: Com 509 Qualitative research method in communication. Workshop presented at the Western Communication Association convention. Portland, OR, Feb., 1995.

Watson, K. A. (1975). Transferable communicative routines: Strategies and group identity in two speech events. Language in Society, 4, 53-72.

Woods, P. (1992). Symbolic interactionism: Theory and method. In M. D. LeCompte, W. L. Millroy \& J. Preissle (Eds.), The handbook of qualitative research in education. San Diego, CA: Academic Press, Inc.

White, M. (1988). The Japanese overseas: Can they go home again? New York: The Free Press.

Wilcox, K. (1982a). Differential socialization in the classroom: Implications for equal opportunity. In G. D. Spindler (Ed.), Doing ethnography of schooling: Educational anthropology in action. New York: Holt, Rinehart, and Winston.

Wilcox, K. (1982b). Ethnography as a methodology and its application to the study of schooling: A review. In G. D. Spindler (Ed.), Doing ethnography of schooling: Educational anthropology in action. New York: Holt, Rinehart, and Winston.

Yanagi, T. (1983). Comparative study of Japanese and American teachers treatment of pupil during class. Bulletin of the Center for Education of Children Overseas (Tokyo Gakugei University), 2, 55-77.

Yano, (1990). Kodomo no ibunka-taiken ni kansuru gakusai-teki kenkyu. [Academic research regarding (overseas Japanese) children's intercultural experience.] Tokyo: Sozosha.

Yokogawa, M. (1990) Bunka-teki dohka to shite no kyoiku [Education as an cultural assimilation]. Ibunkakan Kyoiku [Intercultural Education], 3, 112-127 


\section{Appendix A \\ Correspondence with The Research Site Regarding Field Entry}




\section{APPENDIX. A-1}

A Letter to the Chair of the Board of Education [Japanese Original]

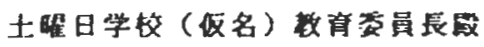

括颉

私岋林ートシンド州立大学のスピーチ・コミュニクーション学部の修士棵程で勉強致

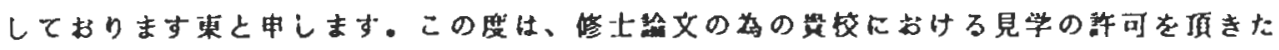
くま便りさせて頂いております。

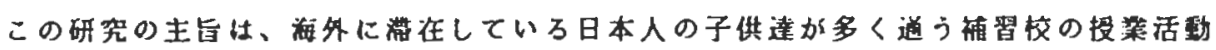
を道じて、子供連加との榢なコミュニケーション・スタイルを身につけていっているかを 知るためのもので。

照在海外に在留する日本人子女の数は全世然て約 5 万人にものほります。北米(カナ

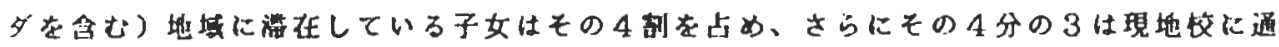

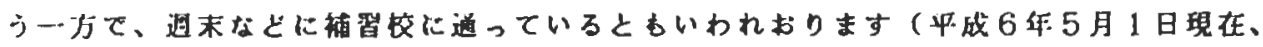

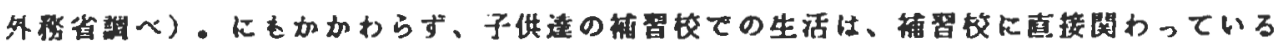

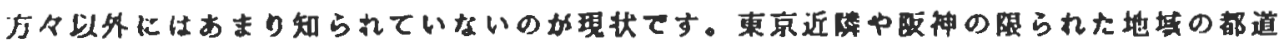

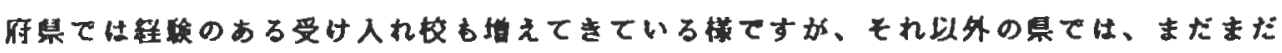

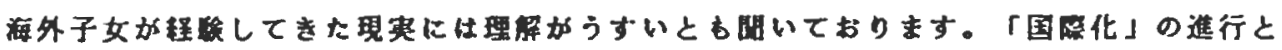

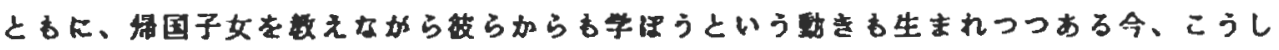

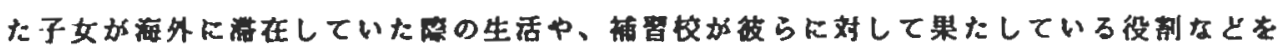
理雕する事加、加ってない汪ど重要になっていると管します。

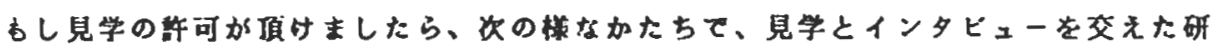

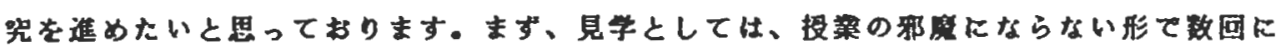

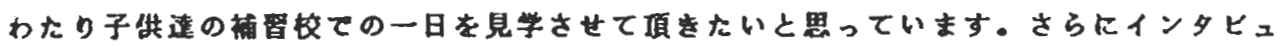

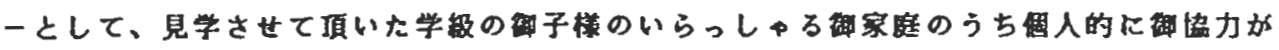




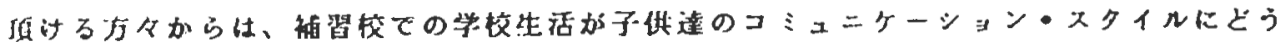

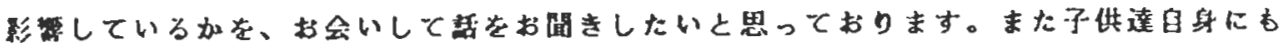

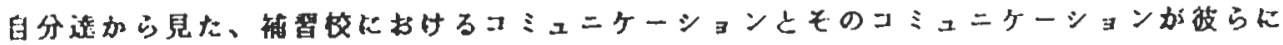

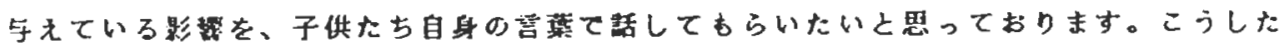

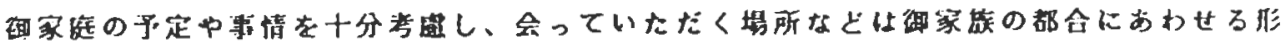
で決定したいと考えてかり志す。

珐の秘笑の中て使われる研究方法、つまり見学とインタビュ一は、これまでいろい

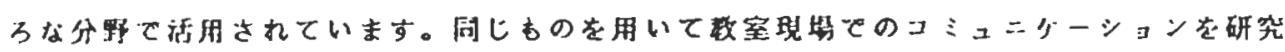
したすのには、Heath(1983),Philips(1993)などが举げられます。Heath(1983)が1970年

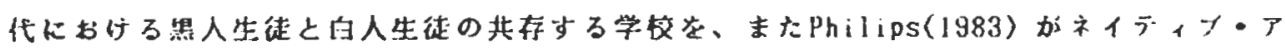

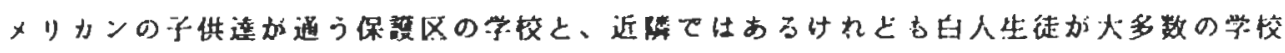

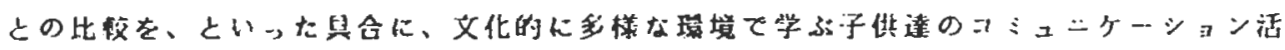

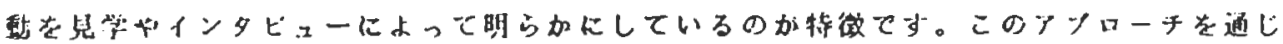

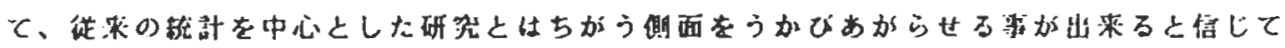
おります。

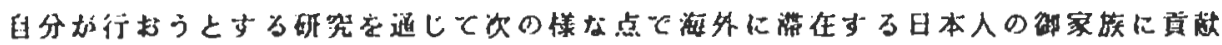

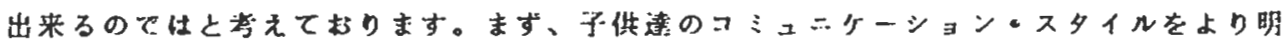
らかにする事によって、今後より子供たち自身のニースにあった受け人机フロクラムを作

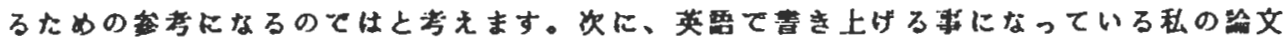

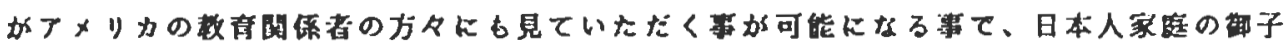

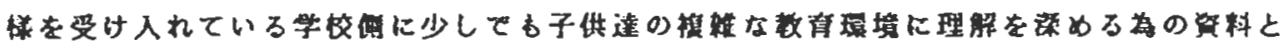

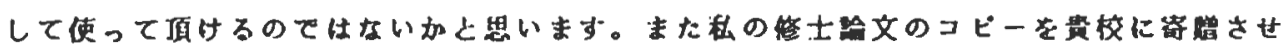

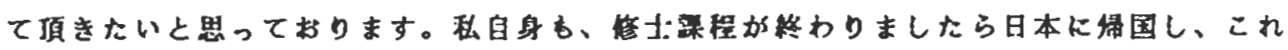

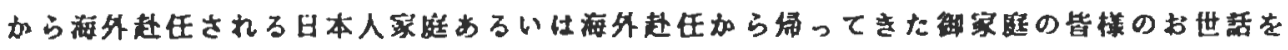

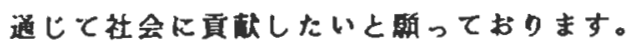

最後になりましたか、この研究のための見学を是非㳯可して頂けます样重かてお預い 
申し上げます。侪研究に当たってはメーサン・ボールせン教投が指導教官になって下さ

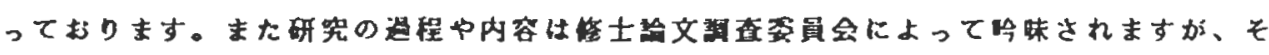

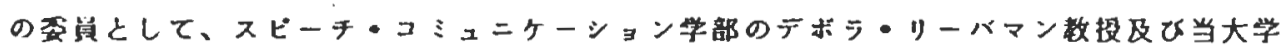

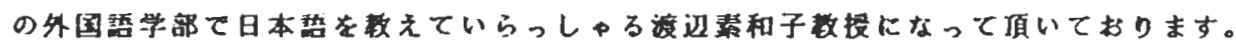

御畦力を心加ら感致します。

具

束 䗷子

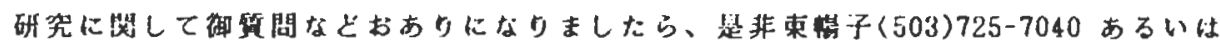
スーザン・ホールセン(503)72らー3544まで敷速䊀下さい。 


\section{APPENDIX. A-2}

\section{A Letter to the Chair of the Board of Education [Translation]}

December 1, 1995

Dear Chairperson of the Board of Education at JSS,

My name is Nobuko Higashi. I am a graduate student in the Speech Communication Department at Portland State University. I am writing you to request permission to observe classrooms in your school for my MA thesis research project. The purpose of this research is to better understand the ways in which children come to learn communication styles through the interaction in hoshuko classes where many overseas Japanese children gather to learn.

Currently there are about 50,000 Japanese children who are living overseas. Of these, about 40 percent of them reside in North America (including both the United States and Canada), and about 75 percent of them go to hoshuko on weekends and/or after attending regular classes in the host country. Although many Japanese children attend hoshuko, little is known about the children's experience in these classes except for those who are directly involved in hoshuko education. Although the number of ukeire-ko [the schools that have programs to accept children returning from overseas] is growing in Tokyo and Osaka, current research suggests that there is still little understanding among educators in other geographical areas about the overseas experiences of these children. Fortunately, There is newly-developing interest in and concerns about returning Japanese children among educators in order that they may help the children readjust to school life in Japan on their return from overseas. I feel that the desire is growing among such educators to understand the lives of those overseas Japanese children including their lives in hoshuko, and that understanding the roles that hoshuko is playing for those children is more important than ever.

If I am permitted, I would like to conduct my study utilizing observations and interviews. I would like to observe the daily activities of the classes at hoshuko and would do so in a way that would least disturb the class. I would like to conduct interview with parents of the children in the class that I observed, those who are willing to cooperate with me. I would like to ask these parents to tell me how, if at all, they think the school life at hoshuko has affected and is affecting their children's ways of communication. With their parents' permission, I would like to ask the students about their own perceptions of the affect on their overall communication styles of interactions with their teachers and peers at hoshuko. I am fully aware that many of the students and their families have very busy schedules, so l will try my best to adjust my schedule in terms of place and time for the interviews.

The methodology that I am using for this study -- observation and interviewing -- is used in various field of research. I can cite studies by Heath (1983) and Philips (1983) as studies which utilize the same methodology as my own and with a focus on communication phenomena in the classroom setting. Both studies looked at schools in a culturally complex environment. For example. Heath (1983) looked at a school in the 1970's when African-American students and Caucasian students had just started to study side by side. Philips (1983) compared classrooms in a school for Native Americans on reservations with classrooms in a nearby school where the majority of 
participants were Caucasian. I believe that using this specific method and focus will allow me to delineate the aspects that are different from those described through existing, statistic-oriented studies.

I hope I can contribute to the Japanese families who stay overseas in several ways. I believe the results of this study can contribute toward developing a program for the overseas Japanese children on their return to Japan that would address the needs of the children. I also believe that my study will be useful for those U. S. educators who interact with overseas Japanese children in their schools, as my completed study will be available in English. I will make available to you a copy of my thesis. As for myself, after I finish my Master's program and go back to Japan, I want to work with Japanese families who will be assigned overseas, or those families who have come back from their assignments overseas.

This study is conducted under the supervision of Susan Poulsen Ph. D. in the Speech communication Department. The process and content of the study will be examined by the thesis committee, in which Dr. Poulsen serves as the chairperson. The other members of the committee include Devorah Lieberman Ph. D. in the Speech Communication Department, and Suwako Watanabe Ph. D. who teaches Japanese in the Foreign Language Department.

Thank you for your review and consideration of my request. I will be happy to answer any questions you might have and appreciate your support in this project.

sincerely yours,

Nobuko Higashi

If you have any questions about this study, please contact Nobuko Higashi at (503)725-7040 or Dr. Susan Poulsen at (503)725-3544. 
Appendix B

Informed Consent 


\section{APPENDIX B-1}

Letter of Consent (for student participants)

Dear Student and Parent/Guardian:

I am currently a graduate student in the Speech Communication Department at Portland State University, Portland Oregon, studying the nature and the meaning of communication patterns in the hoshuko setting. This study is part of the requirement for my master's degree. The goal in interviewing your child/ren about their perceptions of communication patterns in their classroom is to better understand classroom communication in hoshuko from the children's point of view.

Each interview will last 30 to 60 minutes. It will be scheduled at your child/ren's convenience and will take place at safe and comfortable locations. The information provided will be held confidential. The names of your child/ren will not be identified in the findings. Your child/ren will have the right to refuse to answer any question which they do not wish to answer or withdraw from the process in case that they do not feel like participating.

Your consent is part of the approval process as each young participant and parent(s)/guardian(s) gives permission in writing before taking part in the study. I hope that you will agree to help in this study, and I would like to thank you in advance for your cooperation. Enclosed is a consent form for your signature.

If you have any questions about this study, please contact Nobuko Higashi at (503)725-7040 or Dr. Susan Poulsen at (503)725-3544. If you experience any problems that are the result of your participation in this study, please contact the Chair of the Human Subjects Research and Sponsored Projects, 105 Neuberger Hall, Portland State University, (503)725-3417.

Thank you very much for your participation.

Sincerely

Nobuko Higashi

Graduate Student

Speech Communication Dept.

Portland States University, Portland, OR. 97201

Susan B. Poulsen

Chairperson, Thesis Committee

Speech Communication Dept.

Portland States University, Portland, OR. 97201 


\section{APPENDIX B-2}

INFORMED CONSENT (for student participants and their parents)

Code Number:

I, informant in the research project on the classroom communication at the hoshuko setting conducted by Nobuko Higashi under the supervision of Susan Poulsen, Ph. D.

It has been explained to me that the purpose of this study is to better understand classroom communication in hoshuko from children's point of view.

I understand this study demands my time spent in interviews. I may not receive any direct benefit from participation in this study, but my participation may help to increase knowledge which may benefit others in the future.

Nobuko Higashi has offered to answer any questions I may have about the study and what is expected of me in this study.

I have been assured that my identity and information I give during the interviews will be kept confidential, and that the names of all people in the study will be confidential as well.

I also understand that I am free to withdraw from participation in this study at any time without affecting my relationship in anyway with the hoshuko your children attend or Nobuko Higashi.

I have read and understand the foregoing information and agree to participate in this study.

Child/ren's Signature:

Date:

Date:

Parent/Guardian:

Date:

If you have any questions about this study, please contact Nobuko Higashi at (503)725-7040 or Dr. Susan Poulsen at (503)725-3544. If you experience any problems that are the result of your participation in this study, please contact the Chair of the Human Subjects Research and Sponsored Projects, 105 Neuberger Hall, Portland State University, (503)725-3417. 


\section{APPENDIX B-3}

Letter of Consent (for the teacher)

Dear teacher:

I am currently a graduate student in the Speech Communication Department at Portland State University, Portland Oregon, studying the nature and the meaning of communication patterns in the hoshuko setting. This study is part of the requirement for my master's degree. The goal in interviewing you about your perceptions of communication patterns in hoshuko classroom is to better understand classroom communication in hoshuko from your point of view.

Each interview will last 45 to 75 minutes. It will be scheduled at your convenience and will take place at safe and comfortable locations. The information provided will be held confidential. Your name will not be identified in the findings. You will have the right to refuse to answer any question which you do not wish to answer or withdraw from the process in case that you do not feel like participating.

Your consent is part of the approval process as each participant gives permission in writing before taking part in the study. I hope that you will agree to help in this study, and I would like to thank you in advance for your cooperation. Enclosed is a consent form for your signature.

If you have any questions about this study, please contact Nobuko Higashi at (503)725-7040 or Dr. Susan Poulsen at (503)725-3544. If you experience any problems that are the result of your participation in this study, please contact the Chair of the Human Subjects Research and Sponsored Projects, 105 Neuberger Hall, Portland State University, (503)725-3417.

Thank you very much for your participation.

Sincerely

Nobuko Higashi

Graduate Student

Speech Communication Dept.

Portland States University, Portland, OR. 97201

Susan B. Poulsen

Chairperson, Thesis Committee

Speech Communication Dept.

Portland States University, Portland, OR. 97201 


\section{APPENDIX B-4}

INFORMED CONSENT (for adult participants)

Code Number:

$\mathrm{I}$, informant in the research project on the classroom communication at the hoshuko setting conducted by Nobuko Higashi under the supervision of Susan Poulsen, Ph. D.

It has been explained to me that the purpose of this study is to better understand classroom communication in hoshuko from participants' point of view.

I understand this study demands my time spent in interviews. I may not receive any direct benefit from participation in this study, but my participation may help to increase knowledge which may benefit others in the future.

Nobuko Higashi has offered to answer any questions I may have about the study and what is expected of me in this study.

I have been assured that my identity and information I give during the interviews will be kept confidential, and that the names of all people in the study will be confidential as well.

I also understand that I am free to withdraw from participation in this study at any time without affecting my position at your hoshuko or my relationship with Nobuko Higashi in anyway.

I have read and understand the foregoing information and agree to participate in this study.

Participant Signature:

Date:

If you have any questions about this study, please contact Nobuko Higashi at (503)725-7040 or Dr. Susan Poulsen at (503)725-3544. If you experience any problems that are the result of your participation in this study, please contact the Chair of the Human Subjects Research and Sponsored Projects, 105 Neuberger Hall, Portland State University, (503)725-3417. 


\title{
APPENDIX B-5
}

Letter of Consent (for the teacher)

\author{
給文研究についてのこ説明
}

研究者氏名：

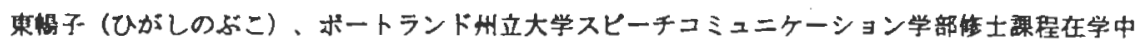

研究主避 :

土曜日学校（仮名）に通う子供たちのコミュニケーション・スタイル

研究目的 :

土搉日学挍に通う子供たちが、先生や友達とのコミュニケーションを通じいろいろなことを学で

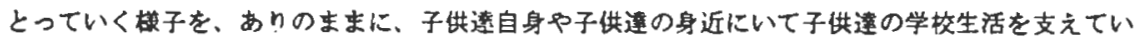
る人々の䙓点に打来るだけ近い形でとらえ、理解する。

\section{インタビューに関して}

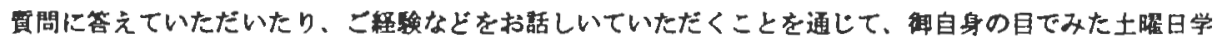

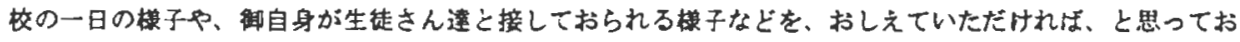
ります。

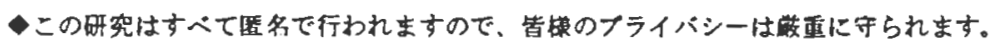

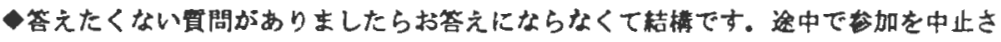
れてもかまいません。

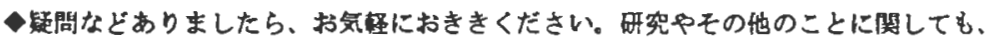
喜んでお答えしたいと思います。
東楊子
スーザン・ポールセン（ポートランド州立大学数投）
( 503$) 725-7040$
波辺素和子（同大学数投）
( 503 ) $725-3544$
$(503) 725-5284$

このような研究の常として、上即の事柄を理解した上で研究にも加するという旨を書面にサインしていた だくことしなっております。お手数をおかけしますがよろしくおねがいもうしあげます。

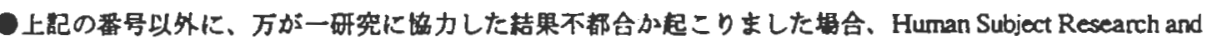
Sponsored Projects (Address: 105 Neuberger Hall, Portland State University)に問い合わせていただけます。 


\title{
APPENDIX B-6
}

Letter of Consent (for parents of hoshuko students)

\author{
赔文研究についてのご説明
}

研究者氏名:

東蜡子（ひがしのぶこ）、本ートランド州立大学スピーチコミュニケーション学部偖士課程在学中

研究目的:

土樶日学校（䛀名）に通う子供たちが、先生や友違とのコミュニケーションを通しいろいろなこと

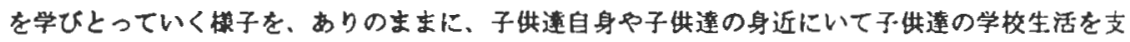
えている人々の覞点に出来るだけ近い形でとらえ、理解する。

\section{インタビューに関して}

いくつかの貫問に答えていただくことを通じて、お子模には土㫿日学校を中心とした子供としての日常の

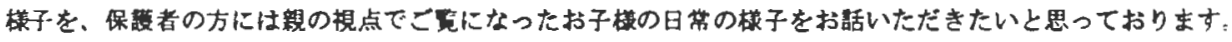

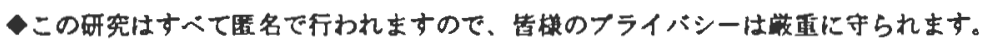

け答えたくない貫問がありましたらお答えにならなくて耛粠です。途中です加を中止さ れでもかまいません。

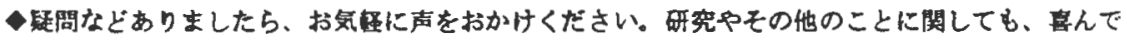
お答えしたいと思います。
東锝子
( 503 ) $725-7040$
スーサン・ボールセン（ボートランド州立大学数授）

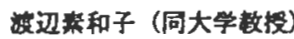
( 503 ) $725-3544$
( 503 ) $725-5284$

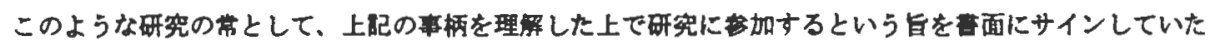
だくことしなっております。また、お子模が末成年者のため、保萑者の方のサインがさらに必要となります。 お手数をおかけしますがよろしく赫がいもうしあげます。

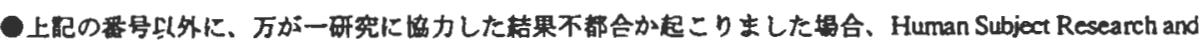
Sponsored [rojects（Address: 105 Neuberger Hall, Portiand State University) に問い台わせていただけます。 


\section{APPENDIX B-7}

Letter of Consent (for student participants)

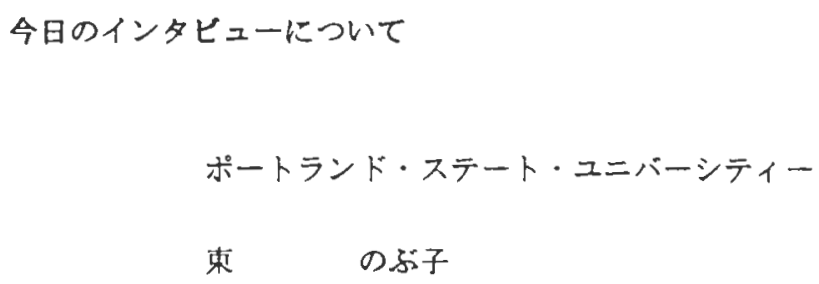

今日は、わたしとおはなしするじかんをとってくれて ほんとうにどうむありがとう。 これからするインタビューについて少しせつめいします。

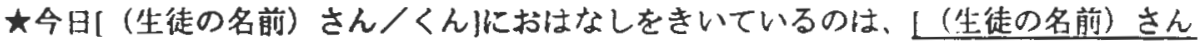
くくん夙土曜旦学校でほかのおともだちといっしょにいろんなことをならっているよ うすをもっとよくしるためです。

|(生徒の名前)さん/くんしししんのめでみて、こころでかんじた学校のようすがしりた いので、「もう東先生はしってろにちがいない。」と括うようなことでも、いろいろと はなしをしておしえてくれるとうれしいです。

まちがったこたえというのはありませんから、おもったとおりをはなしてください。

ネ[（生徒の名前）さん/くん]がはなしてくれたここは、「ろんぶん」というながい文し ょうにかくことになりますが、インタヒューのあいたにおしえてもらったことを、かって にほかのひとにはなしたりすることはありません。

Łもし、はなすのがいやだなとか はずかしいなとかいうしつもんがあったら、おしえ てくだい。そういうしつもんにはこたえなくていいです。きいたことがわかりにくかっ たら、しんばいせずにきいてください。

れなにかのりゅらでとちゅ5でやめたくなったときにも、おしえてください。むりして つゔけることはしません。

できろだけ たのしいじかんにしたい、とおもっています。よろしくね。 


\section{APPENDIX B-8 \\ INFORMED CONSENT (for the teacher)}

ポートランド州立大学スピーチコミュニケーション学部

俥究咕力承带苦

私、

は、東粕子の

論文研究に劫力いたします。

哩本人のサイン： 日付

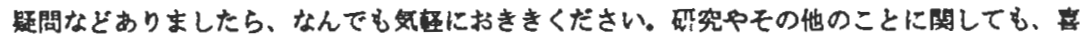
んで㧍答えしたいと思います。

東埇子

( 503 ) $725-7040$

スーザン・ボールセン（ポートランド州立大学數提

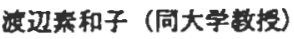

( 503 ) $725-3544$

Human Subject Research and Sponsored Projects

$\left(\begin{array}{lll}5 & 0 & 3\end{array}\right) 725-5284$

$\left(\begin{array}{lll}5 & 0 & 3\end{array}\right) 725-3417$ 


\section{APPENDIX B-9}

INFORMED CONSENT (for students participants and their parents)

$$
\text { ポートランド州立大学スピーチコミュニケーション学部 }
$$

研究她力承諸香

私 (達) は、取啺子の

敲文研究に協力いたします。

お子棣のサイン： 日讨

保藤者の方のサイン： 日付

钘問などありましたら、なんでも気虽におききください。研究やモの他のことに関しても、喜 んでお答えしたいと思います。

東睡子

スーザン・ボールセン（ボートランド州立大学数授）

漠辺案和子(同大学数授)

Human Subject Research and Sponsored Projects
(503) $725-7040$

( 503 ) $725-3544$

( 503 ) $725-5284$

( 503 ) $725-3417$ 


\section{Appendix C \\ Correspondence with The Family of The Students Regarding The Interview}




\begin{abstract}
APPENDIX. C
A Letter to the family of the Mrs I's students to explain the general purpose of the research and to request their participation
\end{abstract}

士时学学校（仮名）旧 1 年 2 組

1996 年 6 月 1 日

(1995 年度) の保蘘者の皆様

拝要

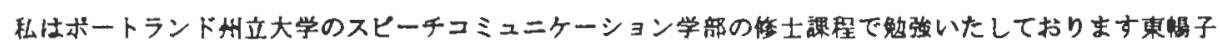
と申します。昨年I 先生（仮名）の数室におしゃましていた際には、いろいろ大変お世話になりました。皆 槏にはいかがお過こしでしょうか。

私は、理在、スーザン・ボールセン教投の指革のもと、お不栟方のように土曜日学校に通っている生徒達 が土曜日学校で先生や友達とのコミュニケーションを通して梾々なことを学んでいる㥞子について、研㠰を おこなっています。䑚がこのような研究テーマをえらんだ背累には、大学生活など公乱にわたりアメリカの 文化の影要を受けながら生活している反面、皆棁を含めたこちらの日本人の方とのつきあいなど日本文化に

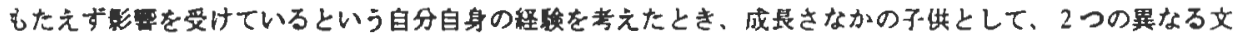

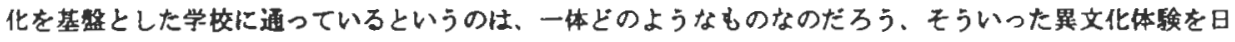
々の生活としている子供たちの現奏をできるだけ理解したいと考えるに至ったということがあります。

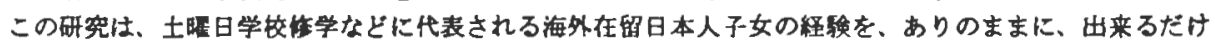

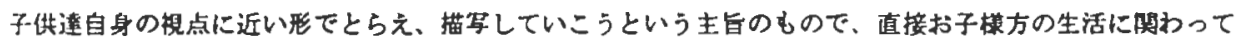

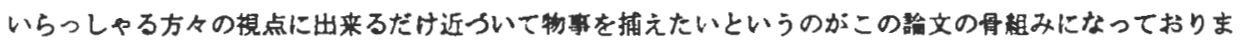
す。そのため、当事者であるお子樴方、また、保護者の皆粎からお話をお何いするということが大变重要に

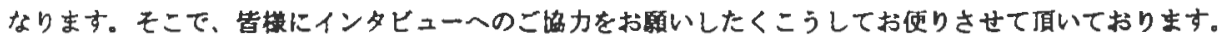

インタビューと申しましても決してかたくるしい内容のものではなく、保誉者の方、また、お子様方に個

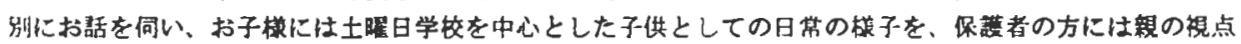

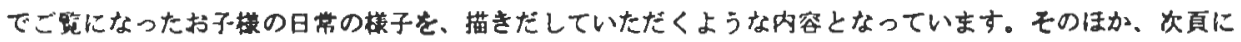

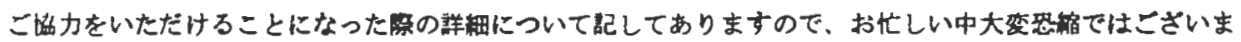

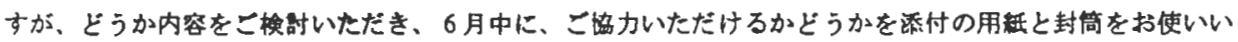
ただくかお電話（東物子503ー725－7040）でこ連絡くださいます㥞よろしくお制い申し上げます。

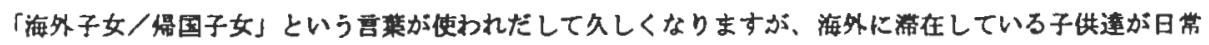

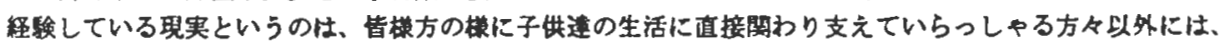
あまり知られておりません。そのため、この文は、現地校の先生方や㷌国した祭の受け入れ湖など必ずし

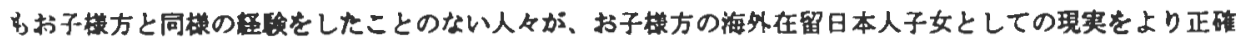
に理解するために、少しです投立つのでは、と䫏っております。

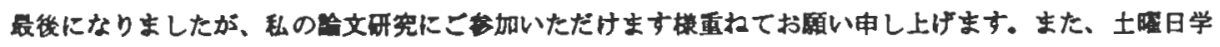
校でもたひたひお会いすることもあるかと思いますが、今挠ともどうかよろしくお碩い申し上げます。

敏具

東 晿子

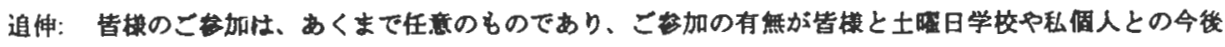

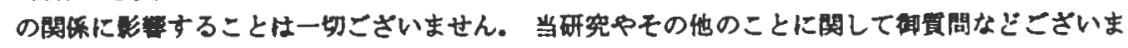

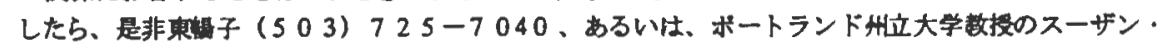

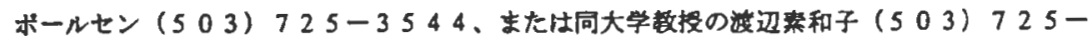
5284 までご傻ください。 


\section{インタビューに関する群盘}

形式:

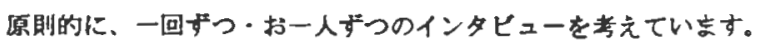

所要時間 :

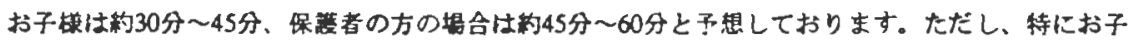
模など、十分に配虑をして無理のかからない上うに時間を決めるつもりです。

垛所・時間：

皆枇方のこ都合にあわせる形で決定したいと考えております。

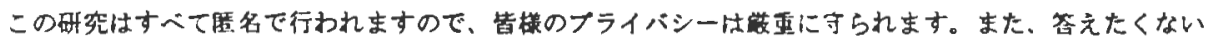

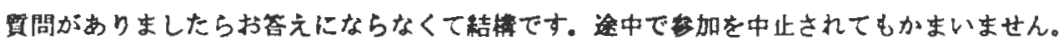

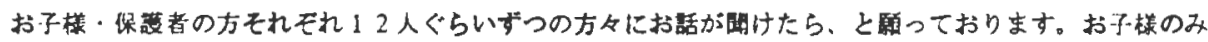

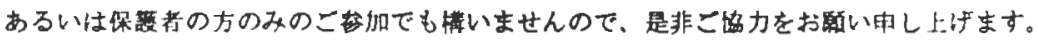

キリトリセン

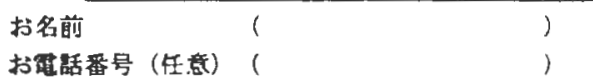

該当する郡畧に丸をしてください。

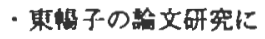

A. 妶力してもよい.

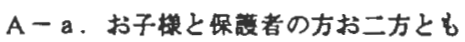

A 一 b.お子茟のみ

$\mathrm{A}-\mathrm{c}$ ，保淛者の方のみ

B. もっと詳しく内容を知ってから決めたい。

C. 加しない、あるいは出来ない.

こ好力を媔くにあたって、あるいは、こ決定をされるにあたって、䦎などありましたら、西話等で喜ん

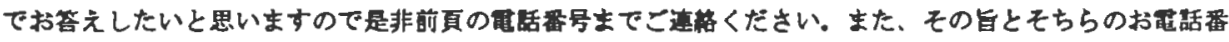
号とを即即入いただけれは、こちらからお雪話をさしあげます。

[こ貫問・こ意見その地気が付かれたことがありましたら下の空らんに制自由にお雪きください。]

贵重なお時間どうもありがとうこさいました。 
Appendix D

Interview Guides 


\section{APPENDIX D-1}

Interview Guide for the students attending hoshuko

\section{1.}

1. (Please) Describe a typical day (events) on the day you go to hoshuko? (sequence; time)

2. Who usually come to hoshuko?

(participants)

3. (Please) Describe hoshuko classroom/school for me. (scene/setting)

a. What is there? etc.

b. What is not there, if compared to your U.S. classroom/school?

4. What things do you do that are related to hoshuko? (scene)

i. e. homework, related events [friendship day], etc.

5. What language do you use at hoshuko? (Instrumentality [message form]) -What language do you use at places other than hoshuko?

i.e. At American school, at home (with parents, with siblings, etc.), with friends/acquaintances (Japanese/non-Japanese)

6. What do you think you learn at hoshuko? (Ends)

a)-Had you heard about hoshuko before you entered school here (or came [for those who start coming at the middle of the school year) the school?

-What kinds of things?

-What did you think then? 
(6. continued, probe b) )

b)-was it turned out to be what you thought it would?

if so, how so?

if not, how not so?

7. In your words, why do you go to hoshuko?

(end)

8. How do you feel while you are at hoshuko?

(key)

9. what kind of things do you think you are:

-supposed to do in hoshuko?

(end)

-allowed to do in hoshuko?

-NOT allowed to do in hoshuko/not supposed to do in hoshuko?

(norms)

II.

1. ask for comments, suggestions and questions.

2. Thank for their time. 


\section{APPENDIX D-2}

Interview Guide for the teacher(s) at hoshuko

I.

1. (Please) Describe a typical day (events) on the day you go to hoshuko? (sequence)

2. Who (usually) come to hoshuko? (participants)

3. (Please) Describe your classroom/school for me. (scene/setting)

a. what is there? etc.

4. What things do you do that are related to hoshuko? (possibly as "scene")

i. e. preparation for the classes, related events [friendship day], etc.

5-1. - What language do the students use at hoshuko? (Instrumentality

[message form])

5-2. -What language do you use at hoshuko? (Instrumentality [message form])

-What language do you use at places other than hoshuko?

i.e. At the U.S. school where she teaches, at home (with family members), with friends/acquaintances (Japanese/non-Japanese)

6-1. What kind of things do the students talk about while they are in school -in what language? 
7. What do you think the students learn at hoshuko?

(Ends)

8. In your words, why do the students come to hoshuko?

(end)

9. How do you feel while you are at hoshuko?

(key)

-How would you describe the atmosphere in the hoshuko classrooms?

in your classroom?

10. what kind of things do you think the students are:

-supposed to do in hoshuko? (end, rather?)

-allowed to do in hoshuko?

-NOT allowed to do in hoshuko/not supposed to do in hoshuko? (norms)

II.

1. ask for comments, suggestions and questions.

2. Thank for their time. 


\begin{abstract}
APPENDIX D-3
Interview Guide for the parents of the students attending hoshuko
\end{abstract}

I.

1. What are the things that your children do at home that are related to hoshuko activities?

2. What are your observation of ways in which your children communicate with other family members (or friends; peers)? -at home/outside school (in public) etc.

3. What do you think about having a hoshuko right here in Portland?

4. What important things do you think your child/ren learn by going to such a school?

5. What kind of change have you noticed since ...

-your family came over to the United States?

-your children started to go to hoshuko?

6. How do you manage balancing doing well in the U.S. school while maintaining the Japanese ways of speaking and so forth? I have heard it is sometimes very hard to balance the two.

II.

1. ask for comments, suggestions and questions.

2. Thank for their time. 


\section{Appendix E \\ Diagram of School Setting}


APPENDIX. E

Diagram of School Setting

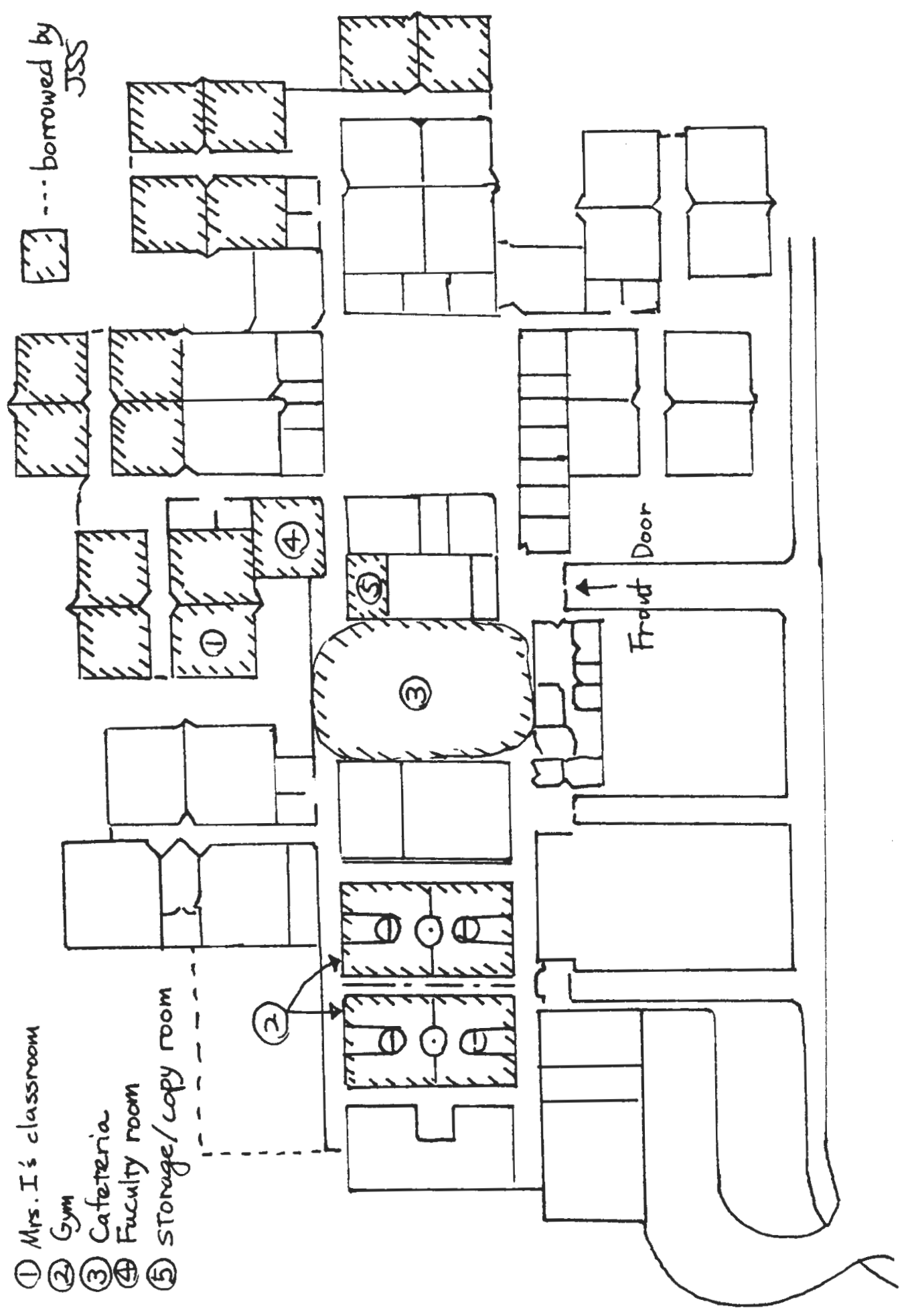

